\title{
Primera parte \\ La modernidad metropolitana
}

Victor Hugo Torres Dávila

\section{SciELO Books / SciELO Livros / SciELO Libros}

TORRES DÁVILA, V. H. La modernidad metropolitana. In: Hegemonías y subalteridades urbanas: la configuración metropolitana de Quito [online]. Quito: Universidad Andina Simón Bolívar, Sede Ecuador; Editorial Abya-Yala, 2020, pp. 55-211. Investigación Decolonial series, n. 4. ISBN: 978-9978-10-4569. http://doi.org/10.7476/9789978105757.0003.

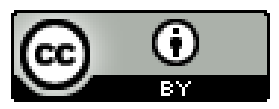

All the contents of this work, except where otherwise noted, is licensed under a Creative Commons Attribution 4.0 International license.

Todo o conteúdo deste trabalho, exceto quando houver ressalva, é publicado sob a licença Creative Commons Atribição 4.0.

Todo el contenido de esta obra, excepto donde se indique lo contrario, está bajo licencia de la licencia Creative Commons Reconocimento 4.0. 
Primera parte

\section{LA MODERNIDAD METROPOLITANA}



La formación del DMQ es un proceso espacial, institucional, normativo, urbanístico y cultural, cuyos orígenes se enlazan a su crecimiento, cuando la heredada ciudad colonial, asiento de la economía agraria y comercial de las familias aristocráticas, de una reducida clase media conformada principalmente por empleados públicos, y geográficamente sitiada por haciendas y comunas ancestrales, empezó su tránsito hacia la modernidad. Se transformó el poder local, junto con complejas dinámicas económicas, territoriales y societales en las que surgieron nuevas formas de mediación social.

En pocos años la ciudad experimentó cambios sustantivos en su sociedad y geografía. La tradicional villa colonial pasó de su originaria forma radial concéntrica, propia de una urbe de centralidad cívica y religiosa, a una longitudinal y policéntrica provocada por el crecimiento urbanístico. El emplazamiento de nuevas industrias, empresas comerciales e inmobiliarias, implantó desordenadas dinámicas de uso y ocupación del espacio urbano y su área de influencia; estimuló el desbordamiento de la ciudad desde la meseta de Quito a los valles orientales circundantes y las planicies de los extremos norte y sur, conformando una extensa "mancha urbana" constituida por el denominado "hipercentro" y cinco centralidades dispersas en el territorio metropolitano, consolidada como el núcleo espacial de la economía y el poder regional.

Grosso modo fue un proceso desencadenado en la segunda mitad del siglo XX y que continúa en las primeras décadas del nuevo siglo, en el que cabe diferenciar entre la expansión territorial metropolitana y su institucionalización como gobierno local, dada a comienzos de los años 1990, cuando se adoptó el régimen de distrito metropolitano y empezó la conversión administrativa, territorial y urbanística conjuntamente con la consolidación de la región centro norte de la que Quito ha sido su centro referencial. El crecimiento metropolitano y su institucionalización tienen como trasfondo cultural el sino de la modernidad capitalista, el deseo compartido entre sus habitantes de asemejarse a las grandes metrópolis occidentales, en las que prima el impulso a la libertad individual en un mundo competitivo y global. 
La explicación cultural del proceso metropolitano de Quito implica desplazarse entre las distintas escalas de su geografía urbana y regional. Involucra a la región económica y a la ciudad compacta en una escala meso, relacionada con el cantón Quito convertido en distrito metropolitano. La ciudad y su área de influencia, como se verá, están articuladas a las dinámicas económicas de un territorio mayor que es la región de la Sierra centro norte del país.

La adopción del distrito metropolitano es la continuidad del proceso territorial de expansión de los poderes regionales, por lo que su normativa y las asertivas decisiones del gobierno municipal fueron un acto de hegemonía cultural de las élites capitalinas. La consecuente conversión institucional hacia el gobierno metropolitano, más allá de la compleja administración de los servicios públicos de una ciudad en expansión, proyectó promesas de orden urbano en dirección a la consolidación del distrito metropolitano como núcleo de la economía regional. 


\section{Capítulo I}

\section{LA IMPLANTACIÓN METROPOLITANA DE QUITO}

No es fácil establecer con claridad las relaciones entre la ciudad compacta de Quito y la región de la que forma parte, especialmente cuando se busca comprender las interacciones culturales que irradian más allá de su área de influencia inmediata, la que administrativamente se enmarca en el cantón del mismo nombre. En parte debido a que el carácter regional de la capital se fraguó con el paso del tiempo, mediante mutaciones de forma, funciones y alcance respecto al país, el Estado y la propia ciudad. En parte también a que el municipio quiteño, si bien se debe a la ciudad, ha sabido beneficiarse del Estado nacional por su cercanía con los poderes regionales.

Lo metropolitano es el signo moderno, contemporáneo, que adquirió esta antigua interacción regional; su comprensión supone reconocer el proceso metropolitano iniciado en los años 60 del siglo XX, diferenciar la coyuntura en la que se adoptó la institucionalidad metropolitana a comienzos de la década de los 90 y, dentro de ella, el simbolismo jerárquico en las decisiones municipales sobre el devenir público de la ciudad.

Empezamos este primer capítulo analizando el marco espacial, institucional y normativo con el que se implantó el DMQ, poniendo énfasis en las narrativas culturales y las simbologías del poder local como expresiones jerárquicas del orden social de la ciudad, con el que se configuró el dispositivo metropolitano.

El capítulo está organizado en tres secciones. La primera reseña la matriz histórica de los poderes regionales que configuraron a la capital del país como una ciudad-región, que desembocó en una formación metropolitana, con lo que las principales dinámicas de la urbe se explican en buena medida por su inserción regional. 
La segunda sección examina los fundamentos simbólicos inmersos en el proyecto de DMQ, el que fue debatido y aprobado en el Cabildo Municipal en los meses de junio y julio de 1990.

Y la tercera sección interpreta el horizonte cultural proyectado con la normativa metropolitana aprobada en 1993, y que consolidó el curso de la modernidad colonial de la ciudad.

\section{La matriz de los poderes regionales}

Quito es la única ciudad metropolitana de Ecuador que, en esa condición, se encuentra inmersa en un área de influencia regional, cuyas funciones políticas, económicas y culturales se intercalan con los contornos geográficos y las demarcaciones administrativas. En páginas anteriores decía que figurativamente hay tres ciudades superpuestas: el Quito urbano o la ciudad compacta, el Quito metropolitano o el área de expansión de la ciudad, y el Quito región que enlaza una geografía económica de mayor alcance. Los tres solapamientos espaciales refieren a un territorio con articulaciones locales e interacciones regionales, en un aparente ordenamiento territorial moderno, pero en realidad es un proceso espacial que se remonta al pasado, incluso antes del período colonial.

El historiador Galo Ramón Valarezo (1992), en su estudio sobre lo que denomina el "espacio de Quito", explica la configuración territorial que encontraron incas e ibéricos en lo que hoy es la ciudad de Quito; arguye que hubo tres distintas denominaciones espaciales:

En primer lugar, hablaremos de la "Llajta de Quito" para referirnos al pequeño espacio geográfico que fue luego "la ciudad" en la época colonial o el centro de Quito en la referencia actual; en segundo lugar, usaremos la idea de "hoya de Quito" para referirnos a la cuenca del río "San Pedro-Guayllabamba", lo que grosso modo, en la época colonial, fue designado como "Quito y sus cinco leguas" y en la designación actual como "Quito metropolitano"; y en tercer lugar, nos vamos a referir a la "región extensa de Quito", "los términos de Quito" o "el gran Quito", cuando necesitemos hablar del espacio que aproximadamente hoy comprende las provincias que se ubican entre Chimborazo e Imbabura. (31) 
Se trata de un proceso histórico de continuidad espacial en la configuración del área de Quito pues, según Ramón Valarezo (1992, 32), las tres denominaciones se usan sin distinción en las "fuentes documentales" cuando aluden a los disímiles procesos espaciales y culturales acaecidos en este lugar antes de la presencia inca e ibérica, provocando "confusiones" que han "enturbiado" una mejor comprensión de esta área. De las distintas interpretaciones que se han ensayado sobre el Quito prehispánico, dice Ramón Valarezo, la más fundamentada se refiere a que era un territorio de articulaciones locales, con "diversos señoríos no unificados" que habían montado afinidades enlazadas en un núcleo de articulación e intercambio interregional que más tarde fue la ciudad colonial (32). Así, un territorio de articulaciones locales con alcance regional está en el origen de la ciudad de Quito.

Contemporáneamente, la ciudad compacta se corresponde con la delimitación municipal de área urbana, aunque varias parroquias rurales se encuentran en una franja gris de solapamientos urbano-rurales, en la que están emplazados los barrios residenciales, áreas comerciales, productivas, las sedes de las instituciones públicas del Gobierno central y las actividades burocráticas derivadas de su condición de capital del país. El área metropolitana, a su vez, corresponde a la demarcación de distrito metropolitano del cantón Quito, y al perímetro de intervención administrativa del gobierno municipal.

El espacio de influencia regional, en cambio, abarca varios cantones y provincias de la denominada Sierra centro norte, incluyendo ramificaciones periféricas hacia la Costa y la Amazonía. Son tres ámbitos de acción económica y política con distintos radios de influencia que inciden en la expansión urbana de la ciudad, y explican su conversión a distrito metropolitano como continuidad, en la modernidad, de una histórica formación regional.

La ciudad propiamente dicha, lo que se conoce como la ciudad compacta y sus áreas suburbanas, no solo es el hábitat de una compleja y dinámica sociedad en crecimiento, caracterizada por la diversidad cultural y la heterogeneidad estructural de sus habitantes, localizados en un tipo de "organización territorial” (Carrión 1987). Es también el 
asiento de las élites, clases altas o familias notables que tradicionalmente han disputado el poder central del Estado, detentado el gobierno local y protagonizado los principales acontecimientos políticos, económicos y culturales de la ciudad, algunas con influencia regional y nacional.

Sus intereses, negocios y visiones condicionaron los vínculos heterónomos de la ciudad con el Estado-nación, de ahí que en la literatura académica lo que se conoce como la "ciudad-región quiteña", o la región "Sierra centro norte" del país, se corresponde con el espacio de influencia económica y política de las clases altas quiteñas. Al respecto, advierto que este trabajo no es un estudio politológico de las élites quiteñas. Sí me interesa develar la hegemonía cultural del poder regional inmerso en la conversión de la capital a distrito metropolitano, proceso en el que los intereses económicos y políticos quiteños tienen un peso importante.

La actual forma espacial dispersa y policéntrica de la ciudad de Quito no es el resultado de una evolución "natural” del territorio, ni su expansión urbana es fruto del espontáneo afán de adelanto de sus habitantes, obedece más bien a los intereses económicos y culturales de los poderes regionales que segregaron, con jerarquías de estirpe colonial, el espacio urbano. Las clases altas ocuparon con privilegios los mejores lugares para la inversión inmobiliaria, residencial, bancaria y comercial, dejando los sitios residuales, los no lugares, para asentamiento de las clases medias bajas y los sectores populares empobrecidos y culturalmente inferiorizados. Generaron un impulso inconsciente, una imagen difuminada de su posición privilegiada, en el que modernidad criolla citadina conlleva una ideología individualista de progreso, ostentando ante los demás los símbolos de la riqueza material y la propiedad privada del suelo.

\section{La configuración de la región quiteña}

La modernidad criolla forma parte de un viejo y, al mismo tiempo, renovado patrón cultural de conformación del poder regional, caracterizado territorialmente como de tipo bicéfalo (Deler 1987), policéntrico (Carrión 1987) o centralismo difuso (Ayala 2011), que se configuró tempranamente en el período colonial, posteriormente readecuado en 
el transcurso de la decimonónica integración nacional en el período republicano, y más tarde remozado durante la renovación estatal y urbana acaecida en el siglo XX, con el tránsito de la ciudad señorial a la modernidad urbana.

Las identidades locales se acentuaron en el inicio de la República, con las disputas regionales por la conformación del Estado-nación (Maiguashca 1994, 360-72). Las confrontaciones eran entre federalistas que buscaban una nueva división político-administrativa en departamentos, y unitaristas que insistían en continuar con la división en provincias sujetas al Ejecutivo; más tarde, fueron disputas entre centralistas que pugnaban por reducir drásticamente la autonomía municipal, y descentralistas que defendían la autonomía municipal proponiendo un sistema administrativo descentralizado (Ayala 2011, 30-47).

En la historia nacional ha sido visible la configuración de tres regiones ${ }^{1}$ políticas con delimitaciones territoriales, económicas y culturales: la Costa, con el puerto de Guayaquil como el polo dominante; la Sierra centro norte con núcleo en Quito e integrada por varios valles interandinos, cada uno con su respectiva urbe referencial, y la Sierra sur articulada en torno a las ciudades andinas de Cuenca y Loja.

En un estudio pionero, Deler (1987) arguyó que en la configuración del espacio nacional ecuatoriano fue decisivo el peso que la colonización española otorgó al sistema urbano, en tanto dispositivo de dominio de los territorios conquistados, del que surgió lo que denominó el "subespacio urbano central", formado por el entrelazamiento de las relaciones complementarias y concurrentes de las ciudades de Quito y Guayaquil que se repartieron, y sobre todo se disputaron, las funciones metropolitanas de "contacto entre las fuerzas externas y los poderes de organización territorial internos” (270). El bicefalismo urbano pasó a ser el área nuclear del espacio ecuatoriano, en torno al cual se desarrollaron los centros urbanos intermedios, los centros urbanos locales y un

1 Sobre el proceso histórico de conformación de las regiones en Ecuador pueden verse los textos de Jean Paul Deler (1987, 239-96), Safford y Jacobsen (2003, 5561), Irurozqui y Peralta (2003, 103-17), y los distintos estudios recopilados en el libro editado por Juan Maiguashca (1994). 
denso entramado de diversos "subespacios periféricos activos y pasivos", marcados por los flujos y las discontinuidades espaciales, económicas y políticas (269-71).

La denominada "región Sierra centro norte" se configuró originariamente en el siglo XVI, en el período colonial tardío, con la delimitación político-administrativa de la llamada "provincia de Quito" que abarcaba los corregimientos de Ibarra, Otavalo, Quito, Latacunga, Ambato, Riobamba, Chimbo y el partido de Alausí (Büschges 2007, 32). La ciudad de Quito cumplía funciones políticas, eclesiásticas y sociales como capital del entonces distrito de la Audiencia, cuando la capa alta de la sociedad local adoptó, con el devenir del tiempo una explícita "identidad de nobleza" (1999), sustentada en un progresivo y combinado control de la producción obrajera, la tenencia de la tierra, el comercio textil indígena —-llamado también el "comercio de Quito" — y los empleos en el cabildo.

Control que favoreció la concentración de bienes y riquezas en contadas familias peninsulares y criollas que se consolidaron, de modo endogámico, por medio de matrimonios y lazos de parentesco direccionados a conservar y acrecentar sus patrimonios a lo largo de varias generaciones, lo que dio lugar a una suerte de alcurnias de prominente reputación social que Ponce Leiva (1998) denominó “élite capitular” de la ciudad de Quito, que estaba compuesta por la "baja hidalguía criolla" y enriquecidos terratenientes o comerciantes con capacidad monetaria que les permitió trepar en la escala social, y que ha sido caracterizada como una "aristocracia de facto aunque no de jure" (422-3).

En Quito el control familiar de los factores de producción se basaba en la importancia que la sociedad local concedía a los puestos administrativos, eclesiales y militares, en la reputación de los llamados "puestos de honor" más que en sus ingresos, que conferían prestigio, estatus social o adscripción a linajes nobiliarios (Büschges 1999, 228).

Durante la Colonia la idea de nobleza organizaba las relaciones sociales de la sociedad quiteña y marcaba sus jerarquías y diferencias, encauzaba de modo flexible la pertenencia a las familias de "linaje encumbrado" para vigilar la integración de nuevos miembros, y devino 
también en condición para el ejercicio de las más altas funciones públicas, con la consecuente influencia en los asuntos legales, administrativos, festivos y simbólicos (229). Los nexos entre control económico, empleo público y nobleza engendraron un jerárquico andamiaje coercitivo que consolidó el control de la élite capitular.

Büschges caracterizó a la capa alta quiteña como una sociedad típica del "Antiguo Régimen", porque al final de la etapa colonial todavía consideraba al origen del prestigio como el factor decisivo en la estructuración de las relaciones sociales (230). La preservación de la economía, la participación en el poder y la mentalidad aristocrática se entrelazaban en las dinámicas diferenciadoras de la sociedad quiteña como el principal elemento integrador de las relaciones sociales, en las que lo aristocrático y los empleos públicos no eran reflejos mecánicos de lo económico sino constitutivos, en sí mismos, de las relaciones sociales (231). Para la colonial élite quiteña las condiciones de la economía, el poder y el abolengo estaban imbricadas en una misma práctica social, al interior de la cual se establecían los límites empresariales y las fortunas económicas, y constituían el principal dispositivo de cohesión social.

La región Sierra centro norte no era solo la continuidad geográfica de sucesivos valles interandinos y diversos pisos ecológicos colaterales, sino también la agregación de procesos económicos y sociales de amplia irradiación territorial, cuyos bordes no son fáciles de delimitar dada la variable influencia económico-política que se acrecentaba o disminuía conforme las distintas coyunturas comerciales, pero que se reproducía de modo relativamente autónomo, exhibiendo una unidad política que le confirió identidad cultural y una memoria territorial que le diferencia de otras regiones, sostiene Yves Saint-Geours (1994, 145). El espacio que se denominó como la región quiteña es, sobre todo, una configuración histórica, política y cultural, más que una delimitación territorial.

Entrado el siglo XIX el autor identificó cuatro tendencias históricas que confluyeron en el proceso regional. Una misma esfera económica de circulación que conectaba hacendados, campesinos libres, pequeños propietarios, artesanos, conciertos y comerciantes. Una misma clase dominante de terratenientes aristocráticos herederos de la antigua nobleza 
capitular que veía a la sociedad como un orden jerárquico natural, en cuya cúspide se autorreconocían y que hicieron de la región su base de poder nacional. Una zona proclive al integrismo religioso con una práctica católica muy enraizada; y un conjunto político-administrativo que acopla a las provincias del Carchi, Imbabura, Cotopaxi, Tungurahua y Chimborazo en una red urbana sometida por las dinámicas que desata la ciudad de Quito (145-9). Durante el período decimonónico estas tendencias regionales sufrieron altibajos y experimentaron modificaciones sustantivas.

Dicho de modo sintético, en la primera época republicana, la región vivió cambios relacionados con la crisis obrajera, la expansión de las actividades agropecuarias y comerciales que empezaron a visualizar al mercado interno como el polo de atracción y crecimiento económico, frente a las resistencias de los campesinos-artesanos impactados por los efectos recesivos del comercio importador textil. Hasta antes del período de la denominada "República Práctica" en el que la utopía de la "República” pasó a ser la movilizadora de las fuerzas productivas, la región quiteña se encontraba relativamente encerrada en sí misma, "era el escenario del conflicto entre dos sistemas: la hacienda y el campesino-artesano” (146).

Posteriormente, en el lapso que Yves Saint-Geours denominó como de "crecimiento discreto (1875-1925)", la región quiteña experimentó un incremento demográfico sostenido y regular, pues la población de la Sierra centro norte literalmente se triplicó en 65 años, la población de la provincia de Pichincha creció en dos veces y medio, y Quito quintuplicó su población que para el año 1825 era de 24000 habitantes, mientras en el año 1933 llegó a 121400 habitantes, no obstante que el peso demográfico de la región Sierra norte era menor, en comparación con la evolución poblacional de las otras regiones del país (146-66). La región, con Quito a la cabeza, se urbanizaba. Crecían las principales ciudades y se diversificaban sus funciones, se mejoraron las vías de comunicación, se activó la movilidad de mano de obra y se transformaron las actividades agrícolas. Entre los años 1888 y 1921 la superficie de la ciudad de Quito había alcanzado las 670,5 hectáreas, lo que representaba un crecimiento urbano del 111,3\%, suscitado en un lapso de 33 años (Instituto de la Ciudad 2013, 13). 
Como señaló Saint-Geours (1994, 171), con el desarrollo capitalista y el surgimiento del mercado interno, nació desde adentro de la hacienda tradicional, en la Sierra centro norte, una nueva tendencia económica y social ligada al mercado de tierras y a la revalorización de los bienes raíces, intensificada con la inversión pública del Gobierno central, que encarecían significativamente las propiedades y haciendas localizadas en las cercanías o en los entornos de las vías de comunicación, carreteras y vía férrea, en detrimento de las haciendas distantes.

Era el inicio de una tendencia de transformación de las grandes propiedades rurales en suelo urbano, que instituía el mercado de tierras y la conversión de los poderosos hacendados quiteños en empresarios inmobiliarios, lo que marcó una de las mayores improntas del crecimiento urbano regional, que más tarde, en el siglo XX, será institucionalizada como "natural" con los planes reguladores del uso y ocupación del suelo, y especialmente con la normativa metropolitana.

Fue un período generalizado de progreso que en la Sierra centro norte estuvo liderado por las antiguas familias hacendarias, que se propusieron reconstituir un espacio económico propio con alcances comerciales hacia el sur de Colombia, provocando leves cambios en las relaciones de producción al introducir innovaciones tecnológicas en la agricultura y ganadería, empujar las actividades manufactureras y promover el resurgimiento de la industria textil (180), aunque todas eran actividades económicas relacionadas con el sistema de hacienda.

Así, las primeras industrias quiteñas fueron una extensión de las actividades productivas agrarias que supieron funcionalizar sus recursos naturales, humanos y productivos, pues los propietarios de las haciendas empezaron a ampliar sus negocios invirtiendo las ganancias, y en algunos casos también capitales extranjeros en el comercio, la industria y posteriormente en las finanzas con la fundación de los primeros bancos quiteños (184). Con las primeras industrias, la ciudad dejaba de ser una urbe predominante de artesanos.

Según Saint-Geours, a comienzos del siglo XX, en la Sierra centro norte, se estaba reconfigurando la élite regional de modo relativamente autónomo respecto de la oligarquía agroexportadora costeña, ya que 
tenía intereses económicos diversos y en buena medida vinculados al mercado interno y con alcance nacional. Era, dice el autor, un proceso direccionado por las tradicionales familias hacendarias quiteñas, en las que persistía el estilo endogámico de control basado en las relaciones interpersonales, parentales y clientelares, en medio de una sociedad local profundamente jerarquizada y estamental que se encontraba inmovilizada por una cultura hegemónica de ribestes religiosos y conservadores, lo que lo llevó a concluir que en esos años la región quiteña fue "el punto de confluencia de la modernidad y una tradición reformulada” (185).

En medio del auge de los guayaquileños "señores del cacao", los terratenientes de la Sierra centro norte también empezaron a organizarse en asociaciones económicas con el propósito de lograr "recursos públicos y privados", así como conseguir el apoyo gubernamental necesario para actualizar la producción y acceder a los mercados internacionales, fundando las primeras Cámaras Regionales de Agricultura, las que debido a su origen localista fracasaron como asociaciones gremiales nacionales, quedando en adelante encapsuladas como agrupaciones regionales o provinciales.

Lo propio ocurrió con las iniciales asociaciones industriales quiteñas fundadas a finales de los años 30 (North 1991, 107-8), evidenciándose, en palabras de Maiguashca y North, la incapacidad elitista para conseguir la unidad nacional, "ni siquiera por sectores de actividad económica” (108), ya que sus organizaciones asentadas en el centro urbano expresaban una "segmentación organizacional regional", y revelaban la persistencia de condiciones conflictivas propias del poder regional desarrollado y legado del siglo anterior.

Más tarde, entrados los años 50 del siglo XX, al calor del nuevo ciclo agroexportador bananero que activó el mercado interno demandante de alimentos y servicios en los centros urbanos, se reconvertía la producción agraria quiteña con la expansión agrícola y ganadera que modernizaba las grandes propiedades rurales, al tiempo que se incrementaba la extensión de tierra dedicada a pastoreo, cultivos mecanizados y la colonización de zonas subtropicales consideradas baldías con fines de expandir la frontera agrícola e implementar la reforma agraria. 
El patrón del poder regional que mantenía un cerrado sistema sociopolítico, mediante una red de las más importantes familias quiteñas que interconectaba la propiedad de las grandes haciendas con la industria textil y la banca privada, también empezó a modificarse.

Aunque el poder quiteño todavía estaba compuesto por antiguas familias propietarias, “entrelazadas entre sí y que poseían múltiples haciendas en toda la región, desde el Carchi hasta Chimborazo" (126), comenzó a diversificar sus intereses y a cambiar su composición social. De ser originariamente grupos familiares endogámicos, pasaron, paulatinamente, a renovarse con el aparecimiento de un nuevo estamento comercial e industrial emergente que cumplía un significativo rol dinamizador de los emprendimientos capitalinos, eran las familias de inmigrantes colombianos, alemanes, italianos, estadounidenses, españoles, libaneses, chilenos, ingleses y franceses (Moscoso 2012). Los inmigrantes extranjeros, desde fines del siglo XIX y a lo largo de la primera mitad del siglo XX, incursionaron en pioneras actividades agropecuarias, comerciales, industriales y de servicios en la ciudad de Quito.

Los inmigrantes crearon 332 industrias en el país. En Quito fundaron importantes empresas financieras y de seguros, compañías industriales y comerciales como Kywi, Ideal Alambrec, Plastigama, Omega, Life, La Química, librerías como La Científica, Su Librería, Papelería Paco, Almacenes El Globo, Embutidos Juris, Federer, fábricas de encauchados, brochas y pinturas, chocolates, panadería, y en general abrieron tiendas de productos europeos con buena acogida en Quito, además de instituciones como la Cruz Roja Ecuatoriana, y los colegios Alemán y Einstein (159). La mayoría de las empresas de los inmigrantes extranjeros estaban asentadas preferentemente en la zona comercial del entonces centro de la ciudad.

El estudio de David Hanson, citado por Maiguashca y North (1991, 127), registró a mediados de los años 60 el surgimiento de una división en las viejas familias terratenientes quiteñas: los tradicionalistas y los progresistas ante la presencia de los inmigrantes extranjeros, lo que incidiría en la conformación de las nuevas redes empresariales quiteñas, no obstante que lo sustantivo de la economía agraria, textil y bancaria seguía vinculada a las más importantes familias hacendarias locales. 
Mientras los terratenientes considerados como "progresistas" hacían negocios con los inmigrantes extranjeros y establecían alianzas con los empresarios urbanos por medio de lazos matrimoniales, dado que "perseguían fines económicos comunes"; los terratenientes tradicionalistas, en cambio, los veían con desconfianza por su condición de "incultos nuevos ricos" (127), y preferían mantenerse a distancia.

Lo que había sido una débil presencia económica de los terratenientes locales en la incipiente dinámica empresarial de la capital empezó a cambiar mediante las alianzas con las familias de inmigrantes. Los matrimonios entre inmigrantes extranjeros pudientes y familias hacendarias quiteñas ensanchaban a los grupos comerciales-industriales quiteños, con la incorporación de nuevos miembros y relaciones, al tiempo que diversificaban sus inversiones en la ciudad.

\section{Empresarios modernos y concentración de capitales}

El avance de las empresas y grupos económicos quiteños fue registrado por Guillermo Navarro (1976), quien estudió lo que denominó la concentración de capitales, en el período 1960-1973, de "los grupos económicos más poderosos de la burguesía”. Analizó el 51,5 \% del total de compañías anónimas activas, y el 15 \% de todas las empresas que operaban en el país. Constató que lo fundamental del empresariado quiteño seguían siendo los negocios familiares, agrandados gracias a la inversión de capitales extranjeros y a los negocios con los inmigrantes, que las empresas se integraban vertical y/o horizontalmente para acrecentar su influencia económica con la "conglomeración funcional y geográfica”, lo que aseguraba las inversiones y extendía su alcance fuera de la provincia (18-9). Esta modalidad de crecimiento empresarial permitió que los capitales nacionales y extranjeros operaran también por medio de trusts familiares, señaló el autor.

Navarro definió a los "grupos económicos familiares" como la agregación de empresas anónimas, bancos y seguros en los que la participación en su accionariado es únicamente de los padres, hijos y/o parientes cercanos (57). Clasificó los "núcleos familiares" según el número de empresas que controlaban y el ámbito geográfico de acción, con lo 
que estableció dos tipos de grupos familiares: los que controlaban una sola empresa con alcance provincial, que denominó "grupo provincial", y los que controlaban numerosas empresas localizadas en varias provincias y ramas de actividad con alcance nacional, que denominó "grupo nacional" (57).

Encontró que el número de empresas controladas por los grupos provinciales era mayor que los grupos nacionales, pero su participación en el capital y los activos era menor y estaban dispersas; mientras que las empresas controladas por los grupos nacionales tendían a una alta concentración y participación familiar, observándose casos, dice el autor, de una misma familia que controlaba trece empresas y participaba hasta en dieciocho (59).

El estudio ratificó el patrón regional de la organización económica del país, así como la diferenciación entre las empresas quiteñas orientadas preferentemente al mercado interno, y las empresas guayaquileñas y azuayas alineadas predominantemente a la exportación. En la muestra estudiada por Navarro se colige, además, que los empresarios quiteños controlaban o conformaban por igual los grupos económicos provinciales y nacionales.

El auge de las exportaciones petroleras en los años 70 dio nuevos impulsos a la diversificación y expansión de las actividades económicas y empresariales de la ciudad, afianzando la propensión a la concentración económica en pocos grupos familiares como lo ratificó el estudio de José Moncada (1983), que en el año 1980 señaló que la "burguesía monopolista ecuatoriana" estaba compuesta por un centenar de familias, que controlan no más de veinte grandes grupos económicos que operan en múltiples ramas y con capitales interrelacionados, íntimamente vinculados a los capitales extranjeros bajo modalidades de socios, clientes, amigos, representantes o distribuidores de productos (25).

Analizó las treinta mayores empresas del país — doce de las cuales eran quiteñas - clasificadas según sus montos de ventas, y encontró que más de una tercera parte se dedicaba a la producción de alimentos, bebidas y tabacos; otro tercio al comercio al por mayor, y las restantes a diversas manufacturas y servicios; confirmando el carácter predominan- 
temente primario de la industrialización ecuatoriana y el enorme peso de la actividad comercial (50), tanto en las empresas costeñas agroexportadoras como en las empresas quiteñas para el mercado interno.

En los años siguientes continuó el crecimiento de las mayores empresas quiteñas, las que tendían a aglomerarse en los sectores secundario y terciario de la economía urbana, con predominio en los subsectores de la construcción, alimentos, comercio y servicios. Las actividades económicas se ampliaron hacia ámbitos más complejos y sofisticados, derivados de los nuevos requerimientos de insumos y tecnología de una economía ligada a la expansión urbana y el mercado interno.

Se edificaron y montaron "empresas fabriles más complejas" que las existentes en años anteriores, como la producción de tableros eléctricos, alambre galvanizado, perfiles de aluminio, fibras de nailon y poliéster, herramientas electromecánicas, aparatos de corte y seccionamiento, papeles especiales, tubería a presión de cemento y asbesto, refinación de petróleo, medicamentos, sustancias químicas, harina y aceite de pescado, y el montaje automotriz (72). Sus instalaciones, plantas procesadoras, ensambladoras, embalaje, bodegas y almacenes se asentaban indistintamente en las zonas comerciales y fabriles de los costados de la ciudad, demandando infraestructura básica, servicios y equipamiento, convirtiéndose en vectores de la expansión urbana.

La industria creció y duplicó el "número de empresas que hasta principios de 1960 se habían instalado en la ciudad”, en condiciones en las que no se habían tomado medidas preventivas para manejar ese aumento, el municipio no disponía de una política para los asentamientos industriales, se "limitaba a legalizar los asentamientos ya existentes". No obstante, en un período aproximado de veinte años, entre 1957 y 1975 , en Quito se establecieron 320 nuevas empresas industriales que representaban el $42 \%$ de las empresas del país (IMQ 1980, 216).

De acuerdo con Moncada (1996, 72), en el período 1970-80 no solo se emplazaron nuevas empresas en ramas más complejas de la actividad económica, sino que también numerosas empresas ya instaladas ampliaron sus equipos, aumentaron la producción o renovaron sus líneas de producción, especialmente las empresas textiles, de alimentos, 
tabaco y editoriales. Del mismo modo, las políticas de redistribución económica del Gobierno nacional crearon estímulos para el sector de la construcción, particularmente por las políticas de vivienda y la disponibilidad de fondos públicos para construir carreteras, plantas hidroeléctricas, puertos y telecomunicaciones.

La diversificación productiva también abarcó la instalación y expansión de las plantaciones de flores y hortalizas, asentadas en las haciendas circundantes a la capital del país, iniciándose el auge exportador de los productos agroindustriales no tradicionales serranos, lo que creó un espejismo de que se estaba modificando el patrón regional de poder, sobre lo que Gonzalo Ortiz Crespo $(2000,32)$ afirmó que el diseño centenario de una Costa exportadora y una Sierra abastecedora al mercado interno cambió radicalmente, pues "todos querían exportar".

Sin embargo, según el mismo Ortiz Crespo, el análisis de la composición del comercio internacional en el período dejaba ver que las mayores empresas exportadoras eran las que vendían productos del mar y banano, mientras que las mayores importadoras eran las que traían los insumos para la agroexportación y para la fabricación de alimentos de consumo interno (38), evidenciándose que la imagen de ir más allá del patrón regional solo había sido una fugaz ilusión.

Por su lado, el estudio de María Granja (1986) ratificó que el sector financiero y bancario también formaba parte de la concentración económica en grupos familiares. Aunque desde sus inicios la banca privada nació vinculada a las familias prominentes, fue en los años 70 del siglo XX que inició un proceso formal de fusión de los capitales financieros con los capitales industriales y comerciales, gracias al apoyo estatal (1986), lo que facilitaba el control crediticio y la vinculación al capital extranjero.

La autora recuerda que en el país los bancos privados no podían "penetrar" en la estructura de propiedad accionaria de las empresas productivas y comerciales beneficiadas con los créditos bancarios, pues las relaciones entre la banca privada y las empresas estaban limitadas a los vínculos entre accionistas, y que fue a fines de los años 80, con el cambio de la Ley de Concordato, que se facilitó la fusión del capital 
bancario con el capital productivo, y la consecuente conversión de los acreedores en accionistas (87), consolidándose la integración familiar de los grupos económicos.

Granja reseña las múltiples formas de apoyo estatal a la banca privada: las políticas fiscales de precios y salarios, las políticas económicas que mantienen subsidios productivos, las políticas monetarias y crediticias que fijan la circulación monetaria, la deuda pública, las tasas de interés, el mercado abierto, el encaje económico legal, las tasas de redescuento, los topes de cartera, y las políticas de crédito selectivo en la concesión de recursos financieros que controlan la liquidez e impulsan la acumulación y concentración del capital (1986). Además, señaló que, en el período 1980-84, la mayoría de representantes de los bancos privados en la Junta Monetaria eran quiteños.

El hecho es que, para el año 1984 y en medio de la recesión económica que atravesaba el país, 21 de los 32 bancos que existían en el país, esto es el 65,6 \%, estaban integrados a grupos financieros familiares, entre ellos los cuatro bancos más grandes caracterizados como monopólicos, dos de los cuales eran quiteños, controlaban la mayor parte del capital bancario nacional invertido en las ramas económicas más importantes (con mayores montos) como alimentos, comercio, textiles y financieras (85).

La autora considera como bancos monopólicos aquellos que tenían el mayor número de oficinas o sucursales en el país, el mayor capital pagado, fondos de reservas y las mayores utilidades, y que coincidentemente eran los mismos que recibían los mayores créditos del Banco Central del Ecuador (BCE), con lo que los dos bancos quiteños estaban también entre los cuatro bancos que tenían el mayor control del crédito nacional, ratificando la existencia de monopolios en el sector bancario privado y que el Estado, mediante el BCE, contribuía a ellos (139).

El salto histórico de una economía agraria y comercial a una economía urbana y de servicios, brevemente reseñado, revela el dominio del conglomerado de intereses de los grupos económicos quiteños asentados en la ciudad, de la que hicieron el área nuclear de su influencia regional. La reciente modernización de la urbe está imbricada con los 
flujos de capitales inmobiliarios, financieros, comerciales y de servicios, y con el simbolismo de los poderes regionales. Lo que para las élites quiteñas fue inicialmente un empleo honorífico en el cabildo, se convirtió en el control del poder local para asegurar entornos providenciales para sus negocios, entre estos dotar de las condiciones de habitabilidad a las crecientes clases medias y populares demandantes de vivienda, servicios, bienes y alimentos.

Las clases altas y élites quiteñas supieron acoplar el manejo del territorio y el gobierno local en un orden jerárquico de ribetes coloniales que atravesaba al espacio y la sociedad, prolongado, además, en el sentido cultural de las políticas, acciones y presiones públicas que, como en todas las urbes modernas, modulan los vínculos entre gobernantes y gobernados (Reinhard 1997). En el proceso se fraguó la articulación heterónoma de la ciudad-región quiteña con el Estado-nación ecuatoriano, por la que la economía regional con asiento en la ciudad formó parte de la concentración de capitales del país. Lo que ocurre económica y políticamente en la capital repercute en la región y afecta al país; en sentido inverso, la propulsión de la centralidad estatal afecta la cotidianidad de la ciudad, con lo que la mutualidad de intereses hizo porosa la frontera entre la nación y la región, y se solaparon los ámbitos públicos y privados en su gestión.

Si bien son numerosos los elementos enlazados en el proceso contemporáneo de crecimiento regional, señalo tres aspectos relevantes por su incidencia en la conformación del DMQ. El primero es la conversión espacial de la vieja ciudad-región agraria, que transformó la pequeña urbe colonial enlazada a un territorio de haciendas y poblados y emplazada en un escenario de fuerzas históricas centrífugas (Maiguashca 1993), derivadas del rol económico de las haciendas de la Sierra centro norte respecto de Quito, en una ciudad-región con una expandida “área metropolitana”, en la que se vertebran un conjunto de ciudades intermedias y varias conurbanizaciones circundantes, emplazada, en cambio, en un escenario de fuerzas históricas centrípetas resultantes de las crecientes demandas de recursos naturales, económicos y sociales con la nueva inserción del país en el comercio internacional (200). La antigua 
ciudad de "tipo radial concéntrica" se convirtió, progresivamente, en una extendida ciudad longitudinal policéntrica (Carrión 1992, 322-3).

En el pasado reciente, la ciudad-región se correspondía con el área de influencia de las haciendas de las familias nobiliarias quiteñas, en una dinámica económica administrativa que iba desde la ciudad al territorio; la urbe era el lugar de residencia de las élites agrarias serranas, y la economía estaba en las haciendas. Contemporáneamente, la ciudad-región devino en la geografía de especialización productiva y de servicios de Quito respecto del mercado nacional e internacional, en una dinámica económica administrativa inversa que va del territorio a la ciudad; la economía pasó tanto a la ciudad como a la región.

La conversión urbana, especialmente a partir de la segunda mitad del siglo XX, provocó el ensanchamiento del área metropolitana de Quito como resultado de la aglomeración del complejo productivo, financiero y de servicios propia del crecimiento económico regional, no siempre con un arreglo planificado, que sigue algún orden urbano para preservar lo rural, sino con implantaciones industriales, residenciales y comerciales desordenadas, conforme los intereses del naciente sector inmobiliario capitalino.

El Plan Quito de 1980 advirtió la tendencia desorganizada de los asentamientos industriales y manufactureros, en ausencia de una "infraestructura prevista para el expansión industrial", las plantas y fábricas se edificaban en sitios que no disponían de las condiciones básicas de energía eléctrica, agua, alcantarillado, incluso sin vías de acceso, creando polos precarios de expansión urbana. Se asentaban "bajo su propia lógica de implantación y entremezclada con el resto de actividades", atomizadas en forma desordenada, sujetas "al libre juego del mercado de tierras" (IMQ 1980, 216).

La ciudad-región y el gobierno municipal quiteño estaban presionados por las exigencias de localización productiva, comercial y de servicios, pues las distancias a los centros productivos y de comercio, la calidad de las vías, las condiciones de infraestructura y equipamiento, la variedad climática y la densidad propia de la ciudad influirán en las dinámicas de la economía regional. La conversión de la ciudad-región 
quiteña estaba entrelazada con el desarrollo nacional desigual, pues el crecimiento urbano era parte de la especialización geográfica regional y de la tendencia a la concentración de capitales.

El segundo aspecto es que, con la conversión de la ciudad-región quiteña, se diversificaron y consolidaron los negocios privados, robusteciéndose los sectores inmobiliario, con tendencia monopólica; manufacturero, que se incrementó regionalmente sobre el resto del país; financiero, que creció en número conservando la concentración crediticia; comercial, que se expandió en las ciudades intermedias de la región, y estatal, que incrementó notablemente las sedes del Gobierno central en la capital.

Con la conversión, se estimuló el crecimiento urbano de Quito, especialmente durante los años 70 por el auge petrolero que acrecentó la economía regional. La ciudad había entrado en un proceso de renovación y expansión urbana que ensamblaba la integración territorial zonal y conurbana, con la dispersión de actividades urbanas funcionales y la concentración-fraccionamiento de la propiedad del suelo, lo que en conjunto redujo la "fricción que impone el suelo urbano a la acumulación de capital” (Carrión 1987, 86). El proceso fue posible gracias a lo que Carrión (86) denominó una "política urbana concertada", por la que el capital asume los mayores beneficios de la transición, las élites locales se apropian de la renta de la tierra generada socialmente, y el Estado, por medio del municipio, asume los costos de la conversión que no son rentables.

La consolidación de la ciudad compacta y la expansión urbana hacia las zonas suburbanas circundantes formaron un área metropolitana cuya dinámica no obedecía solo a la evolución urbanística o al crecimiento poblacional como consecuencia del avance de la ciudad. La modernidad urbana se relacionaba también, directamente, con la conversión de la ciudad-región y los impulsos del poder regional quiteño para insertarse en el sistema económico internacional.

El tercer aspecto es que el actor protagónico que cohesionó culturalmente la transición de la ciudad-región fueron las élites económicas quiteñas. El proceso histórico muestra que los poderes regionales han 
mantenido continuidad en la estructura social de la ciudad, aunque no es clara la formación de una burguesía quiteña que se muestre distinta y escindida de las tradicionales familias terratenientes, los nuevos empresarios urbanos no se dejaron ver como un sector económicamente diferenciado con intereses propios, incluso opuestos, sino que se mantenían, en los años 70 y 80, entroncados a los viejos grupos agrarios y comerciales de la región Sierra centro norte, entre los que emergió una tendencia a la acumulación urbana de capital con base en la diversificación de capitales inmobiliarios, financieros y comerciales.

Era una "estrategia terrateniente" rentista de valorizar el suelo de toda la ciudad, transfiriendo los costos económicos a los sectores populares con la apropiación de la renta del suelo, en condiciones en que la propiedad del suelo urbano era extensión de la propiedad rural y fuente de "valorización de la renta absoluta", lo que dio origen al capital inmobiliario rentista, señaló Carrión (1992, 325).

Las familias encumbradas o las élites económicas quiteñas supieron enlazar estratégicamente sus intereses, eslabonando inversiones empresariales desde los ámbitos agrarios y comerciales hacia los sectores industrial, financiero e inmobiliario, en una intensa interacción gremial, corporativa e individual que les hace ver como si fuesen varios estamentos o grupos empresariales que emprenden sus negocios en una situación de relativa competencia entre sí, aunque en realidad forman un bloque hegemónico regional. Condición que llevó a Maiguashca (1993, 221-2) a afirmar que, a diferencia de los otros poderes regionales, como el guayaquileño que está conformado por una élite de pocas familias patricias o el cuencano integrado por una sola casta nobiliaria local, en el caso del poder quiteño no hay una élite sino varias élites regionales.

A partir de 1946 en que la Asamblea Constituyente restituyó la dignidad de alcalde en los municipios capitales de provincia, instituida en la Colonia y suprimida con la formación de la República, hasta el año 2014 la ciudad de Quito ha tenido veintitrés alcaldes. De estos, los primeros diez estuvieron emparentados con las familias nobiliarias y hacendarias, a los que entre los años 60 y 90 les sucedieron siete alcaldes vinculados a los círculos empresariales, y desde los años 90 en adelante 
los seis alcaldes han sido políticos profesionales. La secuencia de aristócratas, empresarios y políticos en el gobierno de la ciudad es indicativa de la estabilidad política municipal capitalina, en buena medida prodigada por su inmediatez con los círculos del poder local.

En el curso de algo más de setenta años la ciudad de Quito tuvo dieciséis alcaldes de elección popular, tres designados por la Junta Militar de 1964, uno electo y ratificado por la dictadura militar de 1972, y cinco por sucesión cuando los alcaldes titulares renunciaron para participar en elecciones presidenciales, como puede verse en la siguiente tabla:

Tabla 1

Alcaldes de Quito electos según filiación política

\begin{tabular}{|c|c|c|}
\hline Partidos políticos & Alcaldes & Períodos \\
\hline $\begin{array}{l}\text { Partido Conservador } \\
\text { Ecuatoriano }\end{array}$ & $\begin{array}{l}\text { Jacinto Jijón y Caamaño } \\
\text { Alfonso Pérez Pallares (sucesión) } \\
\text { Rafael León Larrea } \\
\text { Jorge Vallarino Donoso }\end{array}$ & $\begin{array}{l}1946-1948 \\
1948-1949 \\
1952-1955 \\
1962-1963 \\
\end{array}$ \\
\hline $\begin{array}{l}\text { Designados por la } \\
\text { Junta Militar }\end{array}$ & $\begin{array}{l}\text { Gonzalo Pérez Bustamante } \\
\text { Luis Román Pérez } \\
\text { Luis Pallares Zaldumbide }\end{array}$ & $\begin{array}{l}1963-1965 \\
1965-1966 \\
1966-1967\end{array}$ \\
\hline $\begin{array}{l}\text { Partido Liberal Radical } \\
\text { del Ecuador }\end{array}$ & $\begin{array}{l}\text { José Ricardo Chiriboga } \\
\text { Carlos Andrade Marín } \\
\text { Julio Moreno Espinosa } \\
\text { Álvaro Pérez Intriago } \\
\text { Luis Andrade Nieto (sucesión) }\end{array}$ & $\begin{array}{l}1949-1952 \\
1955-1959 \\
1959-1962 \\
1978-1982 \\
1982-1984\end{array}$ \\
\hline $\begin{array}{l}\text { Frente Nacional } \\
\text { Velasquista }\end{array}$ & Jaime del Castillo Álvarez & $1967-1970$ \\
\hline Partido Social Cristiano & $\begin{array}{l}\text { Sixto Durán Ballén (ratificado } \\
\text { por dictadura militar) } \\
\text { Alberto Donoso (sucesión) }\end{array}$ & $\begin{array}{c}1970-1978 \\
1978\end{array}$ \\
\hline Partido Demócrata & Gustavo Herdoíza & 1984-1988 \\
\hline Democracia Popular & $\begin{array}{l}\text { Rodrigo Paz } \\
\text { Jamil Mahuad (reelecto) } \\
\text { Roque Sevilla (sucesión) }\end{array}$ & $\begin{array}{l}1988-1992 \\
1992-1998 \\
1998-2000\end{array}$ \\
\hline
\end{tabular}




\begin{tabular}{|l|l|c|}
\hline Izquierda Democrática & $\begin{array}{l}\text { Paco Moncayo (reelecto) } \\
\text { Andrés Vallejo (sucesión) }\end{array}$ & $\begin{array}{c}2000-2009 \\
2009\end{array}$ \\
\hline Movimiento Alianza PAIS & Augusto Barrera & $2009-2014$ \\
\hline Coalición SUMA-VIVE & Mauricio Rodas & $2014-2019$ \\
\hline $\begin{array}{l}\text { Movimiento Unión } \\
\text { Ecuatoriana }\end{array}$ & Jorge Yunda & $2019-2023$ \\
\hline
\end{tabular}

Fuente: Gomezjurado Zevallos, Javier. 2015. Quito: Historia del cabildo y la ciudad. Quito: Instituto Metropolitano de Patrimonio. Consejo Nacional Electoral, 2019. Elaboración: autor.

Desde el punto de vista de los partidos políticos que gobernaron la ciudad de Quito, seis alcaldes provinieron de las filas del Partido Liberal Radical del Ecuador, cinco del Partido Conservador Ecuatoriano, uno del Partido Demócrata, uno del Partido Social Cristiano (PSC), uno reelecto en dos períodos de la Democracia Popular (DP), uno igualmente reelecto en dos períodos de la Izquierda Democrática (ID) y uno de Alianza PAIS, uno de la coalición SUMA y VIVE y, el último, del movimiento Unión Ecuatoriana.

Salvo los casos de la ID, de postura centroizquierdista, Alianza PAIS, alineado a la izquierda, y el Movimiento Unión Ecuatoriana, que canalizó la votación de los barrios periféricos de la ciudad, todos los demás alcaldes quiteños han sido auspiciados por partidos de centroderecha y derecha. El Concejo Municipal iba integrando de forma paulatina a representantes de los grupos económicos y sociales en ascenso, surgidos con la conversión regional y la modernidad urbana; con el paso del tiempo, el municipio dejó de ser un ente corporativo controlado por círculos restringidos de las familias nobiliarias, para constituirse en un gobierno local representativo de las plurales fuerzas políticas de la ciudad.

La mayoría de partidos políticos a los que pertenecieron los alcaldes capitalinos fueron alineamientos de fuerzas electorales con alcance nacional, no se trataron de coaliciones transitorias locales, salvo el caso de los dos últimos alcaldes electos que montaron maquinarias electorales ad hoc para las elecciones municipales y con alcance local. La mayoría fue auspiciada por agrupaciones partidarias nacionales creadas y promovidas desde la ciudad de Quito, que, al mismo tiempo, terciaban por la alcaldía 
y también por la Presidencia de la República y el Congreso Nacional, eran los partidos políticos del "antiguo régimen", ahora en franca decadencia.

La capital del país ha sido el asiento de sólidos alineamientos e intereses, primero de las fuerzas políticas liberales y conservadoras; luego, de las variantes socialdemócratas y democratacristianas; lo que ratifica el carácter heterónomo de las relaciones políticas entre los poderes regionales quiteños, las élites gubernamentales de la ciudad y el poder del Estado nacional, que en determinadas coyunturas establecieron continuidades económicas y complementariedades políticas.

En la transformación institucional jugó un papel sustantivo la adopción de dispositivos de planificación que racionalizaban la gestión municipal. La administración de una ciudad que crecía sin control se hacía más compleja, pues los acostumbrados "planes de obras municipales" no eran suficientes. Los alcaldes capitalinos, con una clara vocación modernizadora, adoptaron tempranamente la planificación urbana como apoyo o referencia técnica para la administración de la ciudad, que en adelante se guiaría por enfoques proyectados de uso del suelo y dotación de servicios, aunque en la práctica la mayoría de los planes urbanos fueron desbordados por el crecimiento urbano desordenado (aspectos que se explican en el segundo capítulo).

Los símbolos espaciales de la modernidad capitalista: avenidas, pasos a desnivel, edificios, ciudadelas, urbanizaciones, programas de vivienda social y numerosos barrios periféricos, revelan una expansión de la ciudad más allá de los tradicionales ejidos y el damero colonial, formándose nuevas centralidades hacia el norte, sur y oriente, a manera de focos de irradiación del crecimiento urbanístico, con los consecuentes problemas de servicios, equipamiento, infraestructura y movilidad urbana.

\section{La conversión urbana metropolitana}

Los primeras propuestas para la creación del DMQ se remiten a la alcaldía de Sixto Durán Ballén, quien ganó las elecciones locales en 1970 y con la dictadura militar de 1972 fue ratificado como alcalde de la ciudad hasta el año 1978, cuando renunció para candidatizarse para presidente en las elecciones que inauguraban el retorno a la democracia. 
Durante su alcaldía tuvo la iniciativa de proponer el DMQ, con facultades extraordinarias para la administración directa del tránsito vehicular, al igual que sucedía en las grandes ciudades norteamericanas (La Hora 2012), enfocado como estaba en la construcción de avenidas, pasos a desnivel y los tres túneles del centro suroriental, ante el crecimiento urbanístico experimentado en la década del 60 .

Con sus enunciados se elaboró el documento "Quito y su área metropolitana, Plan director 1973-1992”, que, aunque no fue aprobado oficialmente por el Concejo Municipal, contenía las primeras directrices estratégicas sobre el área metropolitana, las finanzas municipales y el funcionamiento institucional (PUOS 2003, 7). El plan planteó desconcentrar los emplazamientos industriales a nuevas áreas de "alta composición de capital e inversión extranjera”, formar ciudades satélites que proveyeran fuerza de trabajo, un circuito de transporte para conectar las áreas industriales y beneficiar el comercio, y la apertura municipal a la inversión extranjera para autofinanciar proyectos y la deuda externa (Carrión 1992, 342), este último un argumento decisivo en la conversión del municipio en empresa.

Las directrices metropolitanas fueron retomadas en el Plan Quito de 1980 que tampoco tuvo capacidad reglamentaria, por lo que no se emprendieron actividades municipales ni urbanísticas en este sentido. La Constitución de 1979 había reconocido a Quito capital de la República como Distrito Metropolitano, por primera vez se adoptó el término en la legislación ecuatoriana, aunque de modo figurado, pues tuvieron que transcurrir catorce años para su puesta en vigencia.

Mientras tanto, Quito había experimentado el mayor crecimiento urbano en la segunda mitad del siglo XX. Para 1956 la urbe quiteña tenía una extensión de 3311,5 ha, que para entonces representaban un crecimiento urbano del $86 \%$. Tres lustros más tarde, en 1971 el tamaño de la ciudad alcanzó las 5 188,8 ha, había crecido 56,7 \%. Doce años después, en 1983, como consecuencia de la dinamización económica provocada por el auge petrolero, la ciudad se había expandido en más del doble de su tamaño, llegando a las 12468 ha, que equivalían a un crecimiento del 140,3\%. En adelante, la ciudad continuó expandiéndo- 
se a un ritmo menor, pues en 1987 el tamaño de la urbe era de 15 818,8 ha, había crecido el 26,9 \% (Instituto de la Ciudad 2013).

Múltiples factores convergieron en su crecimiento urbano. De acuerdo con los datos censales, la población urbana de Quito en 1950 era de 209932 habitantes, en 1962 aumentó a 354746 habitantes, con un crecimiento promedio anual del 4,4\%, en 1974 eran 599828 habitantes y una tasa de crecimiento del 4,3\%, en 1982 alcanzó la cifra de 866472 habitantes y una tasa de crecimiento del 4,3\%, y para el año 1990 los habitantes de la capital eran 1100847 y la tasa de crecimiento del $3 \%$ (MDMQa 1995, 6). El aumento demográfico ocurría con la conformación de nuevas áreas residenciales y de servicios en la zona nuclear extendida, así como en los costados de la ciudad y en los valles circundantes.

Se había revertido también la dinámica del crecimiento poblacional urbano de la capital pues, si en 1960 el 1,1 \% de la tasa de crecimiento fue atribuido a la migración, y el 3,3\% al crecimiento natural, en 1990 el patrón de crecimiento se invirtió: el crecimiento por migración fue del 2,9 \% y el crecimiento natural del 1,6 \% (5). El ritmo de crecimiento de la población tendió a disminuir desde 1990.

En la ciudad se habían instalado, de modo progresivo, numerosas empresas productivas, comerciales y de servicios que demandaban lugares, infraestructura y equipamientos urbanos. Asimismo, ocurrió un formidable crecimiento viviendístico debido a la promoción inmobiliaria privada, a los primeros planes mutuales de los años 60, influenciados por la Alianza para el Progreso (ALPRO), y en las décadas 70 y 80, con los programas estatales de vivienda masiva dirigidos a las clases medias y populares en el sur y norte de la ciudad. A finales de los 80 , el cantón Quito estaba dividido en 16 parroquias urbanas y 36 parroquias rurales, y contaba con 667 barrios urbanos, 180 de estos periféricos (4).

Las propiedades agrarias de distintos tamaños se convirtieron en tierras urbanizables, extensos territorios rurales se fragmentaron en múltiples lotizaciones, urbanizaciones, cooperativas y barrios formales e informales. Con la conformación de los barrios periféricos en el área metropolitana de la ciudad, entre 1981 y 1991 se fraccionaron tres mil hectáreas en cerca de veinticinco mil lotes en los alrededores de las cabe- 
ceras parroquiales, de manera dispersa y discontinua, impactando en los entornos productivos agrarios y ambientales, al tiempo que precarizaba los asentamientos humanos (Carrión 1994, 204). Ocurría una inusitada expansión urbana que sometía a la ruralidad.

\section{El simbolismo elitista de la decisión municipal}

El espacio urbano se amplió con la intersección de diversas dinámicas económicas, demográficas, viviendísticas, de servicios, movilidad y seguridad, lo que complejizaba la gestión municipal de la ciudad. Con el trazo de nuevas avenidas y autopistas que conectan a los valles circundantes, el emplazamiento longitudinal extendido de la urbe en el centro de la depresión geográfica se desbordó hacia los valles orientales y a los extremos norte y sur, especialmente hacia las parroquias rurales de Pomasqui, Calderón, Tumbaco, Conocoto y Amaguaña, donde se formaron nuevas centralidades urbanas. Quito se había convertido en una urbe policéntrica.

Igualmente, la gestión de la ciudad estaba enredada con distintas intervenciones de sujetos privados que implementaban negocios y emprendimientos urbanos, y de instituciones públicas que ejercían funciones dentro de la ciudad sin ninguna coordinación, provocando un solapamiento de competencias entre el municipio, el gobierno provincial y las distintas entidades del Gobierno central, cuestión que por la condición de capital tendía a enredarse aún más. Por ejemplo, en el manejo del tránsito en la ciudad intervenían nueve instituciones estatales, en palabras del entonces alcalde Rodrigo Paz: “aquí el tránsito de la ciudad es compartido, por eso es tan malo, los túneles son compartidos, la estación del terminal es compartida, hay nueve instituciones que determinan lo que hay que hacer en el tránsito de cada ciudad del país" (Acta-O 1990, 60).

Sobre todo, no estaban claros los ámbitos urbano y rural del área metropolitana que se había formado con la expansión de la ciudad, la que se encontraba enredada en regulaciones públicas superpuestas que bloqueaban la consolidación urbana. En la práctica, la acción municipal había llegado a ser una cuasi gestión metropolitana, una suerte de descentralización fáctica, de hecho y no de derecho, que habían asumido 
las autoridades de la ciudad. Se hacía urgente esclarecer los límites territoriales del ámbito urbano de la ciudad, como lo evidenció el asesor del alcalde Alberto Wray en la primera reunión del Cabildo Municipal en la que se planteó la propuesta del distrito metropolitano, cuando en la parte pertinente de sus fundamentos argumentó que:

Quito tiene una zona de influencia que en primer lugar excede a los límites urbanos de la ciudad; en segundo lugar, excede a los límites políticos del cantón como tal y los problemas que plantea la planificación dentro de esta zona de influencia se vuelven prácticamente insuperables por la intervención de otros órganos del Estado, el caso del IERAC es tal vez más frecuente, en orden a definir aspectos tan importantes como el uso del suelo con criterios distintos a los que utilizaría la planificación del suelo tomada con criterio urbano. (Acta-E 1990, 15)

La ciudad se había convertido en una urbe dinámica y compleja, que establecía relaciones de coordinación con los otros niveles de gobierno subnacional, pero la legislación local se mantenía congelada en la Ley de Régimen Municipal (LRM) del año 1971, cuyos contenidos reproducían viejos cánones municipalistas de comienzos del siglo, los que se mostraban insuficientes y atrasados ante la compleja realidad que enfrentaba la capital del país. Wray señaló que la ley no era eficaz ante los problemas de la ciudad de Quito y de su cantón, poco funcional dado que había "una diferencia cualitativa de situaciones entre la capital Quito y sus otros cantones" (13). La ley trataba de modo uniforme a los municipios, sin consideración a sus diferencias, tamaños y menos aún a las características urbanas de los municipios en las grandes ciudades de Quito y Guayaquil. Como lo señaló en su momento Fernando Carrión:

El Municipio en este contexto, además de ser un aparato de gobierno que poco se ha actualizado desde su nacimiento, ha sufrido la invasión de otras competencias provenientes de otros tantos órganos estatales centrales o provinciales, lo que en su conjunto ha dado lugar a una red institucional que atrofia el desarrollo de la ciudad. $(1994,186)$

A finales de los años 80 se hizo patente que no se podía postergar la renovación del marco institucional municipal para la gestión de la ciudad capital, por lo que transcurridos dos años de la alcaldía de 
Rodrigo Paz, exitoso empresario a la cabeza de un poderoso grupo económico quiteño con inversiones en el sector financiero, inmobiliario y comercial, además de dirigente deportivo, convocó al atardecer del lunes 4 de junio de 1990, a la primera Sesión Extraordinaria del Concejo Municipal en la que se trataría, como único punto del orden del día, el proyecto del DMQ. El tema fue una de las consignas centrales en su campaña electoral a la alcaldía, en la que había retomado la iniciativa del exalcalde Sixto Durán y que ahora proponía para su consideración y mejora, no para la decisión del Concejo Municipal.

El concejo estaba integrado por quince ediles, representantes de tres bloques paritarios de partidos políticos de centroderecha: DP, ID y PSC, y dos representantes de la izquierda: el Frente Amplio de Izquierda (FADI) y el Partido Socialista Ecuatoriano (PSE) (Acta-E 1990). Operando en una alianza de facto entre los tres partidos de centroderecha y el alcalde, el concejo respaldó las iniciativas emprendidas por este, en una gestión concertada que se evidenció, claramente, al recibir el apoyo total para el proyecto de distrito metropolitano.

El alcalde no estaba colocando un tema para que se sometiera a votación de los concejales, menos aún para que fuera cuestionado, no era ese el sentido de la propuesta. Se trataba de una iniciativa de la primera autoridad, suficientemente asesorada y elaborada por su equipo durante más de un año, que buscaba ponerla en funcionamiento "para el bien de la ciudad" (1990). Era una decisión ya tomada, suficientemente consultada en las altas esferas urbanas y políticas, que el burgomaestre esperaba mejorar con las contribuciones técnicas de los concejales y funcionarios de nivel jerárquico municipal.

El concejo tenía que conocer la propuesta de distrito metropolitano, mejorarla hasta donde fuera posible, consentirla y remitirla al presidente de la República, con quien el alcalde había acordado su apoyo, y que este, a su vez, la presentara al Congreso Nacional para su tratamiento, aprobación y puesta en vigencia. Era una propuesta gestada entre los estudios técnicos de sustento del Plan Distrito Metropolitano, que fue asumida por el alcalde y convertida, en actitud pragmática, en consenso del Cabildo Municipal, pues se buscaban resultados relativa- 
mente rápidos para controlar la expansión de la ciudad. Fue el talante que marcó el ambiente de las tres sesiones extraordinarias en las que el Concejo Municipal trató el proyecto de distrito metropolitano. Desde el comienzo el alcalde, con un estilo amistoso y directo, planteó el sentido de lo se esperaba hiciera el concejo:

pero puede ser que administrativamente discrepemos de lo que el Concejo pueda pensar, y en ese sentido nosotros por responsabilidad tendríamos que seguir empujando nuestra idea, porque no es algo que se va a someter a votación, lo que se trata es de que consideremos el proyecto, lo observemos, lo mejoremos y luego lo mandemos. (9-10)

Suficientes argumentos administrativos, urbanísticos y políticos sobre el desordenado crecimiento urbano de la ciudad fundamentaban la pertinencia de que el municipio asumiera la condición metropolitana, respaldados, además, en la nutrida información producida en los estudios de sustento del Plan Distrito Metropolitano que se elaboraba en esos días. La primera consideración con la que el burgomaestre abrió la presentación fue el parangón con las grandes capitales del mundo, colocando de partida un mensaje prescriptivo de nivel superior como una condición a emular,

a través de experiencias con otras ciudades que van creciendo, que han crecido más rápido que Quito, hemos visto que así funciona, no hablemos de ciudades, de países desarrollados como [...] Londres, París o Madrid en donde todas las capitales funcionan. [...] Las capitales funcionan como distritos metropolitanos. [...] Ya en ciudades más similares a nosotros, este procedimiento también se ha formulado, se ha establecido, existen por ejemplo en Bogotá, existe en Lima, existe en Santiago, existe en Buenos Aires, en distintas fórmulas. (4)

Hubo un sentido práctico en las palabras del alcalde, en cuanto a que, si ya se desarrollaron las regulaciones metropolitanas en otras ciudades, habría que aprender de ellas, aprovechar la experiencia existente y adaptarla a la medida de la ciudad. No obstante, tal como se dio el desenlace en las sesiones del cabildo, tratándose de una decisión ya tomada, cuya presentación solo tenía el propósito de mejorarla, el sentido prescriptivo marcó el ambiente para su consideración. 
Es que los dispositivos de la hegemonía cultural de la modernidad urbana son de carácter sistémico, funcionan por igual para el conjunto de actores y roles en el sistema nacional e internacional. Operan a escala del sistema mundo. El deseo de emulación de la riqueza y el estilo de vida urbano, estimulado desde la cima de las clases altas de la ciudad, se esparce descendentemente entre los estratos de la sociedad urbana. Las imágenes y simbolismos urbanos moran en las cúspides sociales de las metrópolis cosmopolitas, en la cumbre de los sistemas urbanos capitalistas, moldeando las aspiraciones urbanísticas en las demás ciudades periféricas para despertar el deseo de asemejarse a ellas.

El impulso por la emulación de los privilegios urbanos se replica por igual en las grandes ciudades occidentales, en las ciudades latinoamericanas, en las pequeñas y medianas ciudades andinas, en las sociedades urbanas del centro y la periferia. Se transmite por los conductos del sistema moderno colonial, cohesionando a la sociedad en la aspiración de igualdad. Es la práctica de la hegemonía cultural de la ciudad como uno de los espacios institucionales de la modernidad capitalista (Pipitone 2003).

Compararse con las ciudades extranjeras, para valorar la propia, es una constante en la cultura política quiteña. Entrado el siglo XIX los imaginarios urbanos continuaban enraizados en las miradas a los modelos coloniales, las ciudades andinas fueron valoradas según la horma de las ciudades europeas; no según sus propios procesos y funciones en el Estado-nación (Kingman y Bedón 2014, 31), sino tomando como referencia a las ciudades europeas ante las cuales las ciudades andinas eran valoradas como urbes de tercer orden. En la época contemporánea, sombras de estos imaginarios urbanos están en varios ámbitos de la vida local — como se expondrá en el capítulo-. Adoptar el distrito metropolitano en Quito fue para parecerse a las grandes ciudades metropolitanas del mundo moderno que así funcionan, fue el mensaje inaugural del proceso metropolitano quiteño, cuestión que, más allá del símil, fue pertinente para enfrentar la complejidad de la gestión municipal de una ciudad en expansión.

El proyecto de distrito metropolitano implicaba incluir un nuevo nivel en la división política-administrativa del Estado ecuatoriano: el 
metropolitano dentro de lo cantonal. No una equivalencia sino una jurisdicción especial que cumplía requisitos de tamaño, población y economía, aplicable únicamente a las ciudades de Quito y eventualmente Guayaquil. Requería una reforma de la Constitución, por lo que el proyecto de distrito metropolitano debía ir acompañado del respectivo proyecto de su reforma (Acta-E 1990, 15-6).

El modelo que se proponía era un distrito metropolitano con una opción distinta a la de provincia, cantón y parroquia. La autoridad correspondería al “Concejo y Alcalde Metropolitanos”, quienes definirían y ejecutarían la administración seccional correspondiente, asumiendo las funciones que la ley le asigna al municipio y eventualmente los atribuidos al Consejo Provincial, que tendría menos injerencia en el primero.

La administración metropolitana tendría dos modalidades combinadas: la desconcentración de las funciones ejecutivas por medio de las administraciones zonales subordinadas al alcalde, y coordinadas por un "administrador general del distrito", un "gran gerente de la maquinaria de la administración municipal" (17), convertido en el gerente de la ciudad; y la descentralización al interior del distrito, transfiriendo competencias municipales a las empresas metropolitanas que se crearían para la prestación de servicios.

El propósito del proyecto de distrito metropolitano fue, desde el inicio, "integrar" el territorio urbano del área metropolitana a la dinámica de expansión urbana que estaba controlada, direccionada, por los negocios inmobiliarios; aunque esto no se expresaba directamente en la propuesta, era claro que se trataba de un proyecto excluyente con las zonas rurales. Se privilegiaba el modelo de expansión urbana y su proyección futura, a treinta o cuarenta años, como áreas de reserva y consolidación del capital inmobiliario.

De modo explícito, se planteó el carácter urbano del proyecto del distrito metropolitano en el que las áreas rurales distantes y con dificultades de acceso no cabían, deberían separarse del distrito metropolitano, planteándose ineludiblemente el desprendimiento territorial con la conformación de nuevos cantones excluidos del proyecto metropolitano. En este sentido la exposición del asesor Wray fue clara: 
Para integrar el territorio distrital se ha tenido fundamentalmente en cuenta lo que podría definirse como el área de influencia inmediata de la ciudad de Quito, es decir que es un área eminentemente urbana que aunque en el momento no sea un área urbana ya, ciertamente está previsto su desarrollo con fines urbanos, eso implica recortar el territorio del cantón Quito, es decir disminuirlo para homogenizar los problemas y por consiguiente las soluciones y concentrar los recursos allí. La intención inicial fue que con el territorio restante, aquel territorio del cantón que no se integraba al distrito metropolitano, se pudiera organizar otros tantos cantones. (18)

El desprendimiento territorial para la conformación del distrito metropolitano venía preparando el municipio quiteño en consulta con la Comisión de Límites del Congreso y la Dirección de Límites del Ministerio de Gobierno, que revisaban las posibilidades de secesión de aquellas parroquias rurales del cantón Quito que no entrarían en el distrito metropolitano. Cualquier decisión afectaría la delimitación de la provincia de Pichincha, que arrastraba un viejo problema de "zonas no delimitadas" en los límites occidentales, así como tensiones con el cantón Santo Domingo de los Colorados, antigua parroquia rural del cantón Quito que, en julio de 1967, se conformó en un nuevo cantón con el mismo nombre, dentro del cual también había fuerzas que pugnaban por su provincialización, que ocurriría casi cuarenta años después con la conformación de la provincia de Santo Domingo de los Tsáchilas en 2009.

En la primera Sesión Extraordinaria del Cabildo, de la exposición de Fernando Carrión — por entonces director de Planificación del municipio de Quito- basada en los estudios preliminares de la estructura espacial metropolitana (IMQ 1992), quedaba claro que las modificaciones espaciales solo se harían dentro del territorio del cantón Quito. Argumentó que la propuesta mantenía la división política de parroquias urbanas y rurales, pues, con base en la pertinencia de la historia y tradiciones identitarias de sus habitantes, se consideró la estructura poblacional del distrito y se fijaron sus límites geográficos, que incluirían las áreas de protección natural y reservas ambientales (Acta-E 1990, 32-4). No obstante, afirmó que no era fácil esclarecer cuáles serían las parroquias rurales que se desprenderían, y se plantearon varias opciones. 
En el nivel de la provincia de Pichincha, explicó, se barajaron tres opciones: la primera, el distrito metropolitano emplazado en la totalidad del "área serrana del cantón Quito", dentro de una "nueva provincia” que correspondería a la franja occidental; la segunda, "dos provincias": la de Pichincha recortada, una nueva occidental y en el "medio el distrito metropolitano"; la tercera, "mantener la provincia de Pichincha” con sus actuales límites, y en su área central localizar el distrito metropolitano (35). La tercera opción fue la elegida para la conversión de cantón a distrito metropolitano.

En cuanto a los cantones que se formarían con el desprendimiento territorial, las opciones eran la formación de "tres nuevos cantones", porque esos territorios reúnen los requisitos que exige la ley para formarlos, excepto en uno de los lugares que no lograba el mínimo de habitantes; la segunda opción era "repartir" los territorios desprendidos en los "dos cantones ya existentes y en el distrito metropolitano"; la tercera, formar dos nuevos cantones en la franja occidental, a los cuales ya se les había bautizado entretanto con los nombres de Galo Plaza y Jaime Roldós. Quedaba un área de "difícil" ubicación: la parroquia rural San José de Minas, que se proponía pasar al cantón Pedro Moncayo (36).

Asimismo, explicó que otras opciones que se consideraron fueron: hacia el sur del distrito la posibilidad de hacer una "mancomunidad con el cantón Rumiñahui", o que en un "plebiscito" su población decidiera la pertenencia al distrito o al cantón Rumiñahui. También hubo propuestas de "pasar" los cantones del norte del distrito a la provincia de Imbabura, y los del sur a la provincia de Cotopaxi, pero eso significaba "atomizar" la provincia de Pichincha, por lo que se descartaron esas opciones para mantener los actuales límites provinciales e integrar San José de Minas al distrito metropolitano (32-8). De todos modos, quedaba la inquietud de cuál sería la capital de la provincia de Pichincha.

En la práctica, el desprendimiento de las tres parroquias rurales del noroccidente del cantón Quito ocurrió casi inmediatamente, dos se dieron antes de la aprobación de la LRDMQ. El municipio capitalino, conjuntamente con el Consejo Provincial de Pichincha que ejecutaba el proyecto Desarrollo Rural Integral (DRI) en la misma zona, promovió 
el desprendimiento de las parroquias rurales y la creación de los nuevos cantones, con lo que el 14 de febrero de 1991 se formó el cantón San Miguel de los Bancos, el 28 de enero de 1992 se creó el cantón Pedro Vicente Maldonado y el 1 de abril de 1996 se fundó el cantón Puerto Quito (AME 2007, 4).

La exposición del asesor financiero René Sánchez, teñida de tecnicismos acerca de la normativa presupuestaria, tributaria y contable pública, mostró la necesidad de una reforma tributaria, imprescindible en el proyecto de distrito metropolitano. Explicó, en detalle, las necesarias adecuaciones que tendría que asumir el distrito metropolitano para asegurar los ingresos municipales, con reformas al impuesto predial, la actualización de la tabla de exoneraciones tributarias a los bienes públicos y privados; igualmente a los impuestos de transferencia de dominio de bienes muebles e inmuebles, y sus exoneraciones.

Arguyó también sobre la reforma a las tasas de espectáculos, patentes, juego y contribuciones especiales, y de los ingresos no tributarios, multas y sanciones. Planteó que la reforma tributaria era inevitable para mantener la buena marcha del municipio, "así no se produzca la aprobación de la ley del distrito metropolitano" (Acta-E 1990, 32). En la argumentación sobre los impuestos prediales, tal vez sin intención, evidenció una visión estereotipada sobre los habitantes de la ciudad cuando afirmó que:

La existencia de un impuesto de este orden ha impedido que los avalúos se actualicen, se lleve a lo largo de los años una actualización de avalúos porque el impuesto resultaba ser un dogal que impedía esta actualización y el Municipio no puede vivir de mentiras, tiene que actualizar el catastro, tiene que saber el país cuánto es lo que vale cada ciudadano, cuánto es lo que vale su predio. (22)

No se trataba de una exposición de temas contables en un auditorio común, sino el fundamento, en materia tributaria, del proyecto de distrito metropolitano explicado a las autoridades de la ciudad, de ahí el lenguaje; las expresiones entretejidas en la disquisición revelaban el significado que les atribuyen a las personas y a las instituciones quienes, en este caso, formularon el proyecto de distrito metropolitano. Las palabras y los modismos cuando forman parte de discursos enun- 
ciativos contienen, figurativamente, relaciones de "poder instituidas" que existen socialmente o son reconocidos como "sistemas simbólicos sancionados", expresan conexiones entre significantes y "conminaciones o incitaciones de hacer o no hacer" (Castoriadis 2010). Las palabras, dice Castoriadis, cuando forman parte del corpus del derecho contienen reglas con consecuencias en el funcionamiento de la economía, o son apropiadas por otras reglas que la hacen funcionar (192). Las palabras son y tienen consecuencias simbólicas.

Las alegorías retóricas, los modismos o las maneras cotidianas de expresión acerca de los hechos, las personas y las instituciones no son indiferentes de los valores ni se usan como recursos asépticos, contienen preceptos ideológicos que no están completamente demarcados, por lo que pueden adquirir distintas connotaciones según el contexto, la situación o el mensaje. Al no ser arbitrarias, las palabras se usan con alguna intención enunciativa, se remiten a un "código de significados", a un imaginario social. El simbolismo del lenguaje, como dice Castoriadis, "no es ni puede ser neutro", no hace sus signos al azar, ni desde un pretendido punto cero, desde un signo cualquiera, los individuos siempre recurren a lenguajes constituidos y así confieren determinados sentidos a las palabras, a las expresiones, no lo hacen con una "libertad ilimitada", sino para "apropiarse de algo que se encuentra ahí" (193).

La expresión del asesor reveló una valoración moral institucional, una postura de poder, al colocar en calidad de precepto prescriptivo la propiedad privada del predio como condición del valor ciudadano, se es ciudadano por lo que se posee, las personas valen por lo que tienen, era el sentido de sus palabras. La jerarquía de la propiedad privada estaba en el núcleo de la argumentación tributaria del proyecto metropolitano para la ciudad, lo que excluía a más de un tercio de sus habitantes que no tenían vivienda, que eran y son parte del déficit de vivienda en la capital. No se les descartaba por el pago del impuesto predial, se les estaba segregando de la condición de ciudadanos, de personas con derechos individuales y libertades basadas en la propiedad privada.

Fortalecer la autonomía del gobierno metropolitano, ampliando su capacidad tributaria para nutrir el presupuesto municipal con ingre- 
sos propios, era el propósito de la reforma en ciernes. La autonomía metropolitana se entendía como algo más que ampliación de las facultades de recaudación tributaria municipal, se refería también al incremento de las atribuciones y competencias de la autoridad local para el ejercicio de la representación ciudadana en la urbe. En el marco de las relaciones del potencial gobierno multinivel y el Estado nacional, se buscaba que la corporación municipal, en calidad de autoridad del distrito metropolitano, adquiriera mayores rangos de decisión en el uso y destino de los recursos propios y de los obtenidos por transferencias estatales, conjuntamente con el aumento de las facultades ejecutivas y las competencias gubernamentales del alcalde metropolitano.

Los alcaldes precedentes, en los hechos, habían impuesto un estilo de gestión para la realización de las obras, maximizando la estructura municipal hasta donde la ley permitía con la autonomía municipal. Habían asumido una suerte de descentralización por delegación efectiva de roles a las entidades que conformaban el organismo edilicio, aunque la institucionalidad local no estuviera diseñada para ello. Durante décadas el municipio capitalino había incrementado sucesivamente los procedimientos institucionales, hasta el punto de congestionarse los trámites administrativos para la contratación pública y la ejecución de obras, al igual que en la prestación de servicios a los habitantes de la ciudad.

Como se señaló, la normativa se mostraba limitada, rígida, ante la compleja y cambiante realidad de la ciudad; era una normativa atrasada que respondía a la dinamia de la ciudad tradicional. Si bien se habían realizado algunas reformas a la normativa municipal, los cambios administrativos no estaban en sintonía con la evolución de la ciudad moderna; no era cuestión solo de ampliar las capacidades administrativas de las autoridades, sino también de adecuarlas conjuntamente con la estructura organizativa del municipio. Incrementar las capacidades de decisión y acción de las autoridades locales implicaba reformar la institucionalidad municipal en sintonía con el proyecto de distrito metropolitano.

Por más que se extendieran las atribuciones de las autoridades, no había la capacidad institucional para asumirlas, con lo que las facultades del alcalde estaban constreñidas a la organización del municipio. 
El alcalde seguía cumpliendo funciones de tipo honorífico en extremo burocratizadas, eran una mezcla de conductas señoriales patriarcales y rutinas burocráticas; si bien pertinentes para resolver ciertos problemas cotidianos de los habitantes de la urbe, su operatividad era herencia de un pasado teñido por las costumbres de la ciudad vecinal. El alcalde actuaba atrapado en procedimientos burocráticos y judiciales extendidos, abultados con la expansión estatal de las décadas precedentes, y aunque en el nivel nacional del Estado estos se estaban removiendo por la influencia de las políticas neoliberales de "achicar el Estado", en el nivel cantonal, en cambio, se mantenía estancados, inclusive en uso de la autonomía municipal se habían abultado.

Los procedimientos eran igualmente densos tanto para conceder hábeas corpus como para tramitar las becas estudiantiles o las situaciones laborales municipales, explicó el alcalde en su alocución al concejo (Acta-E 1990, 46-7). La gestión de la ciudad exigía ir para adelante, pero sus procedimientos se mantenían anclados al burocratismo del pasado. Con el proyecto de distrito metropolitano, el alcalde aspiraba a un cambio institucional que liberara el tiempo de la autoridad local para dedicarse a los asuntos trascendentales de la ciudad, no a las minucias burocráticas, para eso estaba la administración. Su visión de la organización municipal, planteada por uno de sus asesores externos, estaba enfocada en liberar el tiempo del alcalde y develaba abiertamente su carácter elitista, el que se sintetiza en lo dicho por el burgomaestre durante la sesión:

como él creía que debía organizarse la administración municipal, entonces mientras uno está más abajo, por ejemplo hablemos de un sector que hace el trabajo rutinario, no debe pensar mucho sino ejecutar una orden, pero conforme va subiendo debe tener más tiempo para pensar y menos tiempo para administrar, y cuando llega al alcalde debe destinar el setenta por ciento de su tiempo a pensar y el treinta por ciento a definir, porque la gran decisión siempre está arriba. Bueno yo me paso el noventa por ciento firmando y el diez por ciento pensando, esto es un absurdo. (48)

En las argumentaciones del burgomaestre con las que fundamentó el proyecto de distrito metropolitano, si bien hubo alusiones a la rea- 
lidad de la ciudad, a las empresas ahí afincadas, a las experiencias de las autoridades locales, y a las demandas de la población, estaban teñidas por el enredo de los procedimientos institucionales y la obsolescencia normativa que afectaban a los problemas de la ciudad. El mensaje detrás de sus palabras, aunque pertinente, estaba matizado por una perspectiva de que lo municipal había alcanzado el límite de la eficiencia, no funcionaba bien, mientras en otras latitudes había ejemplos a seguir.

El referente persuasivo en los argumentos del alcalde eran las ciudades extranjeras, los modelos de gobierno metropolitano de otras urbes y el desempeño de sus autoridades. Nuevamente, para ilustrar que la situación del alcalde de Quito era inadecuada a la realidad de la urbe, que demandaba la renovación de la gestión metropolitana, el burgomaestre recurrió a la comparación de lo que ocurría en otros lugares considerados emblemáticos, se refirió al estilo cosmopolita de lo que debería ser el alcalde cuando dijo que:

el que el señor Tedi Collec, alcalde de Jerusalén, que tiene veinticinco años de alcalde, el noventa por ciento del tiempo se pasa fuera de Jerusalén, ¿por qué? Porque él hace grandes relaciones públicas y consigue millones de dólares a través de las colonias judías, instituciones internacionales que producen un enorme beneficio a Jerusalén, y posiblemente él está en la decisión final de la planeación de la ciudad, y cómo debe dirigirse, asiste a esas reuniones, pone su punto de vista, ya son los administradores de la ciudad que siguen el manejo de la ciudad, y él el noventa por ciento pasa en ese asunto. (49)

La propuesta del alcalde era clara: que el burgomaestre dispusiera de más tiempo para dedicarse a los “asuntos grandes” de la ciudad y menos a las "menudencias" que absorben tiempo, pues la "tendencia natural" de la administración pública supone otorgarle mayor ejecutividad al alcalde para dedicarse a las cuestiones estratégicas, lo que conlleva que este, a su vez, delegue sus funciones en otros funcionarios municipales para asegurar la administración de la ciudad (49). Había que desbloquear el entrampamiento procedimental al que había llegado el municipio capitalino. 


\section{El debate municipal: Divergencias y consenso}

Una vez presentado el proyecto de distrito metropolitano por parte del alcalde y de sus asesores, se abrió el debate entre los concejales asistentes a la Sesión Extraordinaria. En las cortas intervenciones quedó claramente establecido el consenso en torno al proyecto, no hubo mayores observaciones a la propuesta que no fueran detalles de procedimiento, salvo la posición del concejal Rafael Quintero del FADI, quien ratificó el consenso del cabildo sobre el proyecto de distrito metropolitano, y planteó algunas observaciones de forma y contenido.

Argumentó que se trataba de una reforma al régimen de gobierno y administración de una región que incluye a la capital de la República, que le compete al cabildo porque se estaban creando nuevos cargos metropolitanos. Consideró que al proyecto de distrito metropolitano le incumbe auspiciar una mayor participación ciudadana en los asuntos del gobierno, para que sus habitantes se constituyan en "agentes activos en la discusión de los asuntos que se desarrollan en esa región”. Corroboró en mantener el principio de autonomía del gobierno seccional, con un "ejecutivo fuerte" asentado en una amplia "base democrática", y planteó considerar la pertinencia de la parroquia urbana como la unidad territorial y social de las nuevas zonas administrativas que proponía el proyecto, pues a su criterio se trataba de un nuevo esquema de distrito, parroquia y zonas administrativas que reemplazaría al anterior esquema de cantón, parroquias urbanas y rurales (39-42).

Luego de la exposición del concejal Quintero, el alcalde concluyó la sesión pidiendo que los concejales se reunieran con sus asesores de inmediato, en la sala de la Alcaldía, porque los asesores no eran funcionarios municipales y disponían de poco tiempo para que absolvieran las consultas técnicas y las aclaraciones necesarias, de modo que en la siguiente sesión expusieran sus criterios los representantes de los bloques de los partidos políticos (54). Convocó a continuar en la próxima sesión el tratamiento y aprobación del proyecto de distrito metropolitano.

La tónica en la siguiente sesión del Cabildo Municipal fue similar. Se ratificó el consenso total de los asistentes en el proyecto del distrito metropolitano, acompañado de breves observaciones a ciertos proce- 
dimientos administrativos, especialmente tributarios, y algún nivel de debate en torno a los criterios diferentes del concejal Rafael Quintero. Quien retomó la palabra y planteó que el proyecto fue "reclamado por el cabildo" para emitir razonamientos en un ámbito democrático, sobre "una reforma política que es la más importante que se haya presentado en toda la historia del Quito moderno", por lo que no puede reducirse su análisis al delegar a una comisión, sino que, conforme se acordó, los concejales representantes de los partidos políticos manifiesten sus planteamientos (Acta-O 1990, 7).

Después el alcalde corroboró que la mecánica no era someter a votación el proyecto, sino recoger las observaciones que lo mejoren, registrar todos los planteamientos y adjuntarlos al proyecto del distrito metropolitano, de modo que al presentarlo en el Congreso los legisladores tengan los puntos de vista de todos, los acuerdos y las divergencias, las posiciones de grupos y las individuales, y aclaró que la ejecución del proyecto no le correspondería a su administración, lo que permitía mayor libertad de opinión. Su planteamiento fue el siguiente:

En resumen, personalmente yo quisiera ser parte de una administración que propone este proyecto, pienso que es un proyecto vital y que todos ustedes quisieran hacerlo, qué va a pasar si no lo logramos hacer, lo cual es muy difícil, pero nada es imposible, en este mes y medio que nos falta para terminar esta parte, que quede para una futura etapa, donde muy posiblemente el próximo Congreso no pasa o se duerme. (9)

En una actitud realista con el tiempo de la política, el alcalde buscaba presentar el proyecto del distrito metropolitano en un Congreso Nacional a favor, por lo que instó al cabildo a su aprobación. Afirmó que había unanimidad en el cabildo sobre la idea del distrito metropolitano, las divergencias estaban en torno a los criterios de cómo instrumentarlo, en cómo ponerle en práctica, por lo que propuso debatir solo aquellos aspectos en los que hubiera discrepancias (11).

En medio de recurrentes pedidos de "punto de orden", por parte de varios concejales que requerían esclarecer la mecánica del debate, el concejal Quintero continuó con su exposición. Explicó que la LRM tenía un vacío ante el "problema de la dirección político-administrativa de los 
grandes centros urbanos", vacío que se compensa con el proyecto del distrito metropolitano, con lo que los grandes centros urbanos que sobrepasan el millón de habitantes requieren esta adecuación; en el caso del cantón Quito, aseveró, no puede seguirse administrando centralizadamente.

Argumentó que el "concepto de distrito metropolitano permite subdividir una región" para fines de la administración municipal, y nuevamente propuso que debía "darse vida política y cívica" a la parroquia, con lo que el distrito metropolitano estaría integrado por "las parroquias urbanas de una gran urbe y su zona de influencia”, en las que se conformarían "cabildos parroquiales o juntas parroquiales urbanas" con capacidad administrativa, con deberes y obligaciones, y conformadas con "criterios de representación popular y democrática" (17-8). En síntesis propuso que

el gobierno del Distrito Metropolitano significa una reforma a lo que actualmente es el Cabildo, para darle mayor representación de los diversos sectores del Distrito y permitir que el Cabildo Metropolitano sea una instancia en la que se discutan los más diversos problemas que afectan a la ciudad y a su zona de influencia. (18)

Las críticas al proyecto del distrito metropolitano del concejal Quintero apuntaron a las distintas modificaciones de los artículos que a su juicio daban lugar a "una merma de las atribuciones del Concejo Municipal", y que "elevaban enormemente las atribuciones del Alcalde Metropolitano", con la creación de "esa especie de gerente general, administrador general designado por el Concejo pero que no puede ser removido por él", algo improcedente dijo, que amplía "enormemente las funciones y atribuciones al ejecutivo municipal" (26-7).

Sobre los directores zonales señaló que, aunque en el proyecto se evita decirlo, tienen poder político porque tienen capacidades para dirigir los servicios municipales en las zonas del distrito, administrar sus dependencias, ejecutar sus planes; insistió en que tienen capacidades políticas y no son elegidos, tampoco tienen responsabilidades con el concejo. Igualmente criticó a los cabildos zonales propuestos por el proyecto, señalando que en la práctica serían una especie "de comités 
pro mejoras", con listados de obras (28-9). Sintetizó sus críticas en los siguientes términos:

en primer lugar, en el proyecto persisten núcleos de poder no elegidos; es decir, se rompe con el principio electivo y se puede dar paso a la creación de núcleos autoritarios a futuro. En segundo lugar, como conclusión, en este proyecto se da continuidad a la tendencia corporativa y corporativizante en la política y en el sistema político ecuatoriano en cuanto se refiere a la representación política [...]. En tercer lugar, en el proyecto se está subordinando a la sociedad civil a un verticalismo de Estado, considerado el municipio como un aparato del Estado. En cuarto lugar, se robustece, se hace crecer tanto al poder ejecutivo metropolitano que podría ponerse en vigencia un proyecto autoritario de quienes, logrando acceder a la cúpula de este aparato estatal, podrían generar procesos de desestabilización al régimen político democrático. En síntesis, señor alcalde, la perspectiva de esta propuesta, a nuestra comprensión, privilegia el orden antes que el cambio y por esta razón el FADI se opone a esta perspectiva y tiene algunas propuestas que hacer con relación al proyecto de distrito metropolitano. (29-30)

Concluyó su exposición ratificando que sí estaba de acuerdo con la pertinencia de ir hacia el distrito metropolitano, y propuso que debería realizarse un capítulo especial de la LRM que no rompa las normas contempladas en ella, que esté relacionado con el distrito metropolitano y no sea un régimen especial.

El concejal Juan Campaña, en nombre del bloque de la ID, ratificó el apoyo de los concejales al proyecto de distrito metropolitano. Señaló que sería adecuado que se ajustara a las necesidades del ejecutivo y legislativo municipales, "si bien el proyecto tiene buenas intenciones, hay que perfeccionar algunas cuestiones", afirmó. Entre estas, propuso que se debía motivar el consenso entre los sectores de la comunidad, mediante "la realización de foros, reuniones, seminarios académicos y políticos y comunitarios, en razón de tratarse de un proyecto de interés común”. Destacó la importancia del capítulo de los derechos de los vecinos y la participación ciudadana (32).

Coincidió con la observación de que en el proyecto de distrito metropolitano se reducen las atribuciones del concejo y se amplían las 
del ejecutivo municipal, y argumentó acerca del rol de los concejales en el nuevo esquema de funciones, en el que se desdibuja el contacto con la ciudadanía, aseveró:

Cuando, por ejemplo, se hace cualquier tipo de entrevista a un ciudadano común, se le pregunta y qué espera usted del concejal, inmediatamente responde, espera que solucionen los problemas acuciantes de mi sector; es decir, se ha enraizado en la conciencia de la comunidad de que el concejal es quien debe generar los servicios hacia los sectores comunitarios, no es como se pretende en el proyecto el presidente o quien va a presidir los cabildos zonales [...], no pueden presidir si ellos no nacieron de la voluntad popular. (34)

En las expresiones del concejal Campaña era visible que, tras la imagen del pragmatismo ciudadano, se encontraba enraizada la práctica del clientelismo local, por la que operaban las autoridades como eslabones de un sistema político que permuta lealtades sociales por obras y servicios urbanos, y que es asumido como una atribución propia de las autoridades electas, eso no le correspondía a un funcionario designado, menos aún que se concentre en las administraciones zonales. Campaña propuso dosificar las atribuciones del concejo y del alcalde, y mantener la capacidad del concejo de remover a los funcionarios designados.

Se refirió a la reforma tributaria del proyecto de distrito metropolitano argumentando la validez del principio de que "todos los ciudadanos debemos contribuir con la administración municipal”, hay que evitar el "paternalismo de recibir obras y servicios sin fortalecer las finanzas municipales", y planteó priorizar las acciones municipales en los sectores pobres de la ciudad (36).

En su intervención el concejal Rosendo Jara, en nombre del bloque de la DP, reconoció el esfuerzo del alcalde al proponer el proyecto de distrito metropolitano, y tras declararle su respaldo, expresó sus desacuerdos con los criterios del concejal Rafael Quintero. Sobre el tema de los directores de las administraciones zonales argumentó que no son divisiones geográficas ni administrativas, sino una manera de tratar las partes de "una misma unidad que es el área, espacio y sociedad metropolitana”, si se tratan como partes separadas: 
o semiseparadas con elecciones directas de los representantes de los administradores zonales podría fomentarse un micro regionalismo, que la creación de entidades de presión en todo caso pueden contraponerse entre sí, llamamos entidades de presión a que el administrador y los Cabildos de la Zona Sur pueden entrar en contraposición con los de la Zona Norte, pensamos que estratificar las zonas con diferentes capacidades económicas, y por lo tanto diferencias de capacidades de solución de sus problemas, sería negativo para el tratamiento integral de Quito Metropolitano. (36-7)

La merma de funciones aludidas, con la omisión de determinados artículos, se compensan en otros artículos explicó, y ratificó la pertinencia de los directores de las administraciones zonales. Comentó la idea de los cabildos zonales porque se contrapone a "lo propuesto por el mismo concejal Quintero, en cuanto a su propuesta para la creación del Concejo Metropolitano", no caben, señaló, "Concejos menores que tengan el mismo poder y que estén representados por los cabildos" (38). Concluyó su intervención indicando que igualmente se deben mejorar, en la propuesta, los artículos referidos a las relaciones entre el alcalde y el concejo.

A su turno, el concejal Luis Rengifo, en nombre del bloque del PSC, expresó estar "plenamente de acuerdo" con el proyecto de distrito metropolitano, explicó que a su entender el proyecto constaba de dos partes: lo administrativo y lo tributario, y arguyó que solo se ha explicado lo administrativo, no lo tributario. Coincidió con la exposición del concejal Quintero en la merma de atribuciones al concejo, señalando que, de las 49 atribuciones consignadas en la LRM, solo quedaron dieciocho en el proyecto. Igualmente, en que se elevan las atribuciones del alcalde y del procurador metropolitano, a este último se le da representación jurídica, y comentó que para ir a los cabildos zonales y parroquiales habría que hacer una reforma a la ley de elecciones. Señaló que nada se ha dicho del Cabildo Ampliado (39).

Criticó la exposición del asesor Sánchez relativa a los impuestos en el proyecto, dijo que la afirmación de que contribuirán quienes más tienen es relativo, porque si se crean impuestos a los que más tienen, las empresas, los que acaban pagando son los consumidores y usuarios, es decir "redunda en contra del pueblo", porque los dueños de las empresas 
lo que hacen es subir los precios (40). Comentó en detalle la propuesta de impuestos y afirmó que elevarlos encarecería la vida en la ciudad, arguyó que la capital del país se hará tan cara como las capitales europeas. Comparó la propuesta tributaria con la normativa municipal vigente, y concluyó que:

de este aspecto tributario se desprende que se va a crear o se aumenta una cantidad de impuestos que prácticamente llevaría a quienes habitan en el Distrito Metropolitano, a que no estarían en la capacidad de financiar la constitución, la conformación del Distrito Metropolitano [...], es imperioso y fundamental un estudio más detallado, más concienzudo a fin de que el aspecto tributario no sea una carga tremenda para quienes vamos a habitar en el Distrito Metropolitano. (41)

Por su lado, el concejal Jaime Ruiz del PSE también expresó su apoyo al proyecto de distrito metropolitano. Arguyó que más allá de los aspectos administrativos, tributarios y limítrofes no se ha considerado lo que es esencial a un gobierno seccional: la "participación de la comunidad". Explicó que se requiere mayor claridad sobre la delimitación de las zonas centrales y suburbanas en el proyecto, y que debe esclarecerse mejor lo de las parroquias urbanas y suburbanas en el territorio del distrito metropolitano.

Coincidió en que se limitan las facultades del concejo y, aunque la centralización de las funciones administrativas sigue un criterio de eficiencia, deben ampliarse las facultades del concejo y precisarlas con la elaboración de un reglamento de funcionamiento del Concejo Metropolitano. Indicó también que hay que establecer mejor las funciones de todos los organismos que van a ser parte de la administración metropolitana. Igualmente consideró que el mecanismo para la representación de las subzonas metropolitanas es inadecuado (43-5). Argumentó que el proyecto debe estimular la participación para que la gente no siga siendo un sujeto pasivo en lo que tiene que ver con la administración de "su zona", propuso que

para el funcionamiento del Concejo Metropolitano que, a mi juicio, debería estar integrado no solo por el alcalde y los quince concejales, sino también debería estar integrado por los alcaldes distritales menores que 
deberían ser nombrados por la comunidad y que incluso se podría pensar en dos instancias: una instancia regular de funcionamiento común, el que ocurre ahora en el Concejo de Quito; y una instancia un poquito mayor que permita un Cabildo Distrital ampliado. (45-6)

Advirtió que la elección de cabildos parroquiales es impracticable, que la reforma tributaria requiere de un estudio socioeconómico para establecer las diferencias en el pago de tributos, y que igualmente falta profundizar los estudios técnicos para delimitar el distrito metropolitano.

A su turno, el concejal Luis López se refirió al objetivo del proyecto, dijo que es una nueva estructura de gobierno local adecuada a la situación que vive en la actualidad Quito y su zona de influencia, pues se busca eficiencia en el manejo del territorio; sin embargo, hay que pensar más allá de la eficiencia. Cuestionó hasta dónde el proyecto pretende enfrentar "el problema del desarrollo de este sector en relación al desarrollo del país”, ese es el carácter de la reforma política propuesta (50).

Se refirió a la delimitación territorial, más allá de las parroquias a desprenderse y los eventuales plebiscitos en cantones vecinos, se trata del mismo territorio, "nos debe preocupar su futuro a veinte o treinta años”, por lo que la propuesta debería tener esa proyección, aunque la legislación no se adecúa y podríamos enfrentar un crecimiento urbano sin control, advirtió (51). Sobre la estructura de gobierno, dijo no estar de acuerdo: "un tanto rara de cabildos en parroquias rurales y no en las zonas urbanas", porque somete la representación ciudadana a funcionarios administrativos, aunque hay que reconocer las formas de organización y los liderazgos propios.

Opinó que se debe permitir la participación de la ciudadanía y no que esté sometida al clientelismo de los funcionarios municipales, puede haber mecanismos como la asamblea distrital o el cabildo ampliado que permitan acceder a las decisiones de la administración municipal. Reconoció la importancia de la reforma tributaria para fortalecer las finanzas municipales, si bien en este campo también se busca eficiencia, le preocupaba que se base en un catastro multifinalitario que no dispone el municipio, por lo que propuso que se trate por separado, en otro 
momento, la reforma tributaria, mientras tanto se puede funcionar bajo la cobertura de la LRM (54).

Finalmente, el concejal Rafael Reyes se refirió a dos aspectos que le preocupaban: el tributario y el administrativo, en lo demás dijo que estaba de acuerdo. Consideró que lo de los administradores zonales debe ser meditado con más atención, para que no se crucen con la representación del electorado, también consideró que lo tributario debería tratarse por separado del proyecto de distrito metropolitano. Y sobre los límites del distrito que consideraba estaban relacionados con lo tributario, dijo que habría que tratar de otorgar algún beneficio tributario a las tierras menos productivas del distrito (55).

Concluidas las exposiciones, el alcalde planteó que "producir algo nuevo no es fácil”. Se revisaron las experiencias de varios países, en todos los casos se hacen de distintas maneras, por lo que "con base en las buenas y malas experiencias hemos ido elaborando el proyecto", comprendía que los puntos de vista de los concejales y el alcalde no siempre son coincidentes, aunque el fin sea el mismo. Explicó que el proyecto fue trabajado con los asesores, el síndico, la Dirección de Planificación "que ha sido una especie de eje del proyecto" y la Dirección Financiera. Es un proyecto pensado para el futuro, para el manejo de la ciudad en el año 2018, e insistió en que así funcionan las grandes urbes capitales del norte y de los países vecinos (59-60).

El alcalde declaró que alguien debe hacerse cargo del manejo de la ciudad, que Quito en el presente todavía tiene posibilidad de controlar el crecimiento, pero en el futuro los alcaldes lucharán con desventaja, pues al solucionar los problemas en los barrios se está incentivando a que otras personas vengan a la ciudad, y no está en capacidad de absorber la mano de obra. Examinó con realismo la gestión municipal, indicando que "si nosotros no le cobramos un sucre a una persona por tener su casa por más pequeña que sea, estamos por un lado solucionando un problema de justicia, por otro incentivando a crear un problema, eso es lo que tenemos que pensar" (61), afirmó.

Aclaró que el proyecto de distrito metropolitano buscaba el control del desarrollo futuro de los valles, del sur y norte de la ciudad, del 
bosque protector que permite respirar en medio de la polución, "tenemos grados de envenenamiento que nosotros creemos que no lo vivimos"; este tipo de cosas son las que hay que enfrentar, sostuvo. Planteó su visión de conducir el crecimiento urbano para "sacar poco a poco la ciudad hacia el suburbio planificadamente, eso existe en todas las ciudades que crecen". Aclaró que la situación de la ciudad no amerita mayores cambios, con la administración existente es suficiente, "aun así debemos preocuparnos de nuestra futura responsabilidad" (61).

Consideró "racionales" los planteamientos de los concejales. Aceptó que había ciertos aspectos del proyecto que se debían mejorar, algunos errores a rectificar, palabras que se omitieron, puntualizar el manejo de lo metropolitano, que eso no era problema; pero que la idea de alcaldes distritales planteada por algunos concejales no era admisible:

En cuanto a los jefes zonales, por lo menos la idea de la Administración no es crear alcaldes secundarios, zonales, o lo que sea, eso es inconveniente simplemente por razones políticas, es un caos organizado, la experiencia de otros países me lo dice y en ese punto sí estaría firme en que no puede producirse el alcalde zonal. (62)

Sobre las observaciones al jefe distrital, explicó que se trataba de que funcionaran las cinco administraciones zonales, su director no tiene ninguna atribución mayor al alcalde, el responsable es el alcalde no el director, y la ley establece las sanciones a los directores designados por el concejo. En cuanto al jefe suburbano que contempla el proyecto, es acertada la observación de que no cabría que un jefe zonal sea la cabeza de un cabildo parroquial, es una buena observación que debe ajustarse, señaló.

Acerca de los impuestos habló en detalle de la necesidad de incrementar los ingresos municipales, de disminuir la dependencia fiscal del Gobierno central, indicó es una presión en cadena: los barrios presionan por obras a los concejales, estos le presionan al alcalde y las obras se hacen con dinero, pero la gente es tolerante cuando no hay dinero y piden que se les haga las obras en el próximo año (62-3). El alcalde señaló que las obras y los impuestos van juntos, si no se suben los impuestos no se hacen las obras, lo que tiene un costo político, la ciudadanía acepta cuando ve que hay obras. La reforma tributaria es impostergable, 
hay que hacerla junto con un catastro moderno que permita subir los impuestos proporcionalmente, porque si no hay ingresos prediales no hay obras:

yo les digo a ustedes señores concejales por experiencia, la ciudadanía al final lo que quiere son obras, le duele pagar, molesta; pero a la final si hay obra, paga y eso tiene un costo, ustedes ven que a pesar de eso el costo no ha sido mayor, la ciudadanía nos ha aceptado y hasta el momento así ha pasado, esa es la filosofía. (65)

El alcalde pidió a sus asesores que ampliaran la explicación y respondieran a las inquietudes de los concejales. El asesor Alberto Wray señaló que el eje era el proyecto de reforma constitucional, porque el distrito metropolitano es una unidad distinta a las otras ya existentes dentro del régimen de administración seccional, está por fuera de la división de provincias, cantones y parroquias, no puede estar regido por la LRM, sino por una ley especial que considere la normativa municipal. Argumentó que es una unidad distinta, dentro del distrito metropolitano cumple los fines de los Concejos Municipales y los Consejos Provinciales, de ambos, se administra y gobierna por un alcalde y un concejo, por lo que no hay distinciones conceptuales (69-71).

Precisó que el concejo tiene el mismo número de concejales según la población y la ley, y en el proyecto no se restan derechos ni facultades a los concejales. Explicó que la relación entre el concejo y el alcalde no depende del número de atribuciones, sino de su naturaleza y su formulación, hay una jurisdicción entre las funciones del alcalde y el concejo:

¿Cuál es esa línea demarcatoria? El alcalde se ocupa de la administración, el Concejo se ocupa de definir las políticas, por eso aprueba los planes, legisla y ejerce una actividad de fiscalización, de control sobre las actividades de la Administración. En grandes líneas, esas son las tres atribuciones fundamentales que se ha querido reservar para el Concejo. (71)

Explicó que se agruparon las funciones de acuerdo con estos criterios, las que son propias del concejo y las que corresponden al alcalde, aunque en el proyecto va más allá de la LRM, eliminándose del texto lo que llegaría a ser ley, se prevé más bien en la estructura administrativa 
para que el concejo mediante ordenanza regule ese funcionamiento, sin sujetarse a la limitación que existiría si todo se incorpora en la ley:

una regulación demasiado minuciosa en la propia ley implicaría que hacia el futuro tendría que cambiarse la ley con mucha más frecuencia, parece más fácil cambiar las ordenanzas, aquí en el seno del Concejo, que cambiar la ley; a ese mismo criterio responde el hecho de que no se haya incorporado en la ley, por ejemplo la delimitación de las zonas metropolitanas, no porque no se tenga los estudios o porque no se ha profundizado en ello, sino porque técnicamente, desde el punto de vista de la técnica legislativa, se considera inadecuado dejar eso plasmado en la ley, precisamente para que la realidad cambiante de una dinamia urbana muy veloz no supere a la lentitud propia de un órgano legislativo como es el Congreso. (72)

Argumentó que la distribución del territorio en unidades administrativas menores, en zonas metropolitanas urbanas y suburbanas, y las parroquias dentro de cada zona, implica un administrador general y un administrador en cada zona, es "algo típicamente administrativo", sus funciones dependen exclusivamente de lo que el alcalde quiera delegarle, no es lógico, dijo, que estos funcionarios respondan a elecciones, sino que sean designados por quien les delega funciones; y afirmó que efectivamente no es esencial en el proyecto que estos directores presidan los cabildos parroquiales, le corresponde al propio cabildo elegir quién lo preside, solo puede removerlos el alcalde, que es quien los eligió (75).

Acerca de que en las zonas exista un cabildo zonal, dijo que es una "apreciación política" que corresponde a su implementación, "podría ocurrir o no, de eso no me compete opinar", dijo. En lo relativo a la delimitación territorial, el punto de partida fue lo que ocurriría en la dinámica urbana de estas zonas, con la conversión a distrito metropolitano, aseveró que

lo que tenía que preocupar al Concejo del cantón Quito, era fundamentalmente lo que iba a acontecerle como consecuencia de su transformación en Distrito Metropolitano, como bien se observaba esto, implicaba, fundamentalmente, no la incorporación de nuevas zonas, y voy a referirme al por qué se consideró de que esto no era conveniente introducir en el proyecto, sino más bien a la desmembración de ciertas zonas que 
de acuerdo a las apreciaciones de Planificación, no tenían perspectivas urbanas en un lapso mediano. (75)

Algunos concejales, en el uso de la palabra, insistieron en la posibilidad de que los directores zonales pudieran ser electos con la misma papeleta del alcalde, según las filiaciones políticas, a lo que el alcalde Paz nuevamente aclaró:

Solamente como una explicación, yo creo que sería darle un poder y que en nuestro proyecto no lo queremos dar, queremos darle las atribuciones que el alcalde crea que son necesarias para que pueda administrarse de la mejor manera y no debería darse atribuciones que mañana vayan a interferir con la acción de los directores, eso ya sería muy grave, entonces más bien ahí se estaría dando un poder mucho más del que nosotros pretenderíamos darle. (85)

El asesor René Sánchez consideró que las opiniones vertidas sobre la reforma tributaria propuesta eran "imputaciones demasiado exageradas", afirmó que "los señores concejales se pusieron truculentos, especialmente los del PSC. No hay ninguna carga tremenda, ni insoportable, ni va a resultar más caro que vivir en París, son exageraciones sumamente grandes" (85).

Aseveró que se trataba más bien de una racionalización del sistema tributario que se estaba convirtiendo en inmanejable, ya había cumplido un ciclo y requería remozarse. Nuevamente explicó detalladamente los distintos componentes tributarios del proyecto, respondió pormenorizadamente las inquietudes de los concejales, concluyó exponiendo el concepto de fondo:

Yo quisiera que se piense en algo mucho más amplio, modernamente los autores, los tributaristas, los científicos de las finanzas públicas, hablan de que la necesidad del financiamiento en las áreas municipales se haga con base en la contribución especial o de mejora, que resulta ser más justa la contribución, en donde se participa para financiar la obra que le está beneficiando directamente, esto puede tener una variación pequeña, cuando hay ciertas obras generales de la ciudad que benefician indiscriminadamente a todas las propiedades, por ejemplo, un mejoramiento del ingreso sur de la ciudad beneficia a toda la ciudad, enriquece a los predios. (90) 
El director de Planificación, Fernando Carrión, explicó que en el cantón Quito se vive una "crisis de gobernabilidad", derivada no solo del tamaño de su población, sino de su complejidad y de la cantidad de instituciones públicas y privadas interviniendo en un mismo tema, lo que provoca caos en su administración. Las crecientes demandas de equipamiento, de servicios, infraestructura y demás que se observan en la ciudad, frente a una oferta limitada del mismo municipio y en general del Estado ecuatoriano, han conducido a ese problema caracterizado como de crisis de gobernabilidad (93). A su juicio, un asunto a considerar es el siguiente:

un proceso de urbanización absolutamente concentrador y excluyente que ha conducido justamente a que la ciudad de Quito se convierta en el receptor final de migraciones de población, de capital, de recursos, etc. que se ve que generan una serie de desequilibrios regionales no solo en la ciudad, sino en el conjunto del país y de la provincia. (93)

Explicó que el propósito de fondo es que el Concejo Metropolitano sea un concejo para la ejecución del plan integral de desarrollo metropolitano, pues la LRM no conduce a una propuesta de desarrollo de la ciudad, por lo que se plantea la posibilidad de que el distrito metropolitano sea un ente estatal "de desarrollo", y no exclusivamente "de tipo físico como se establece en la normativa municipal". En el proyecto se fortalece al alcalde y al Concejo Metropolitano que tiene la capacidad de fijar los límites urbanos y establecer las zonas metropolitanas, y reiteró que debido a la gran dinámica del proceso urbano no tenía sentido ajustarle a una ley (94-6). En definitiva, dijo que se busca fortalecer el gobierno local con la ampliación de sus competencias y el incremento de sus ingresos.

Finalmente, el alcalde reconoció que el diálogo con los concejales fue positivo, ratificó que todos comparten el interés en hacer el distrito metropolitano, se aclararon los conceptos y se incorporarán los aportes en el proyecto de ley, remarcó la buena intención de la propuesta y pidió celeridad en su aprobación. Convocó a la siguiente sesión del Cabildo Municipal para su anuencia final. 
En las exposiciones y debates en el Cabildo Municipal sobre el proyecto de distrito metropolitano de Quito, si bien hubo múltiples aspectos teóricos y metodológicos que se expresaron en su caracterización como estructura de gobierno local, me referiré, brevemente, a cuatro elementos que considero configuraron la matriz simbólica cultural con que empezó el distrito metropolitano, que, consciente o inconscientemente, fue compartida por las autoridades locales y son los siguientes: la naturalización de la ciudad, el predominio de lo urbano como el vector de la modernidad, la ampliación de la idea de ciudad hacia una región y la tributación como condición autónoma de lo público metropolitano.

De las intervenciones de las autoridades locales y los asesores externos se desprende que la ciudad fue asumida como un hecho dado, tomada como una condición material previa a la propuesta de distrito metropolitano: la ciudad ya estaba ahí. No hubo referencias explícitas al poder dentro de la ciudad, a su historia reciente de conformación; las intervenciones dieron por sentada su existencia, como un piso común desde el cual se enunciaron los discursos propositivos y críticos. La ciudad aséptica aunque desordenada, carente del espacio en el que se configuran las relaciones de poder, se mostraba como un evento inmanente al territorio, si bien hubo explicaciones de los desequilibrios regionales, la pobreza, la desigualdad social, el urbanismo desbordado y concentrador, todas se formularon como tendencias propias del crecimiento urbano.

Asimismo, las observaciones a la reforma política en curso, a la merma de atribuciones del concejo, al fortalecimiento del ejecutivo municipal, al rol de los directores zonales y a los derechos de los vecinos, se plantearon como críticas desde y hacia el sistema de representación político. En las intervenciones no hubo referencias al patrón del poder regional con el que se configuró el espacio de la ciudad capital, paradójicamente, cuando el escenario del debate era precisamente la instancia representativa del gobierno local.

La manera en que el burgomaestre planteó el proyecto de distrito metropolitano, racionalizada por sus asesores, se basó en la constatación de una ciudad con problemas de servicios, infraestructura y limitaciones institucionales que impedían controlar su crecimiento, había que 
renovarlos con un enfoque administrativo moderno, como en las demás capitales del mundo. La idea de la "administración metropolitana” se convirtió en el centro de la consideración del cabildo, la que formulada desde una postura de consenso, dejó el espacio necesario para que las críticas y observaciones fueran a su implementación, a volver eficiente la administración metropolitana.

No hubo margen para entender las relaciones de poder que se dan dentro de las ciudades modernas a las que se buscaba emular, ni para comprender que con el distrito metropolitano se estaba encuadrando el acceso a cierto tipo de recursos en la ciudad, con los cuales se ejerce el dominio, consentido discursivamente, en una sociedad de clases, como lo dio a entender el concejal Quintero en su alegato. Aunque no se dijo, la propuesta de conversión del cantón en distrito metropolitano estaba articulada con la creciente transformación capitalista de la sociedad ecuatoriana, por lo que la ciudad a la que se quería ordenar su crecimiento no era la continuidad de un pasado geográficamente extendido, sino la consolidación de una nueva ciudad que había surgido en las últimas décadas: la ciudad de la modernidad metropolitana.

De ahí que en el enfoque metropolitano se destacaba la preeminencia de lo urbano como ordenador del espacio, el territorio, los recursos, la economía y en general de la vida en la ciudad. Lo urbano se asumió como consustancial a lo metropolitano, aludía al complejo de rutinas espaciales cambiantes, no estáticas, que moldeaban a la sociedad y la cultura local. No hubo margen para dudas o réplicas, pues en sus intervenciones el alcalde, las autoridades y los asesores insistieron en el carácter urbano del distrito metropolitano.

Y es que lo urbano quiteño no solo se ha beneficiado por su condición de sede del Gobierno nacional, sino por la relación heterónoma de los poderes regionales con el Estado, con lo que el municipio quiteño en distintos momentos asumió, por delegación nacional, competencias descentralizadas de gestión territorial para la provisión de servicios urbanos, sin que hubiera leyes de descentralización; tendencia que se consolidaría con la asunción de distrito metropolitano, en un nuevo momento de la modernidad marcado por lo urbano, en el que el contraste 
entre el campo y la ciudad debía gradualmente deshacerse mediante el desarrollo urbanístico.

El distrito metropolitano requería despojarse de los territorios rurales, especialmente de los que no estaban considerados en la planificación urbana de mediano y largo plazos. Se descartaba cualquier dicotómica coexistencia urbano-rural, que no fueran aquellas zonas de conservación ambiental, o las rurales residuales en perspectiva de absorción urbanística. No se admitía la avenencia de lo rural, sus fronteras estaban condenadas a difuminarse con el desarrollo urbanístico, por lo que lo rural devino descartable, como efectivamente ocurrió con el desprendimiento de las parroquias rurales al noroccidente del cantón Quito, que se vieron repentinamente involucradas en una cantonización sin mayores elementos unificadores.

Los originarios tres recintos San Miguel de los Bancos, Pedro Vicente Maldonado y Puerto Quito convertidos en parroquias rurales del cantón Quito, creados como parte de la ruta de penetración de la colonización a la zona subtropical del noroccidente de Pichincha, durante la segunda reforma agraria en los años 70, se vieron abocados a asumir las cantonizaciones legadas "desde arriba", emprendiendo desde entonces su propio proceso de integración cultural, espacial e institucional.

En los debates públicos es igualmente importante lo que se dice y lo que no se dice, especialmente aquello que se omite en una suerte de coincidencia idiosincrática. Las autoridades reconocieron que la ciudad creció por ser el destino de las migraciones rurales, no solo de los entornos territoriales inmediatos, sino de lugares distantes ubicados en el radio de mayor influencia regional, los migrantes a la capital provenían, principalmente, de las provincias de la Sierra centro norte del país. En los debates del Cabildo Municipal se aludió a la migración para referirse a las presiones en el uso del suelo urbano, pero no se dijo nada acerca de las crecientes olas migratorias de mestizos rurales, campesinos, indígenas y afrodescendientes que poblaron la ciudad. No se aludió a quienes se asentaron en el tugurizado y deteriorado Centro Histórico, a quienes se ubicaron en los bordes espaciales del mercado inmobiliario forman- 
do los barrios periféricos, en los que se alojaba un tercio de la población capitalina modificando el paisaje y dinamizando su vida.

La aludida urbe metropolitana no era la ciudad cosmopolita receptora de la diversidad cultural; al contrario, era el lugar para ocultar la diferencia cultural de origen rural. Los migrantes afuereños eran encasillados por los mestizos capitalinos, discriminados por extraños, inferiorizados por pobres y racializados por su origen étnico. En ausencia de políticas municipales sociales, del reconocimiento público de la diversidad cultural de los habitantes de la ciudad, la aséptica idea de lo metropolitano como receptora de migraciones conllevaba también un neocolonialismo de las jerarquías sociales y el orden urbano. Ninguna de las intervenciones con las que se debatió el proyecto metropolitano se refirió a los otros habitantes de la ciudad venidos de mundos rurales y periféricos, lo cual corroboraba la preeminencia de lo urbano en la configuración de lo metropolitano.

Concomitante a la geografía del poder regional, el proyecto de distrito metropolitano validó una visión de la ciudad-región, esto es que la capital del país se había convertido en algo más que la ciudad compacta y sus zonas periurbanas. En todas las intervenciones, las autoridades del Cabildo Municipal hicieron suya la frase "Quito y su área de influencia”, con la que se referían flexiblemente a los distintos dominios presentes en la ciudad, a las crecientes jurisdicciones que había alcanzado el municipio capitalino, y a las proyecciones futuras de influjo territorial.

La expresión "Quito y su área de influencia” tenía varios alcances: la ciudad compacta y su zona suburbana, al área metropolitana conformada en los últimos años, el cantón Quito con las parroquias urbanas y rurales, Quito y su microrregión, la ciudad y los cantones vecinos. El término usado en las alocuciones de los asesores se refería a la escala de los factores de uso del suelo, a la demanda de servicios básicos, a la trama vial y las condiciones de movilidad, a la expansión del mercado inmobiliario y la renta del suelo, a la conservación ambiental, a la tributación, a la planificación urbana y la política urbana. Aludía, en una perspectiva sistémica, a las presiones externas ejercidas desde el área de 
influencia sobre la ciudad capital, y a las respuestas institucionales de la ciudad hacia el entorno urbano.

El término traslucía la convicción de que las autoridades locales asumían que la ciudad se encontraba en medio de una región, su crecimiento urbano había visibilizado unos nexos espaciales de mayor repercusión, los que se entroncaban en la dinámica centrípeta de la economía regional. Del punto de vista administrativo el proyecto de distrito metropolitano, al ampliar las atribuciones y competencias municipales, abría paso a la consolidación urbanística del área nuclear de un territorio mayor que históricamente se había configurado en el centro norte del país. Aunque ese no fue un tema explícito en el debate del cabildo, la idea de región estaba implícita en el proyecto metropolitano.

Finalmente, la detallada argumentación sobre la necesaria reforma tributaria propuesta para el distrito metropolitano, así como las igualmente acuciosas réplicas de los concejales sobre los eventuales encarecimientos de la vida en la ciudad, más allá del acuerdo generalizado de fortalecer las finanzas municipales, traslucían un hecho sustantivo: el carácter de la esfera pública metropolitana. Tras las expresiones del alcalde de "sin dinero no hay obras", estaba el pragmatismo de conseguir resultados materiales condicionados por el financiamiento, y también una visión liberal de lo público basado en el tributo, en los impuestos; lo público se refiere al interés de todos los ciudadanos, es público aquello que se hace con el tributo de las personas, por lo que los bienes y servicios públicos son de la ciudad, porque son financiados con los impuestos que pagan sus habitantes.

En el debate sobre la reforma tributaria se evidenció la resistencia al pago de impuestos de los concejales del PSC, tras lo cual estaba la postura de restringir la provisión de bienes y servicios públicos, y ampliar su suministro desde el mercado y el sector privado, buscaban encoger lo público y agrandar lo privado. En cambio, la postura del alcalde de impulsar la reforma tributaria para fortalecer las finanzas municipales y disminuir la dependencia de las transferencias fiscales buscaba robustecer la autonomía municipal, considerando las transferencias intergubernamentales conjuntamente con la apertura a que el mercado y el sector privado compitieran con el municipio en la prestación de servicios. 
La propuesta de reforma tributaria del distrito metropolitano contenía una visión de lo público condicionada por la capacidad impositiva local, apuntalada con el concepto de "pago por mejoras", así, a más de los impuestos a la propiedad, el consumo y los servicios, se grabarían todas las obras macro de la ciudad, con lo que se ampliaba el margen tributario, en condiciones de competitividad en la provisión de bienes y servicios urbanos. Era una ampliación de la esfera pública en la que cabían las alianzas públicas-privadas para la gestión metropolitana.

Así, el proyecto de distrito metropolitano aprobado por el Cabildo Municipal, a más de ser el dispositivo de administración moderna que conduciría a la conversión del cantón en distrito metropolitano, encuadraba la gestión municipal en el marco de una ciudad de existencia incuestionable fruto del crecimiento urbano desordenado, cuya única posibilidad era abrirse al progreso, por medio del desarrollo urbano ordenador del espacio y la vida social. La nueva ciudad-región se mostraba provista de una esfera pública estatal y no estatal, al mismo tiempo intervencionista y de mercado.

El consenso logrado entre las autoridades locales en el proyecto de DMQ, planteado como el conector cultural que conduciría a consolidar la expansión moderna de la ciudad, fue la consecuencia de un acto hegemónico del alcalde y las élites del gobierno local y la ciudad, por el que la adopción del estatus metropolitano, en emulación a las grandes capitales occidentales, era impostergable.

\section{El horizonte detrás de la normativa}

La LRDMQ, aprobada por el Cabildo Metropolitano, fue presentada al presidente de la República y luego al Congreso Nacional, en julio de 1990. Tardó tres años en su consideración, pues por distintas razones no se trató en la Comisión de Régimen Seccional y luego en el pleno legislativo, hasta que se aprobó el 11 de noviembre de 1993 y se publicó en el Registro Oficial 345, del 27 de diciembre de 1993, con lo que entró en vigencia (LRDMQ 1996).

En un texto compacto la ley recogía el espíritu general de lo propuesto por el exalcalde Rodrigo Paz, en la que se destacaba, en palabras 
del alcalde Jamil Mahuad: "su flexibilidad, que le permite adaptarse a las cambiantes condiciones a las que debe enfrentarse una ciudad como Quito, y su capacidad para convertirse en instrumento eficiente para descentralizar funciones y conseguir que la administración municipal esté cada vez más cerca del ciudadano y sus problemas" (5). Le correspondió al alcalde Mahuad, electo por la misma DP, iniciar la transición al distrito metropolitano.

La ley se aplicó de modo exclusivo al cantón Quito que pasó a denominarse Distrito Metropolitano de Quito. Se formuló de modo consistente con la normativa de la LRM, amplió algunas facultades y competencias exclusivas para el municipio en el Distrito Metropolitano, resultado de lo cual la gestión metropolitana se amparaba en dos normas del régimen seccional. Quince años más tarde, con la Constitución de 2008 que estableció a los distritos metropolitanos como nivel de gobierno especial, se integraron ambas normativas en el Código Orgánico de Ordenamiento Territorial, Autonomías y Descentralización (COOTAD) de 2010.

La LRDMQ, en su orientación estratégica, estaba alineada con la Ley de Modernización del Estado, privatizaciones y prestación de servicios públicos por parte de la iniciativa privada, expedida en 1993, con la que se profundizó la reforma neoliberal del Estado. En la versión ecuatoriana, la privatización estatal se orientaba a incrementar la entrega de recursos públicos al sector privado, trasladando capital antes que activos, estos últimos solo en casos excepcionales a empresas internacionales, y una descentralización nominal que se limitó a ampliar la transferencia de recursos públicos a los gobiernos seccionales que pasó del $8 \%$ al $21 \%$ del presupuesto del Estado, en la década de los 90. Con la adopción de la LRDMQ, el cantón Quito fue el único caso de un gobierno local que acentuó la iniciativa privada y la empresarización de los servicios públicos municipales.

La norma amplió el radio de competencia del municipio capitalino a áreas con exclusividad regulatoria (suelo urbano, tránsito y transporte, medioambiente, participación comunitaria, entre las principales) en las que la única autoridad competente era el municipio metropoli- 
tano. La finalidad declarada en la ley, a más de las establecidas para los municipios en la normativa municipal, era que: "Regulará el uso y la adecuada ocupación del suelo y ejercerá control sobre el mismo con competencias exclusivas y privativas. De igual manera regulará y controlará, con competencia exclusiva y privativa las construcciones o edificaciones, su estado, utilización y condiciones" (14).

Para el ejercicio del gobierno metropolitano en condiciones de desconcentración administrativa y de servicios, así como para asegurar la participación de sus habitantes, se dividió el territorio distrital en zonas metropolitanas, las que estaban dentro del límite urbano se denominaron zonas metropolitanas centrales, y las que estaban fuera de límite urbano zonas metropolitanas suburbanas. El Concejo Metropolitano mediante ordenanza establecería las zonas según el plan de desarrollo distrital, pudiendo fusionarlas, ampliarlas o eliminarlas, para lo cual, en principio, regló que las zonas corresponderían a una o más parroquias metropolitanas (16).

El gobierno del distrito se ejerce por el Concejo o Cabildo Metropolitano integrado por concejales o ediles y por el alcalde metropolitano, quien dirige la administración en calidad de la más alta autoridad. Se ratificó la supremacía del alcalde con facultades no transferibles por su condición inherente de presidente del Concejo Metropolitano, así como en su calidad de jefe de la Administración Distrital, conforme a las atribuciones de la ley y de la normativa municipal, pudiendo delegar facultades y atribuciones al administrador general, los administradores zonales y directores generales subordinados a su mando. Cuestión que se ratificaba con el enfoque de desconcentración del ejercicio de funciones de la administración distrital, para el "logro de niveles más altos de eficiencia".

La ley enfocó la acción municipal en el ámbito urbano del Distrito Metropolitano, si bien como municipio del cantón tenía jurisdicción y autoridad sobre las parroquias rurales, se fortalecían sus capacidades de competencia para la gestión urbana de la ciudad. El municipio quiteño, en años anteriores y por iniciativa de sus alcaldes, había asumido algunas competencias descentralizadas en coordinación con el Gobierno nacional (la dotación del servicio de energía eléctrica, salud pública 
y educación primaria y secundaria, entre otras); con la ley, se transferían las competencias de tránsito y transporte, medioambiente y participación. Sobre esta última estableció como finalidad que

Propiciará la integración y participación de la comunidad. Las Ordenanzas establecerán mecanismos para que la comunidad participe, no solamente en el financiamiento de los proyectos destinados a satisfacer sus necesidades, sino también en la identificación de tales necesidades, en la planificación de los proyectos, en su ejecución y en el mantenimiento de las obras o servicios. (15)

El enfoque de participación mostraba el interés por el involucramiento de la comunidad en los procesos de gestión metropolitanos, pero tenía un doble sentido. Por un lado, buscaba con la participación que la gente contribuyera en la identificación de problemas y soluciones a los problemas cotidianos de la ciudad, al menos en su órbita de acción inmediata en los barrios periféricos y las parroquias rurales; mientras el área nuclear de la ciudad era atendida con la inversión privada y pública. Por otro lado, promovía que la gente movilizara sus propios recursos para la operación y mantenimiento de las obras y servicios públicos, en calidad de usuarios comprometidos con su funcionamiento; era un resabio de la participación con enfoque de demanda, promovida por la cooperación multilateral para la gestión de servicios en los sectores de bajos ingresos.

A pesar de la ambigüedad de las definiciones neoliberales, la propuesta de participación, al menos en el enfoque de la ley, era de involucrar a la comunidad en calidad de beneficiaria en el ciclo de los proyectos públicos, cuestión que se mostraba como una propuesta de avanzada, porque la posterior Ley de Participación Social y Descentralización de 1996 no consideró la integralidad del proceso participativo. Recién en la Constitución de 2008, con el complejo de normas e instituciones de participación ciudadana, se asumió el enfoque de participación ciudadana en el ciclo de las políticas públicas.

Asimismo, la ley blindó la autonomía del municipio metropolitano. Fortaleció la capacidad legislativa del Concejo Metropolitano, facultándole emitir ordenanzas relativas al "desarrollo integral y la ordenación 
urbanística del Distrito", a la prestación de servicios públicos, la promoción cultural y demás materias de competencia municipal. En adelante, le correspondería al municipio la aprobación de los planes de desarrollo metropolitano, las normas para uso y aprovechamiento del suelo, prevención y control de la contaminación ambiental; normar la tributación municipal; reglamentar el uso de bienes de dominio público, el transporte público y privado, el uso de vías y la circulación de todo tipo.

Amplió las potestades para contratación de empréstitos internos y externos para la fijación del límite urbano, la gestión de las zonas metropolitanas y sus parroquias, de establecer las políticas de acción institucional, la privatización y empresarización de los servicios públicos (18-21). Sobre esto último, el art. 8 en el numeral 12 decía abiertamente: "Resolver sobre la constitución de empresas públicas, la concesión de servicios públicos al sector privado y la participación en otras empresas con el capital privado para la prestación de servicios, la ejecución y mantenimiento de obras y, en general, para las actividades económicas susceptibles de ejecutarse empresarialmente" (20).

Literalmente se daba paso a la empresarización de los bienes y servicios municipales, en el sentido de incorporar el enfoque empresarial en la gestión de los servicios públicos, más que transferir o vender al sector privado la infraestructura pública, se trataba de incorporar los procedimientos de la gerencia moderna en la prestación de los servicios públicos, con lo que la agenda privatizadora y empresarial completaría el proceso de copamiento del enfoque privado en la acción pública metropolitana. No era un simple traspaso de dominio, sino la adopción de la cultura empresarial que configuraría la acción pública local.

La ley se encargó de ratificar el enfoque y la prioridad en el desarrollo urbano del DMQ, no dejó flancos descuidados ni posibles filtraciones. Dentro del régimen de mancomunidad urbana, estableció convenios en lo relativo al ordenamiento urbano, la conservación del ecosistema y la prestación de servicios, dentro el distrito y en los municipios circunvecinos. Tendría el mismo efecto jurídico que una ordenanza y se aplicaría en los ámbitos de la planeación urbana, regulación del suelo, control y fomento del desarrollo urbano, prestación de ser- 
vicios y todo lo relacionado con el uso del suelo, aun cuando no esté dentro del límite urbano (31-2).

En las disposiciones generales se corroboró ese enfoque, con la competencia exclusiva que remarcaba la decisión sobre el destino del uso del suelo y su forma de aprovechamiento dentro del territorio distrital que le compete, exclusivamente, a las autoridades del Distrito Metropolitano. Señaló que ninguna institución pública podrá construir edificaciones o infraestructura para servicios públicos sin la autorización municipal. Y en las disposiciones transitorias incorporó a las empresas municipales, que se habían formado con anterioridad, a la nueva administración del DMQ.

Así, el horizonte institucional que se perfiló en la LRDMQ se desprende de su carácter flexible y adaptable a los cambios, cualidad que se muestra como su fortaleza. El principio jurídico de no colocar lo sustantivo de las atribuciones metropolitanas en la ley, sino que sea mediante ordenanzas municipales que se actualicen, una cuestión largamente argumentada en el cabildo, se asumió por entero en la ley.

Se presentó como un recurso adecuado a contextos cambiantes que requieren adaptaciones institucionales, pero las adecuaciones no son fortuitas ni azarosas, sino que llevan por un derrotero intencionado y gobernado por un propósito deseado. En general el espíritu de la ley es congelar las atribuciones y competencias, aunque su actualización implica engorrosos y demorados procedimientos legislativos, preserva una función regulatoria que ampara las virtudes de la intervención pública; en cambio, con una ley compacta como la que se aprobó, se facultó la emisión de un continuo y abultado corpus de ordenanzas metropolitanas conforme a las modificaciones del contexto, con lo que la gestión municipal entró en el cauce de la discrecionalidad de las decisiones y uso de los recursos públicos.

La flexibilidad de la LRDMQ esboza una práctica de desregulación de lo público, en boga en los años de influencia neoliberal. Bajo su cobijo, en el transcurso de las siguientes décadas ocurrió una perenne adaptación normativa, justificada por los cambios de la estructura urbanística de la ciudad, por la adecuación funcional de sus distintos 
componentes urbanos y suburbanos, y por la creciente integración territorial proveyendo infraestructura básica, servicios, equipamiento y vialidad. La lógica de la flexibilidad de la ley es facultar que la normativa municipal responda a la evolución metropolitana, según los flujos de los capitales y los impulsos del mercado.

En consonancia, se impulsaron sucesivos "proyectos de ciudad acordes a las nuevas realidades y a las necesidades futuras" (PUOS 2003, 14), sobre un territorio que demanda control, pues la inversión inmobiliaria solo puede hacerse en el $7 \%$ de la superficie cantonal que presenta las mejores condiciones de uso urbano, el resto es suelo no urbanizable debido a su geografía y ecosistemas. La ciudad ejerce una enorme presión sobre la porción del suelo urbanizable del distrito metropolitano, su expansión en las últimas década copó casi toda la extensión de la meseta de Quito y se desbordó hacia los valles orientales, configurando una ciudad denominada por unos "archipiélago", y por otros como "dispersa o policéntrica”. Más allá de la denominación, la forma actual de la ciudad muestra una tendencia de crecimiento urbano desordenado, siguiendo la lógica de los negocios del complejo financiero inmobiliario quiteño, acostumbrado al capitalismo rentista, como puede verse en el mapa 1.

En el centro del modelo organizativo implícito en la LRDMQ está un dispositivo vertical de toma de decisiones que privilegia la jerarquía en el ordenamiento institucional, y las negociaciones entre las autoridades locales y los decisores políticos del juego del poder en el escenario metropolitano. Apuntala un modelo de "decisores activos" que actúan de modo inmediato en las políticas metropolitanas y en el control corporativo de la gestión urbana, por medio de un andamiaje institucional que eslabona la desconcentración de funciones, la descentralización de competencias y la participación de la comunidad, siguiendo orientaciones afines con la "nueva administración pública". 


\section{Mapa 1}

La forma dispersa de la ciudad

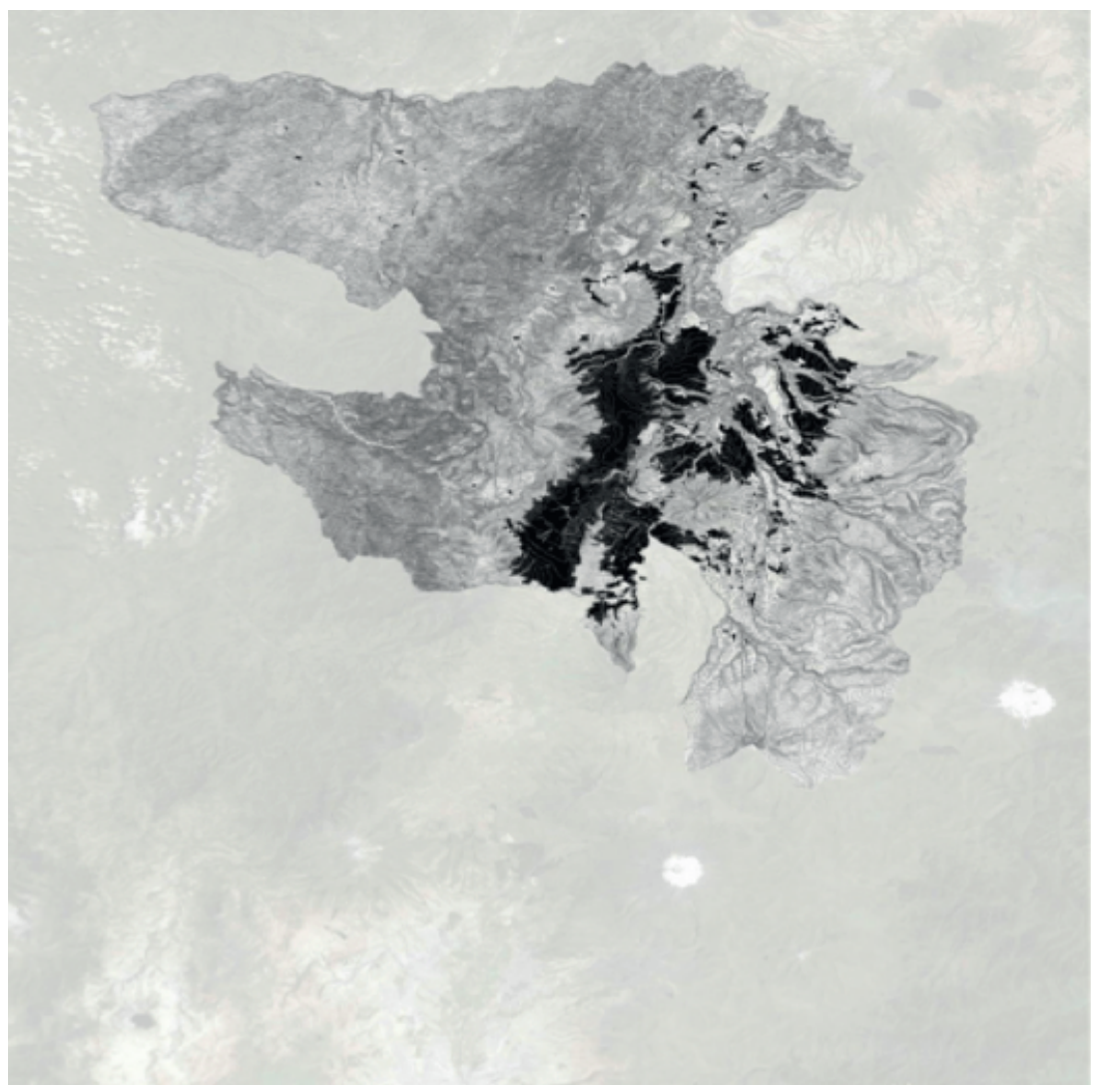

Fuente: MDMQ, 2012, Diagnóstico Estratégico-Eje Territorial.

Por mandato de la ley se fortalecieron las atribuciones del alcalde metropolitano, y se robusteció la estructura ejecutiva de la Administración Metropolitana. Validó el ejercicio decisional del círculo inmediato del alcalde, generalmente externo al municipio, facultándole compartir con el "nivel jerárquico superior" de la entidad la responsabilidad técnica y política de las decisiones. El esquema de la organización metropolitana se asemeja al enfoque del "juego del poder", esto es las complejas interconexio- 
nes entre la autoridad y los diversos tipos de decisores de políticas públicas, los partidos y los grupos de interés (Lindblom 1991, 57), en la ciudad.

El juego del poder reconoce el papel de las élites de decisoras, en el marco de interacciones políticas intensamente reguladas por normas morales, que establecen los roles que ha de cumplir cada uno en la jerarquía institucional, desde las jefaturas arriba hasta los ciudadanos en el otro extremo. Las normas establecen quiénes pueden ser los actores, así como también especifican lo que les es permitido o prohibido hacer en el desempeño de su papel (60). Las normas se cumplen, se obedecen, por diversas razones, especialmente porque son legítimas, no requieren de coerción, ni su aplicación es forzada, sino que se basan en consensos, son concreciones de la hegemonía cultural.

Así, el espíritu de la LRDMQ entroncó tres ámbitos: la sociedad, el municipio y la autoridad. La sociedad quiteña, en la medida en que está organizada en un patrón social que sigue un orden jerárquico, de linaje colonial, por el que se establecen las relaciones de las personas, los grupos y las clase sociales con el poder, fija los rangos dentro de los cuales puede darse la movilidad social, cuando esta ocurre por fuera de lo establecido y altera el orden, sus agentes son removidos (como más adelante, en la última sección del cuarto capítulo, podrá verse).

El municipio metropolitano, a su vez, se asume como un modelo organizativo igualmente jerárquico, con rangos de responsabilidades definidas e infranqueables. Se distinguen los niveles superiores donde moran, en exclusividad, las decisiones de las élites políticas y gerenciales; de los niveles intermedios de acción estratégica como planificación, coordinación territorial, tributación, obras, entre otras; y los niveles inferiores con funciones operativas y administrativas para la prestación de bienes y servicios metropolitanos (según se muestra en la primera sección del segundo capítulo).

La autoridad se ejerce en símil con la hegemonía. Se genera en la cúspide del sistema y se despliega en sentido descendiente, afectando, contaminando, a los demás estamentos de la institucionalidad metropolitana, hasta provocar consecuencias en la ciudadanía. La autoridad se despliega con la persuasión a la ciudadanía de una promesa de bienestar 
en el distrito metropolitano, apoyándose en el manejo mediático de los mensajes y símbolos gubernamentales en conexión con el poder local.

En suma, la normativa metropolitana formulada por el Cabildo Municipal no era ajena a los valores y costumbres cívicas de la sociedad local, ni extraña a la jerárquica cultura política quiteña, por el contrario, en una cohesión de aspectos normativos, institucionales y de autoridad, alegó su potencialidad para una efectiva modernización municipal, funcional con la conversión del distrito metropolitano, al tiempo que se mostró conservadora en sus alcances estratégicos, porque su orientación era la de institucionalizar las prácticas heterónomas de las élites gobernantes de la ciudad-región frente al Estado-nación.

La ley metropolitana, desde su concepción y en su aplicación, devino en una macropolítica municipal que en adelante encuadrará las políticas metropolitanas, la planificación urbana, la programación municipal, el manejo del distrito y en general todos los dispositivos público-privados del desarrollo urbano. En la trayectoria de la ciudad-región hacia la urbe competitiva, núcleo de la economía regional y cultora de las libertades individuales que promueven el progreso, la adopción de la norma metropolitana estableció el umbral simbólico de no retorno en la ruta modernizadora quiteña.

En suma, la expansión metropolitana de la ciudad estuvo articulada a la funcionalidad regional, en la medida en que respondió a los impulsos de conversión de los propietarios de haciendas, fincas, quintas y terrenos baldíos en ciudadelas, urbanizaciones, lotizaciones, programas estatales y mutuales de vivienda, y áreas de expansión urbana donde ocurrieron las desordenadas implantaciones industriales, comerciales y residenciales. La concentración de capitales del complejo inmobiliario, financiero y comercial de los grupos económicos quiteños estuvo detrás del desorden territorial provocado con la expansión metropolitana desde la segunda mitad del siglo XX. El municipio capitalino, secularmente vinculado a los intereses de los grupos económicos quiteños, supo aprovechar su cercanía a los poderes regionales en la implementación de las políticas urbanas con la expansión metropolitana. 
El simbolismo de las autoridades locales en la adopción del régimen metropolitano a comienzos de los años 90 mostró el carácter jerárquico y elitista de una decisión pública tomada en las altas esferas privadas y empresariales, con enorme implicación en la vida de la ciudad, en la que los valores prescriptivos de parecerse a las grandes metrópolis modernas marcarían el derrotero metropolitano de las siguientes décadas.

Desoyendo cualquier otra propuesta, la decisión de las autoridades se materializó en una compacta normativa que asertivamente ratificó al distrito metropolitano en correspondencia con el cantón Quito, definió a lo metropolitano como lo urbano y a lo rural, aunque necesario, como algo descartable; blindó la autonomía municipal, amplió las atribuciones del burgomaestre a costa de los concejales, y facultó un complejo institucional presidido por una función ejecutiva desconcentrada en administraciones zonales y descentralizada en empresas y corporaciones municipales de servicios públicos. El municipio capitalino entró en una fase de conversión a distrito metropolitano, con la consecuente readecuación institucional, cuestión que analizaremos en el siguiente capítulo. 


\section{Capítulo II \\ LA SEMÁNTICA \\ DE LA EXPANSIÓN METROPOLITANA}

Las narraciones culturales contenidas en los dispositivos de acción pública, como los planes urbanos, más allá de su influencia en las políticas metropolitanas, develaron las promesas de orden urbano y progreso material para la ciudad. A manera de relatos públicos de futuros imaginados, o al menos deseados, evidenciaron la disponibilidad de las autoridades locales para programar el crecimiento de la urbe y ampliar la dotación de infraestructura, equipamiento, bienes y servicios básicos, al mismo tiempo que apostaban por la regularización urbana del desorden territorial. Quito se precia de una trayectoria de planificación en la que, sucesivamente, se fue ensamblando una perspectiva cada vez más asertiva de la ciudad-región, que es heredera de una secular relación heterónoma con el Estado-nación, permitiéndole mantener una continua readecuación municipal conforme al crecimiento de la ciudad, y que se consolidó con la conversión en distrito metropolitano.

El segundo capítulo se enfoca precisamente en las narrativas culturales de la planificación quiteña, especialmente de la metropolitana entroncada con la readecuación municipal. Se explican las transformaciones y continuidades de la estructura organizacional del municipio en el proceso metropolitano capitalino, destacando el simbolismo de la modernidad urbana del arreglo institucional adoptado, el que trata los asuntos públicos de la ciudad con una inclinación hacia lo privado. El capítulo está dividido en tres secciones: la primera explica la conversión experimentada por el municipio capitalino que derivó en un híbrido de Estado y empresa pública; la segunda interpreta los relatos culturales de progreso y orden urbanos contenidos en los planes metropolitanos; la tercera examina las tendencias de concentración económica y segregación urbanas acentuadas con el proceso metropolitano. 


\section{El municipio metropolitano: Entre Estado y empresa}

La historia de Quito es la historia de los poderes regionales, de la trayectoria del cabildo y sus relaciones con la gente y el espacio urbano. Es la memoria del sometimiento de las diferencias sociales y culturales a las uniformidades de la ciudad, y de la escalonada ocupación de un territorio de pueblos originarios, transformado en haciendas, estancias y poblados, más tarde convertido en ciudadelas, urbanizaciones y barrios. El contraste paisajístico entre el presente y el pasado del territorio metropolitano es dramático.

La radical transformación del paisaje natural y social se originó en la conquista española con la villa trazada en damero por el cabildo, que agrupó a la población indígena en reducciones, convertidas en los primeros barrios de la ciudad. Conforme se expandió la urbe, se incorporó a los poblados de los valles circundantes como parroquias rurales, las que más tarde se convirtieron en zonas metropolitanas. Con la colonización del territorio y la expansión del damero se sometieron a las poblaciones nativas, aunque algunos pueblos conservaron las originarias formas de ocupación territorial; fue la génesis espacial de la modernidad colonial de la ciudad. Con relación al contraste de los cambios en el paisaje de Quito, Jorge Núñez (2017) relata:

El nativo fue alejado de la proximidad del agua, elemento que le era tan familiar y querido, donde estaban sus cultivos de cereales y hortalizas y sus fuentes de proteínas (peces y aves), y encerrado en pueblos artificiales, distantes de sus cultivos y alejados de su modo de vida tradicional. Es más, el español vio todo eso como un esfuerzo moralizador y civilizatorio, por el que los nativos eran alejados de los "montes, ciénagas y barrancos" que habían tenido por hábitat, para ubicarlos en pueblos de "buena habitación y policía", donde podían ser fácilmente cristianizados y controlados por la autoridad colonial. [...] los territorios situados al norte y sur de la villa se convirtieron en ejidos o tierras comunales de la ciudad y la zona ubicada a los lados del río Machángara fue transformada en dehesas o potreros de uso público, siguiendo los mandatos de las Ordenanzas de Poblamiento del rey Felipe II. Más tarde, los ejidos del norte y sur de Quito fueron sometidos a un plan de disecación de sus lagunas y humedales, para aprovecharlos como tierras agrícolas. Fi- 
nalmente, ya en el siglo XVIII, las oligarquías formadas alrededor del cabildo de la ciudad se convirtieron en arrendatarias de estos ejidos, primero, y luego en propietarias de los mismos, que se transformaron en haciendas y estancias. (párr. 2 y 3 )

De lo afirmado por Núñez, se desprende la existencia de un histórico patrón público-privado de ocupación del espacio que transformó la geografía quiteña: familias nobiliarias emparentadas con los conquistadores (1990), mediante las intervenciones del cabildo coparon los mejores lugares, redujeron a las poblaciones, modificaron a su conveniencia el paisaje y se apropiaron del territorio. Es un sometimiento colonial que parecería corresponder a etapas del pasado, sin embargo, mutadas las familias nobiliarias en grupos empresariales, a comienzos del siglo XXI, la ocupación del espacio continúa con la conversión de la ciudad-región. Es el presente de una larga duración de ocupación colonial territorial, cuyo tramo reciente es la evolución a distrito metropolitano.

Del mismo modo que ocurrió un cambio drástico en el paisaje de Quito, sobrevino una transformación sustantiva en el gobierno de la ciudad: el viejo cabildo castellano impuesto con la conquista se convirtió en el moderno municipio metropolitano de la ciudad-región. En la Colonia, tras la fundación de la villa, se formó el cabildo integrado por alcaldes mayores, menores, de hermandades, regidores y una ralea de oficios públicos; tenía una relación contractual de autonomía con la Corona, y estaba vinculado al gobernador, encomenderos y las órdenes religiosas que integraban la Audiencia de Quito. Por mandato real se elegían los alcaldes y regidores entre las familias nobiliares criollas y peninsulares, y el cabildo operaba con deliberaciones y decisiones registradas por escribanos en los libros capitulares; en sus entornos se integró la estructura estamental y nobiliaria del poder local de la aristocracia capitular quiteña (Ponce 1998).

Con la formación de la República, el cabildo continuó con sus principales funciones de higiene, ornato, cuidado. Se suprimió la dignidad de alcalde y el cabildo fue reemplazado por la "corporación municipal”, dotada de autonomía y sujeta a las decisiones del Gobierno nacional. El municipio estaba dirigido por el presidente del Concejo Municipal, in- 
tegrado por ediles electos por votación popular y con capacidad de emitir ordenanzas dentro de la jurisdicción cantonal (Ayala 1991). La primera LRM de 1861 ratificó su autonomía, la facultad de dictar ordenanzas cantonales y regló su institucionalidad como una réplica a escala cantonal del Estado, con un ejecutivo regido por el presidente del Concejo Municipal, y un legislativo integrado por ediles, quienes en su mayoría eran representantes de las familias nobiliarias, hacendados y comerciantes, ratificando la estructura del poder local (Núñez 2003).

A lo largo del siglo XX se sucedieron hasta veinte reformas y numerosas codificaciones a la LRM, las que paulatinamente incorporaron nuevas atribuciones municipales. En el período de implantación del distrito metropolitano, la ley vigente era la de 1966, reformada en 1971 y luego en 1982; establecía como finalidad del municipio el "bienestar de la colectividad", por medio de la "planificación física del cantón y sus áreas urbanas y rurales”, acrecentar el "espíritu de nacionalidad” y progreso, y promover el "desarrollo económico, social, medio ambiental y cultural dentro de su jurisdicción”.

Sus funciones, enmarcadas en los planes nacionales y regionales de desarrollo económico y social que adoptara el Estado, eran proveer de sistemas de agua potable y alcantarillado; construcción, mantenimiento, aseo, embellecimiento y reglamentación del uso de caminos, calles, parques, plazas y demás espacios públicos; recolección, procesamiento o utilización de residuos; planificación, coordinación y ejecución de planes y programas de prevención y atención social; planificación del desarrollo cantonal; regulación del uso de la vía pública en áreas urbanas y suburbanas de las cabeceras cantonales y en las áreas urbanas de las parroquias rurales del cantón; contribuir al fomento de la actividad productiva y su comercialización, mediante programas de apoyo a actividades como la artesanía, microempresarias y productoras de la pequeña industria, etc., en coordinación con organismos nacionales, regionales, provinciales y parroquiales; colaborar y coordinar con la Policía Nacional, la protección, seguridad y convivencia ciudadana (LRM 2005), entre otras.

Tal como el Estado, el municipio estaba organizado por ramas de actividad y con dependencias de obras públicas, justicia y policía, 
financiera, administrativa, higiene, salubridad y ambiente, educación y cultura, servicios sociales, asesoría jurídica, planificación, desarrollo de la colectividad y protección de los grupos vulnerables. El Reglamento Orgánico Municipal establecía tres niveles de funciones: director o toma de decisiones, coordinación y seguimiento; asesor para asistencia técnica y legal en planificación, programación y proyección de actividades, y operativo, para la ejecución de funciones. Además, la ley facultaba la creación de empresas municipales para prestación de servicios públicos, y empresas de economía mixta con directorios mayoritarios del sector privado, con el propósito de "solucionar eficaz y oportunamente los problemas que la ciudad enfrenta” (2005).

\section{La readecuación institucional}

Con la adopción de la LRDMQ, el municipio acentuó la autonomía institucional, la descentralización y empresarización de la prestación de servicios públicos, y formalizó la ciudad-región. Fortaleció las atribuciones del alcalde y del aparato ejecutivo con una gradual readecuación institucional empresarial; y continuaron los concejales con las atribuciones de legislación, fiscalización, formulación y aprobación de políticas, y participación en comisiones y empresas. El concejo proverbialmente integrado por personajes vinculados a los intereses económicos de la ciudad, con la conversión a distrito metropolitano dio paso a la democratización del gobierno local y a la creciente presencia de nuevos políticos, líderes y dirigentes populares.

La mayoría de los alcaldes electos de la ciudad, salvo quizá dos casos, uno de ellos el más reciente, como anotamos anteriormente, provinieron de los círculos económicos y políticos de la ciudad, por lo que fueron personajes acostumbrados al poder, a tomar decisiones en haciendas, empresas, instituciones y negocios privados. De los veintitrés alcaldes quiteños, cinco intentaron pasar del sillón municipal al sitial presidencial del país, pero solo dos lo consiguieron. Rodrigo Paz fue el último empresario que por elección popular asumió la alcaldía de la capital, en adelante y hasta la actualidad los alcaldes capitalinos electos han sido políticos profesionales. 
Igualmente, el Concejo Municipal que estaba integrado principalmente por concejales vinculados a los sectores económicos y nobiliarios de la ciudad, a las maquinarias electorales de los partidos políticos liberal, conservador y velasquista, progresivamente se renovaba con una representación plural de las fuerzas políticas de la ciudad, de la sociedad civil y de los sectores populares. El Concejo Municipal, adoptando la normativa metropolitana, se remozó con ediles provenientes de los nuevos sectores sociales en ascenso, aunque continuaron eligiéndose los notables, caciques barriales y deportivos vinculados con las maquinarias electorales de los también nuevos partidos políticos (ID, DP y PSC) que, a su turno, desde el municipio se dedicaban a reemplazar o funcionalizar las maquinarias electorales barriales de los anteriores partidos políticos, especialmente las del Partido Liberal.

El clientelismo o el cambio de lealtades por servicios públicos está arraigado en la cultura política de la capital, se ejerce por igual entre las autoridades locales como entre los notables, líderes, dirigentes y personalidades de las clases altas, medias y populares. Forma parte de un comportamiento idiosincrático de acceder a los servicios a cambio del apoyo electoral y de asegurar la presencia popular en las movilizaciones y eventos de respaldo a las autoridades locales. La asunción del distrito metropolitano, lejos de erradicarlo, vigorizó el clientelismo por el verticalismo decisional en las relaciones con la ciudadanía, especialmente con los sectores barriales y populares (como se verá en el tercer capítulo).

La democratización del poder local quiteño, o la eufemística autodefinición de el "Ilustre Municipio es la Sociedad Política Autónoma" (IMQ 1992, 181), no implicó necesariamente la ampliación de los espacios de decisiones estratégicas ni la participación ciudadana en las políticas municipales, sino la inclusión minoritaria de la representación popular en el Concejo Municipal, pues las grandes decisiones de la ciudad, como su mentor lo planteó, continúan morando en las altas esferas del alcalde y sus decisores revestidos de atribuciones, y secundados por la mayoría edilicia con agendas particulares alineadas a la modernidad metropolitana.

El municipio quiteño supo acoplar su institucionalidad a la progresiva ocupación territorial, imbricada en la dinámica regional y con 
la gestión de la ciudad, asegurando condiciones materiales de habitabilidad y situaciones providenciales para la economía local. El cometido municipal no era ajeno a los intereses regionales, ni el desarrollo urbano era disfuncional a la región. La compleja gestión municipal de universalizar el acceso a los servicios básicos, transporte, movilidad, seguridad, higiene y la conservación del patrimonial Centro Histórico, es también una manera de certificar la ciudad competitiva y financiera, de impulsar las inversiones inmobiliarias, promoverla como sede de negocios, "polo del desarrollo industrial andino", "centro nacional de servicios turísticos y de transporte de carga por vía área y terrestre", señaló el exalcalde Paco Moncayo $(2007,5)$.

Con el paso del cantón a distrito y del municipio a gobierno metropolitano se asumió el discurso del desarrollo local, que no se refiere solo a promover las iniciativas de economía social y solidaria apoyando emprendimientos de escala o estimulando los circuitos alternativos de las diversas economías populares, sino a la promoción de las grandes inversiones de los grupos económicos afincados en el distrito metropolitano, mediante la regencia estratégica y el control urbano del 7\% del territorio distrital en el que se emplazan la ciudad y la economía regional. Para el municipio capitalino el desarrollo local se definía como

un proceso de crecimiento y cambio estructural de la ciudad que contempla tres dimensiones. Económica: empresarios locales usan eficientemente los factores productivos, aumentan la productividad y mejoran la competitividad en los mercados. Sociocultural: instituciones locales fortalecidas, funcionando en redes, generan relaciones de confianza que sirven de base al desarrollo. Política y administrativamente: las políticas y acciones del gobierno local crean un entorno favorable a la producción e impulsan el desarrollo. (Carrión s. f., 181)

Con la puesta en vigencia de la LRDMQ, el municipio entró en una sostenida reingeniería organizativa que acentuó el carácter empresarial en la prestación de servicios, junto con el robustecimiento de las facultades ejecutivas en símil con el presidencialismo, aunque decadente, de la reforma neoliberal del Estado ecuatoriano. Se puso en marcha un continuo acrecentamiento corporativo iniciado en 1990, implemen- 
tado principalmente a lo largo de las décadas de los años 90 y 2000, durante los períodos de los alcaldes de la DP e ID, ajustado luego por los subsiguientes alcaldes, siguiendo el mismo libreto corporativo y direccionamiento urbanístico.

¿Fueron etapas o un contínuum de readecuación institucional del municipio capitalino? René Vallejo dice que hubo "tres momentos o etapas del proceso de readecuación institucional”. El primero enfocado en las definiciones de la "estructura metropolitana" y la "modernización burocrática”, que comprendió el período del alcalde Rodrigo Paz. El segundo con la conformación del distrito metropolitano, a partir de la puesta en vigencia de la normativa metropolitana, iniciándose la desconcentración empresarial y la configuración del "modelo gerencialista", que abarcó los dos períodos del alcalde Jamil Mahuad. Y el tercero de consolidación del distrito metropolitano como "gobierno local", ampliando la gestión desconcentrada junto con la corporativización de la participación ciudadana, la planificación estratégica, la cooperación público-privada y el desarrollo económico, en los dos períodos del alcalde Paco Moncayo $(2009,77)$.

La idea de etapas supone períodos diferenciados por dinámicas o factores institucionales que cambian o se agotan y que están eslabonadas por fases de transición, eso no sucedió en la readecuación institucional del municipio metropolitano. La idea de momentos parecería adecuada para captar las intensidades de la readecuación institucional, pero al establecer que los momentos corresponden a los períodos de los alcaldes supone que hubo matices administrativos que modificaron la orientación estratégica, cuestión que tampoco ocurrió. La visión de momentos en concordancia a los períodos de los alcaldes más bien muestra la secuencia en la readecuación organizacional, con lo que en realidad se trató de un contínuum expansivo de la institucionalidad municipal, enlazado con la gestión metropolitana. Antes que momentos diferenciados por la reingeniería institucional, fue una escalada modernizadora del municipio capitalino que se explica por tres factores: la alianza política del poder local, la integración de intereses de la economía de Quito y la gobernanza adoptada por los alcaldes. 
La alianza de las tres mayores fuerzas políticas de la ciudad se mantuvo desde el período del alcalde Rodrigo Paz, quien formuló el proyecto de distrito metropolitano, y luego con los subsiguientes alcaldes: Jamil Mahuad que emprendió la transición al distrito metropolitano, y Paco Moncayo que consolidó la estructura institucional metropolitana. En los veinte años de su concepción e implementación, las autoridades locales aseguraron el consenso o la mayoría en las decisiones del Concejo Municipal para las readecuaciones institucionales.

En los dos períodos del alcalde Mahuad, el concejo estuvo integrado mayoritariamente por cinco concejales de la DP, cuatro de la ID y tres socialcristianos. Durante las alcaldías de Moncayo se modificó levemente la representación política del concejo: seis concejales eran de la ID, cuatro de la DP y tres del PSC (MDMQ 2004). La renovación bianual de las minorías en el concejo no modificó la representación paritaria de los tres partidos políticos que, cohesionados, respaldaron a los alcaldes. Y es que las diferencias ideológicas partidarias eran nominales, la DP de su originaria adscripción democratacristiana se convirtió en un remozado partido conservador, la ID de factura socialdemócrata igualmente devino en un renovado liberalismo, y el PSC se mantuvo como una fracción conservadora. Eran las mismas fuerzas políticas de derecha que, alternándose, controlaron el municipio y gobernaron la ciudad capital en los últimos sesenta años.

Los alineamientos de las tiendas políticas capitalinas convergieron en el compromiso con el distrito metropolitano. Los concejales indistintamente de sus filiaciones partidarias, al igual que los alcaldes, hicieron suyo el discurso modernizador metropolitano, y la visión de la "ciudad competitiva" había calado hondo en los ediles convirtiéndose en el horizonte deseado, según se desprende, a guisa de ejemplo, de las palabras del concejal sustituto electo en representación de las fuerzas populares de izquierda que hizo suya la visión elitista empresarial:

me parece que el tema de los negocios se vuelve en fundamental para que la ciudad tenga cada vez más riqueza, no solo riqueza en lo social, riqueza en lo cultural, no solo riqueza en los servicios que se prestan [...] porque eso es lo que queremos, queremos que Quito sea competitivo, 
que Quito atraiga la inversión extranjera, que Quito haga negocios, no el Municipio sino nuestras empresas (MDMQ 2000, 21).

La alianza política que respaldó la adecuación institucional se puso a prueba en distintas coyunturas, especialmente en los eventos críticos de defensa de la capitalidad, cuando el municipio asumió protagonismos reactivos y los alcaldes encabezaron la defensa simbólica ante los excesos presidenciales. Ocurrió en los episodios del alcalde Mahuad contra Bucaram, cuando los concejales cerraron filas en su respaldo; igual sucedió en la defensa de la ciudad contra las huestes gobiernistas de Gutiérrez, cuando los concejales nuevamente respaldaron por unanimidad al alcalde Moncayo. La readecuación institucional metropolitana no era un tema coyuntural, se convirtió en un asunto de la ciudad, así lo asumieron los representantes políticos de la ciudadanía quiteña.

La integración de intereses de la economía de Quito se fortaleció con la asunción del distrito metropolitano. La configuración del territorio mediante las políticas metropolitanas está relacionada con el libre flujo de los capitales regionales quiteños asociados a los transnacionales, en los sectores del mercado interno con la expansión manufacturera, comercial y alimenticia, de los monopólicos emprendimientos inmobiliarios y turísticos, en la alta concentración bancaria y financiera, y del sector exportador con la expansión de la agroexportación florícola y hortícola. Son circuitos económicos que rebasan al distrito metropolitano y a la provincia de Pichincha, pues forman parte de los grupos económicos regionales de alcance nacional (ya explicados).

La racionalidad en la gestión municipal y en las políticas urbanas emprendidas con los alcaldes metropolitanos estuvieron atravesadas por la funcionalidad espacial de la ciudad a la economía regional: vías, servicios, infraestructura, equipamiento, zonas especializadas y aeropuerto facilitaron el desarrollo de la economía de Quito. La readecuación institucional del municipio y la conformación territorial metropolitana fluyeron sin mayores contratiempos, no enfrentaron intereses disruptores, sino que siguieron un estable curso ascendente, paradójicamente en un contexto de recurrente crisis política nacional donde ocurrían los mayores episodios de efervescencia social en Quito. 
El concejo se mantuvo cohesionado, auspiciando la continuidad en las obras emblemáticas metropolitanas que también siguieron el contínuum concepto-implementación-consolidación, como ocurrió con las grandes obras que se implementaron en el transcurso de las distintas alcaldías, conjuntamente con la implantación del distrito metropolitano. Sucedió con el sistema de transporte público diseñado en la alcaldía de Paz, implementado en la de Mahuad y consolidado en la de Moncayo; la misma secuencia interalcaldías, con algunos desplazamientos temporales, siguieron el anillo vial metropolitano, las intervenciones del Centro Histórico, el control ambiental, la expansión urbanística hacia los valles centro-orientales, el aeropuerto de Tababela y recientemente el metro de Quito.

Al final de cada uno de los dos períodos de los alcaldes electos, simbólicamente, emergió la economía detrás de la política, cuando los burgomaestres renunciaron para intervenir en las elecciones presidenciales, siendo sustituidos por concejales de perfil empresarial. Jamil Mahuad fue reemplazado por Roque Sevilla, líder del principal grupo de seguros, turismo y comercial, y Paco Moncayo por Andrés Vallejo, cabeza de otro grupo bancario, comercial e inmobiliario. La sucesión de autoridades no implicó alteraciones de la agenda metropolitana, con lo que la readecuación institucional del municipio estuvo enlazada con la ejecución de las principales obras metropolitanas. No fue una evolución organizacional autorreferida, sino en conexión con la integración de la economía regional entroncada, a su vez, con la modernidad urbana.

La adopción de la gobernanza municipal forma parte de la cultura empresarial y del enfoque de mercado prevaleciente en la gestión metropolitana. La gobernanza, un concepto político influenciado por el debate neoliberal, se refiere a que las políticas públicas son consecuencia de la colaboración compartida entre múltiples actores, y los servicios públicos son resultado de la negociación entre las autoridades locales y los grupos de presión de la ciudad (Vallés 2007). En gobernanza, el municipio se asume como el facilitador entre los intereses públicos y privados para lograr los acuerdos en la prestación de servicios.

Es distinta a la noción de gobernabilidad local que está asociada con el mandato propio del sistema político, procura que los servicios 
públicos sean resultado del complejo legal-burocrático-instrumental urbano, obedeciendo el ciclo de las políticas públicas. La gobernanza, en cambio, está vinculada a la capacidad de autocoordinación propia de las redes locales, constituidas por una "constelación de organizaciones y entidades privadas y públicas, estatales y transestatales” (430), intervinientes en las decisiones públicas.

La gobernanza de los alcaldes metropolitanos implicó la progresiva desconcentración administrativa y la descentralización de servicios, conforme la heterónoma relación del municipio capitalino con el Estado nacional que consiguió se le deleguen, por acuerdo o convenio, la provisión de servicios públicos, sin que hayan mediado normas específicas de descentralización en el país.

Sucedió tempranamente con las concesiones de los caudales de varios ríos para las dos primeras plantas de energía eléctrica del alumbrado público quiteño en 1906, las que se convirtieron en la Empresa Eléctrica Municipal en 1937; con las pioneras escuelas municipales Antonio José de Sucre y Eugenio Espejo en 1915; con la Compañía Municipal de Transporte en 1947, que se convirtió en Empresa Municipal de Transporte en 1980; con la Empresa de Agua Potable en 1960, la Empresa de Alcantarillado en 1963, el Patronato Municipal fundado en 1979, la Empresa Municipal de Rastro en 1983, la Empresa del Centro Histórico en 1984, y el Fondo de Salvamento en 1987 (Vallejo 2009, 86). Las empresas municipales tiene una larga trayectoria en la prestación de servicios en la ciudad.

La readecuación de la institucionalidad metropolitana amplió la práctica empresarial precedente, en la medida en que la creciente transferencia de las competencias para la provisión de servicios públicos a las empresas municipales y la progresiva desconcentración de la administración municipal daban lugar a un holding empresarial metropolitano. La gobernanza implicaba establecer alianzas público-privadas normadas por la rentabilidad de los servicios, así como la creciente potestad decisional del alcalde metropolitano con la desconcentración de la gestión burocrática en las administraciones zonales.

La gobernanza corresponde al modelo organizacional formulado en el espíritu de la ley metropolitana, por lo que la readecuación insti- 
tucional necesariamente tuvo que acoplarse a la cultura empresarial del sector privado quiteño, tradicionalmente vinculado a la gestión de la ciudad, como lo expresó el exalcalde Paz:

Es responsabilidad del Municipio crear la infraestructura necesaria para que esta opción se haga realidad. Lo demás es de competencia de la empresa privada y de otros organismos del Estado. Quiero destacar la cooperación de la empresa privada, que ha sido fundamental en el desarrollo de actividades municipales pues, salvo determinados sectores reacios a todo cambio por pequeño que sea, la mayoría de empresarios ha comprendido y apoyado la gestión municipal. (Gaceta Municipal 1991, 6)

En las dos décadas de implementación del distrito metropolitano, el municipio pasó de una institución centralizada a una compleja institución desconcentrada y descentralizada, con la formación progresiva de las administraciones zonales, el incremento de las empresas metropolitanas y el ensanchamiento de las facultades ejecutivas de las autoridades locales. En ese lapso se operó una transformación organizacional que acentuaba el camino iniciado por las empresas municipales, junto con la nueva presencia territorial de las administraciones zonales.

En el año 1992 el municipio era una organización concentrada, en la que las funciones orbitaban en torno al alcalde que aglutinaba los niveles directivo, asesor y operativo; en la estructura funcional estaban jerarquizadas bajo la línea de mando del alcalde diez direcciones: Administrativa, Avalúos y Catastros, Recursos Humanos, Financiera, Programación, Obras Públicas, Fiscalización, Mercados, Higiene, y Educación y Cultura; y en paralelo, presididas por el burgomaestre, estaban las cinco empresas municipales y las tres dependencias. En conjunto conformaban una estructura administrativa integrada por 8018 empleados: 3070 eran administrativos, 535 docentes, 4195 trabajadores y 218 por contrato, para 1995 el número total de empleados disminuyó a 7148 (MDMQa 1995, 8). Las entidades ejecutoras y operativas gravitaban en un mismo entorno organizacional, aglomerándose burocráticamente los procedimientos internos y los trámites administrativos de la ciudad.

La implementación de la LRDMQ posibilitó emprender nuevos arreglos institucionales municipales alineados con la reforma neoliberal 
del Estado. Respaldada en una amplia normativa desregularizadora y privatizadora, ${ }^{2}$ la modernización neoliberal propugnaba el ensanchamiento de las responsabilidades públicas en los gobiernos seccionales, a costa de la reducción de las funciones reguladoras del Gobierno central y la privatización de los servicios públicos. La ley de modernización facultaba al sector privado la "enajenación de la participación de las instituciones del Estado en las empresas estatales", asegurando "eficiencia, transparencia y productividad en la administración de lo público” (Ojeda 2001, 71).

El alcalde Jamil Mahuad impulsó el cambio organizacional convencido de que el municipio no podía seguir siendo solo un proveedor de servicios e infraestructura para la ciudad, tenía que convertirse en un "Gobierno local promotor del desarrollo", mediante la modernización de su estructura administrativa que debería hacerse de cara a las demandas de la ciudadanía, afirmó lo siguiente:

En lugar de una organización orientada hacia adentro y pensando cómo tratarnos mejor, quienes aquí trabajamos propendemos a una organización orientada hacia la ciudad, que piense cómo servir mejor al ciudadano que es la razón de ser de nuestra existencia, en lugar de pensar en el recurso humano como una burocracia inevitable y costosa, pensamos en el recurso humano como algo necesario y generador de ideas, planteamientos, posibilidades, en lugar de pensar que la ciudadanía tiene que aceptar lo que nosotros resolvamos, pensamos que la ciudadanía tiene su palabra que decir, debe ser escuchada y su opinión en un insumo para que nosotros diseñemos los sistemas de trabajo. (MDMQ 1995, 15)

2 Entre las que se formularon la Ley de Desarrollo Seccional en 1990; Modernización del Estado, Privatizaciones y Prestación de Servicios Públicos por parte de la Iniciativa Privada en 1993, y los Reglamentos: Sustitutivo del Reglamento General de la Ley de Modernización de 1994, y el Orgánico Funcional del Consejo Nacional de Modernización (CONAM) de 1994; el Estatuto Jurídico Administrativo de la Función Ejecutiva de 1994; la Ley de creación del Fondo de Solidaridad en 1995; la Ley Especial de Distribución del 15 \% del presupuesto del Gobierno central para los gobiernos seccionales en 1997; el Reglamento de Aplicación de la Ley Especial de Distribución del 15 \% en 1997; la Ley Especial de Descentralización del Estado y Participación Social de 1997, y finalmente la Constitución Política de la República del Ecuador aprobada por la Asamblea Constituyente en 1998. Un resumen de estas leyes puede verse en el estudio de Ojeda (2001). 
El alcalde puso en marcha la descentralización de las competencias normadas en la ley metropolitana, las que, como dije, eran una ampliación de las atribuciones municipales para robustecer el control de la ciudad, creando nuevas dependencias y formulando numerosas ordenanzas de regulación técnica. Incrementó la gestión del suelo conforme el Plan de Estructura Espacial Metropolitano (IMQ 1992), asumiendo el catastro rural que fue transferido desde el Estado central a las direcciones de Planificación, Financiera, Avalúos y Catastros, y Empresa del Centro Histórico. Con la creación de la Dirección de Medio Ambiente en 1994 (Vallejo 2009, 87-90), implementó el control y regulación ambiental de los desechos líquidos que se vierten en los cuatro ríos que atraviesan la ciudad, el control de las emisiones atmosféricas y de combustibles.

En 1994 se creó la Unidad de Planificación y Gestión del Transporte, que enlazó al sistema integrado el segundo corredor llamado Ecovía (Chauvin 2007, 90). Asumió parcialmente la competencia del transporte, pues el Gobierno central transfirió las atribuciones de planificación, regulación y coordinación del transporte público y privado, sin las atribuciones de control y recursos; no obstante, emprendió con la implementación del primer corredor del Sistema Integrado de Transporte Trolebús, lo que provocó conflictos y resistencias con el monopólico gremio de transportistas, que fueron apaciguadas con las negociaciones del alcalde.

Durante sus dos mandatos emprendió con la desconcentración administrativa (MDMQ 1998, 34-5), mediante la creación de seis administraciones zonales: Norte, Centro, Sur, La Delicia, Tumbaco y Los Chillos, a las que se delegaron funciones de gestión urbanística, recaudación tributaria, control sanitario de expendio de alimentos, mantenimiento de parques y espacios públicos, y la ejecución de pequeñas obras de mejoramiento barrial.

La participación asumida por el programa de Desarrollo Comunitario se limitó a la promoción de aisladas experiencias de microplanificación barrial, incluidas en el Plan de Desarrollo del Sur, a los planes estratégicos en las seis administraciones zonales (MDMQa 1995, 28), al malogrado Plan Estratégico de la ciudad con la efímera formación de la Asamblea de la Ciudad, activada en defensa de la capitalidad ante los ex- 
cesos que condujeron al derrocamiento de Abdalá Bucaram, y a la ejecución de pequeñas obras de cogestión con aportes de la comunidad en los barrios periféricos, especialmente en el período del alcalde subrogante Roque Sevilla (Vallejo 2009, 92). Por medio del recién creado Instituto de Capacitación Municipal (ICAM) (16), fortaleció la planificación con el entrenamiento en temas de planificación estratégica situacional, administración por objetivos y reingeniería de procesos que había emprendido el municipio capacitando a los funcionarios de las direcciones y administraciones zonales.

Con el acrecentamiento de la intervención municipal, los nuevos requerimientos de financiamiento y apoyo institucional se canalizaron mediante la cooperación internacional que había empezado el alcalde Rodrigo Paz quien, al final de su período, afirmó que "comparativamente, desde mayo de 1988, en que el Municipio no tenía virtualmente programas que cuenten con cooperación internacional, el cambio cualitativo registrado es sustancial" (Gaceta Municipal 1991, 13).

El Programa de las Naciones Unidas para el Desarrollo (PNUD) financió proyectos de manejo ambiental y transporte público, el Fondo de las Naciones Unidas para la Infancia (UNICEF) servicios básicos a barrios marginales, el Fondo de Desarrollo de las Naciones Unidas para la Mujer (UNIFEM) prestó asistencia técnica con enfoque de género, el Portal de Servicios Ciudadanos del DMQ (PAM) dio ayuda alimentaria a barrios marginales, a Oficina de Naciones Unidas contra la Droga y el Delito (UNODC, por sus siglas en inglés) apoyó proyectos de prevención de drogas, la cooperación francesa contribuyó para el desarrollo institucional, la Agencia Alemana de Cooperación Técnica (GTZ, por sus siglas en alemán) financió proyectos de gestión de residuos y control ambiental, y la cooperación belga financió la preservación patrimonial.

Con ayuda del Gobierno brasileño se realizaron eventos de capacitación en planificación. El Gobierno de España financió el sistema Trolebús, la Agencia Española de Cooperación Internacional para el Desarrollo (AECID) apoyó la rehabilitación de áreas históricas, y la Agencia de los Estados Unidos para el Desarrollo Internacional (USAID, por sus siglas en inglés) financió los proyectos de residuos sólidos y prevención de desastres. La 
ayuda italiana financió el canal frigorífico, y con recursos de la cooperación británica se realizaron obras de conservación patrimonial. Con fondos japoneses se financió la ampliación de la red de transporte público, así como el equipamiento de salud y el control ambiental; y con la ayuda de Suecia se financió el manejo ambiental. El Banco Mundial concedió préstamos para programas de recolección-disposición de residuos sólidos, e inversión en vialidad; el Banco Interamericano de Desarrollo (BID) concedió préstamos para proyectos de saneamiento ambiental y para conservación patrimonial al Fondo de Salvamento del Patrimonio Cultural (FONSAL); con apoyo del Instituto Francés de Investigación Científica y Técnica para el Desarrollo en Cooperación (ORSTOM), se emprendió el Sistema Urbano de Información, entre otros proyectos (MDMQa, 1995, 21-5).

En 1997 se promulgó el Código Municipal para el DMQ, codificado en marzo de 1999, en el que se contemplaron todas las ordenanzas actualizadas y vigentes a la fecha que regían el funcionamiento integral de las dependencias, direcciones, administraciones y empresas municipales. Era una abultada normativa municipal que puso en práctica el principio establecido por la LRDMQ de reglar las atribuciones municipales con ordenanzas, no con leyes nacionales; lo que evidenciaba que, a finales de la década de los 90, el municipio capitalino había transitado hacia una entidad de gobierno local parcialmente desconcentrada y descentralizada. Con su propia facultad legislativa, el municipio metropolitano duplicó el campo de acción pública en el distrito, pues contemplaba quince "ramos de actividad" de su administración y estructura funcional (MDMQ 1999, 33).

En la estructura orgánica se había adicionado un nivel intermedio, con lo que el municipio estaba constituido por el nivel político y de decisión integrado por el concejo y alcalde metropolitano, el nivel asesor supeditado al alcalde, el nivel de gestión con la Administración General, la Dirección General de Gestión del Desarrollo y la Coordinación Territorial, y el nivel operativo compuesto por las empresas metropolitanas adscritas y las unidades especiales creadas por el alcalde (33-4).

La facultad ejecutiva del alcalde se incrementó notablemente pues, por un lado, tenía un aparato desconcentrado en el territorio coordina- 
do por la Administración General con seis administraciones zonales: Centro, Sur, Norte, La Delicia, Tumbaco, Los Chillos, interconectadas con cinco direcciones: Planificación, Administrativa, Financiera, Higiene, y Educación y Cultura; y bajo operación directa de la Administración General las direcciones de Mercados, Medio Ambiente y Policía. Y por otro lado, un grupo descentralizado de siete empresas metropolitanas proveedoras de servicios: Centro Histórico, Empresa Metropolitana de Obras Públicas (EMOP), Empresa Metropolitana de Alcantarillado y Agua Potable (EMAAP), Empresa Metropolitana de Rastro (EMR), Empresa Metropolitana de Servicios de Transporte Terrestre y Terminales (EMT), Empresa Pública Metropolitana de Aseo (EMASEO), FONSAL y el Patronato San José (MDMQ 1998, 29). Durante las dos alcaldías de Jamil Mahuad, el municipio capitalino readecuó su estructura institucional conforme los lineamientos metropolitanos.

\section{La estructura corporativa metropolitana}

En la década de los años 2000, durante los dos períodos del alcalde Paco Moncayo, se consolidó el arreglo institucional del municipio capitalino con políticas orientadas a profundizar la descentralización asumiendo nuevas competencias, robusteciendo el holding de empresas metropolitanas y transfiriendo ciertas competencias a las juntas parroquiales rurales del distrito. Emprendió políticas dirigidas a vigorizar la desconcentración territorial en las administraciones zonales, con el incremento de sus funciones, la implantación de la participación ciudadana y el desarrollo territorial.

Las orientaciones programáticas tomaron forma en el Programa de Desarrollo Institucional, el Sistema de Gestión Participativa (SGP) y el Plan General de Desarrollo Territorial, establecidos en el plan Quito Siglo XXI del período 2000-2004, que más tarde se convirtió en el Equinoccio 21: Quito hacia el 2025 para el período 2004-2008, ambos soportados en dispositivos de gestión gerencial, planificación estratégica y gestión por resultados.

El programa de fortalecimiento institucional acentuó la tendencia de modernización de la administración municipal emprendida anteriormente, y adoptó el enfoque empresarial como parámetro de la reingeniería de procesos que se aplicó al conjunto de la estructura 
institucional. La modernización administrativa abarcaría incluso a las empresas metropolitanas como lo recomendó el concejal de más larga trayectoria, Andrés Vallejo:

Una recomendación [...] es que se traslade este proceso (la propuesta de modernización del sistema administrativo municipal) a las empresas, porque las empresas como estamos viendo [...] significan un altísimo porcentaje de lo que es la administración municipal, solo la Empresa de Agua Potable tiene aproximadamente el $20 \%$ de todo el personal del Municipio, lo que nos da una idea del volumen que esas empresas manejan y significan. (Acta 2000,25)

El propósito estratégico que guiaba la modernización institucional era el mismo desde que se inició la conversión metropolitana: convertir al municipio capitalino en un gobierno local. El enfoque establecido en los planes del alcalde Paco Moncayo, en lo sustantivo, era similar al formulado por los alcaldes predecesores, pues declaraba que la finalidad era la transformación de la administración municipal "en un verdadero gobierno local. Pasar de ser una institución proveedora y administradora de servicios públicos e infraestructuras a un sistema institucional de gobierno promotor, facilitador, organizador y regulador del desarrollo social, económico, territorial, cultural, institucional y político" del distrito metropolitano (DMQ 2000, 5). Ratificaba la continuidad metropolitana de convertir al municipio en un gobierno local para el desarrollo urbano capitalino.

Consideraba como sistémico el vínculo entre la institucionalidad municipal, la sociedad y el territorio, y era la base para el diseño y ejecución de las políticas metropolitanas, de modo que la readecuación institucional esté imbricada con el "desarrollo armónico de la región y el país” (28). El enfoque del alcalde Moncayo buscaba la sostenibilidad de los servicios metropolitanos mediante la integración sistémica de sus componentes en una perspectiva estratégica de modernización administrativa, ratificando que la readecuación institucional no era ajena a la integración de la economía local ni al progreso de la ciudad-región.

El rediseño organizacional se enlazó con la descentralización competencial y la desconcentración administrativa, renovándose las 
empresas existentes o creándose nuevas empresas, corporaciones, fundaciones y unidades operativas, con el propósito de configurar "sistemas metropolitanos” (Moncayo 2007, 10-6), para la construcción de infraestructura vial y sanitaria; para la prestación de servicios de salud y educación; para la provisión de equipamiento, seguridad, movilidad, manejo ambiental, comunicaciones y conectividad, y para promover el sistema de participación ciudadana y rendición de cuentas.

Se debía asegurar la "gobernabilidad en el distrito metropolitano", esto es la aceptación ciudadana de las políticas municipales, con la administración guiada por resultados y la "empresarización” de los servicios municipales, apoyándose en la cooperación público-privada y la coordinación institucional que permita la "gestión de nuevas competencias y proyectos metropolitanos", anunció el alcalde en su plan de trabajo (DMQ 2000, 24). El propósito de que la población sea atendida por "instituciones locales públicas y privadas, con un servicio eficiente, ágil y oportuno" (60), ratificaba el libreto original del distrito metropolitano. El holding de empresas y corporaciones metropolitanas era la condición de la operación municipal "eficiente, transparente y con resultados" (61), pues el "buen gobierno" de la ciudad se asociaba con la "creación de corporaciones y otros entes público privados que facilitan la gobernabilidad local" (2000).

Se trataba de una compleja reingeniería organizacional emprendida en un contexto nacional de recesión económica, acentuada por la dolarización decretada por el presidente de la República y exalcalde de la capital Jamil Mahuad, y por la recurrente crisis política del desgastado sistema de representación que provocó los teatrales desenlaces de sucesión presidencial en Quito. Fueron inmediatas las primeras reacciones de la prensa capitalina al anuncio del burgomaestre sobre la empresarización del municipio metropolitano:

Entonces, bajo el esquema de gestión para el desarrollo, el equipo municipal ubicó los cinco principales problemas y luego se planteó las soluciones. El principal escollo fue cómo enlazar este esquema con el de participación ciudadana, que no necesariamente implica la presencia de dirigentes barriales, sino de la empresa privada (que para Moncayo es la principal beneficiada de una ciudad en desarrollo) y de los sectores di- 
námicos de la economía. Y surgió la idea de unificar lo público y privado por medio de las corporaciones, que son entidades de derecho privado, y de la creación de empresas públicas, privadas o mixtas. Una pregunta rebota inmediatamente: ¿Se privatiza el Municipio? La respuesta es categórica: no, se busca eficiencia, la consolidación de un nuevo modelo de gobierno local más fluido y compartido. Pero también se trata de reducir la burocracia. Se habla de 14 mil empleados ahora y con todas estas iniciativas, sin despedir o renovar contratos, en menos de dos años se reduciría a 5 mil. (Hoy 2000, 2)

La reingeniería organizacional del municipio fue persistente en los dos períodos del alcalde Moncayo, sucediéndose varios hitos en la adecuación de su estructura orgánica. ${ }^{3}$ El estudio de Vallejo (2009, 100-2) sintetiza la reingeniería emprendida. En octubre de 2000 se asumió la competencia para administrar y mantener el aeropuerto Mariscal Sucre y construir el nuevo en Tababela, para lo cual se creó la Corporación Aeropuerto y Zona Franca. En el mismo año se transfirió al municipio de Quito la competencia del Cuerpo de Bomberos con la respectiva infraestructura, personal y recursos. En marzo de 2001 se ratificó la competencia del Sistema Municipal de Educación, conformado por 42 establecimientos, e igualmente se ratificaron los servicios de atención primaria de salud que prestaba el Patronato San José, que en 2001 fue convertido en fundación para fomentar "la inclusión social y solidaridad ciudadana", y más tarde en julio de 2004 se creó la Corporación Metropolitana de Salud. En julio

3 La cronología de los hitos en la reingeniería institucional es la siguiente: el 21 de noviembre de 2000 se define la estructura funcional; el 31 de enero de 2001 se estructuran las unidades y dependencias municipales; el 30 de mayo de 2002 se renombra a determinadas dependencias y se reestructuran y establecen sus nuevas funciones y responsabilidades; el 12 de diciembre de 2002 para las unidades y dependencias se denominan las principales funciones y responsabilidades que constan en el Reglamento Orgánico vigente; el 2 de febrero de 2005 se modifica la Estructura Orgánica de la Administración General; el 2 de agosto de 2005 se crea la función de los ejes estratégicos, las secretarías de Desarrollo Social, Económico y Territorial, y reagrupan las dependencias municipales acorde con cada uno y una de ellas; el 12 de diciembre de 2007 se resuelve establecer para las unidades y dependencias del municipio las competencias y responsabilidades que constan en el Reglamento Orgánico; en 2008 se decreta una resolución para que el Concejo Metropolitano autorice la adecuación constitucional de la estructura municipal (Vallejo 2009). 
de 2002 se asumió la competencia de fomento y promoción turística, formándose la Corporación Metropolitana Quito Turismo.

La municipalidad promovió políticas sociales contra la violencia intrafamiliar y a favor de la atención a personas discapacitadas, para lo que se creó el Consejo Metropolitano de Protección Integral a la Niñez y Adolescencia, y el Consejo Metropolitano de Discapacidades. Mediante la Dirección Metropolitana de Salud, creada en noviembre de 2001, empezó a ejecutar los programas del Ministerio de Inclusión Social de nutrición materna-infantil, salud escolar, maternidad gratuita y se formaron el Consejo Metropolitano de Salud y los Consejos Zonales de Salud como partes del Sistema Metropolitano de Salud. En 2007 se creó la Dirección de Inclusión Social para atender a la población de migrantes, mujeres, indígenas, afroecuatorianos y discapacitados (104-5).

La Dirección de Seguridad Ciudadana se convirtió en Consejo en 2000, y en Corporación de Seguridad en 2002 (2009). Se impulsó el Sistema Integrado de Transporte Trolebús, que operaba los tres corredores, y se fortaleció la Empresa Metropolitana de Servicios y Administración del Transporte con el Plan Maestro de Transporte y Vialidad, y la creación de la Unidad Operadora del Sistema Trolebús en 2002.

Se emprendió la gestión ambiental de la ciudad (105-8), mediante el Plan Maestro de Gestión Ambiental y la creación de la Dirección Metropolitana de Ambiente, que asumió la competencia de evaluación ambiental, otorgamiento de licencias ambientales y revisión vehicular mediante la Corporación para el Mejoramiento del Aire (CORPAIRE) en 2004, y la implementación de la Red Metropolitana de Monitoreo Atmosférico (2009). Además, se promovió la Corporación de Salud Ambiental Vida para Quito, para recuperar ríos, áreas verdes y tratar desechos sólidos.

Asimismo, con la puesta en vigencia de la Ley y Reglamento de las Juntas Parroquiales Rurales, que les confirió atribuciones y competencias, mediante la Ordenanza 185 (109-10), el municipio propició la transferencia progresiva y gradual a las juntas parroquiales de las competencias para administrar la infraestructura comunitaria; gestionar patentes; informar para la gestión de avalúos y catastros; gestionar residuos sólidos; controlar espacios, infraestructura pública y ambiental con las comisarías parroquiales. 
En paralelo, el municipio avanzó en la desconcentración administrativa conforme al Plan General de Desarrollo Territorial, fortaleciendo las administraciones zonales y creando dos nuevas: Calderón y Quitumbe, y dos delegaciones en las áreas rurales en 2001, completándose la nueva organización administrativa del distrito metropolitano que permitió "pasar de la organización municipal funcional a la territorial para posibilitar la identificación y participación de la ciudadanía en una administración municipal democrática” (MDMQ 2007, 6).

Se ampliaron las funciones de las administraciones zonales que asumieron la dirección de las dependencias municipales zonales, la planificación y ejecución de proyectos de desarrollo territorial, la administración y cuidado de los bienes municipales, la coordinación con las empresas metropolitanas para la prestación de servicios, así como las políticas municipales, la ejecución de proyectos de los sistemas de servicios municipales, la gestión urbana territorial y la representación judicial en su jurisdicción (Vallejo 2009, 110-2). Se ponía en práctica el mandato de mejorar la "atención al cliente" en el territorio, cumpliéndose el ofrecimiento del alcalde Moncayo al inicio de su gestión, cuando planteó que se buscaba operar de "forma más eficiente de lo que haría una administración burocrática tradicional (...), nuestros clientes no tienen para qué salir de su zona y en su zona tienen que ver resueltos todos sus problemas" (Acta 2000, 25).

Las administraciones zonales se acrecentaron con facultades ejecutoras, con lo que, además de prestar servicios de recaudación tributaria y trámites ciudadanos, cumplían funciones operativas de las políticas metropolitanas en sus jurisdicciones, siempre en coordinación con las empresas, corporaciones y fundaciones metropolitanas. No obstante, el alcance real de su capacidad operativa estaba en proporción al presupuesto de inversión asignado, generalmente de montos pequeños y con tendencia al ajuste, por lo que en la práctica la capacidad operativa de las administraciones zonales era mínima.

Un aspecto central en la desconcentración administrativa fue la implementación de la política municipal de participación ciudadana, la que se institucionalizó mediante las administraciones zonales, y se plan- 
teó, desde el comienzo de la administración del alcalde Moncayo, como un dispositivo para la gobernabilidad del distrito. Buscaba ir más allá del capítulo de los “derechos vecinales" contemplado en la LRDMQ, en pos de la democratización territorial, por lo que el burgomaestre propuso un sistema de participación que involucre a la ciudadanía en las políticas municipales:

una ordenanza que institucionalice la participación de la ciudadanía, mediante la puesta en práctica de mecanismos que permitan a la población ser parte del diseño de las políticas del gobierno municipal, ser actores de la planificación de su desarrollo, poder controlar efectivamente los proyectos de su interés y participar en la ejecución de sus resultados. (MDMQ 2004, 19)

A finales de 2000, mediante la Ordenanza 46, se estableció el SGP, con el propósito de conectar directamente a la administración con la población en la gestión integral del territorio, compensando los desequilibrios territoriales, asegurando equidad social, ambiental y económica, en el marco de la democratización y modernización metropolitana (Barrera 2001). Acorde con la cultura municipal quiteña, se asumió el "cabildo", una entidad municipal de larga trayectoria, como la unidad institucional de relacionamiento colaborativo entre las autoridades locales y la ciudadanía; se denominaron cabildos a las instancias de participación ciudadana organizadas conforme la escala territorial del distrito, formándose cabildos metropolitanos, zonales, parroquiales y barriales.

El SGP se definió como un complejo de instancias gubernamentales y sociales con mecanismos, procedimientos y acciones interrelacionadas que establecen vínculos predecibles y sistemáticos entre la población y el gobierno local. Se componía de dos subsistemas: el de gobierno y gestión local, que recoge en los niveles territoriales las propuestas de la participación ciudadana, y el de participación social y ciudadanía para incidir, controlar y monitorear el gobierno y la gestión municipal (2001). Los dos subsistemas estaban relacionados con la participación en la formulación de políticas, presupuesto público, planificación territorial, gestión y control social. 
En una lógica de abajo hacia arriba, se eslabonaron las instancias de participación. En los barrios y comunas se organizaban los cabildos barriales o comunales que elaboraban sus propuestas de servicios, y ejercían el control social a las políticas metropolitanas. Luego, en el nivel parroquial, estaban las asambleas o cabildos parroquiales en símil con las juntas parroquiales, en las que se agregaban y priorizaban las demandas de los barrios o comunas, según las disponibilidades presupuestarias municipales. Estas pasaban al nivel del cabildo zonal de cada administración zonal, integrados por representantes de las asambleas parroquiales y de las mesas temáticas, en el que se articulaban y negociaban las propuestas; hasta llegar al cabildo metropolitano conformado por delegados de las asambleas parroquiales y mesas temáticas, y presidido por el alcalde.

También se implementaron cabildos territoriales para priorizar por consenso las obras municipales en las zonas, al igual que cabildos sectoriales o temáticos que a escala metropolitana elaboraron planes de acción con grupos de población específicos, convocados por las diversas comisiones del municipio metropolitano: mujeres, discapacitados, niñez y adolescencia, indígenas, afrodescendientes y tercera edad.

El SGP se empezó a ejecutar desde 2001, con distintas intensidades por las variables condiciones organizativas de la población; en 2006, mediante la Ordenanza 187, se amplió a SGP, Rendición de Cuentas y Control Social. Los pocos estudios sobre esta experiencia (Novillo 2005, Torres 2008, Flor 2009, Hidalgo 2018) mostraron que la implantación del SGP-RD del municipio capitalino representó un hito institucional, complejo de operar en contextos urbanos de heterogeneidad social y diversidad cultural; demandó largas intervenciones y, exigió continuas adaptaciones, políticas consistentes y monitoreo permanente.

Representó un esfuerzo institucional relevante en la democratización del distrito metropolitano y en el ejercicio de gobernabilidad, logró acoplarse mínimamente a la estructura organizacional de las administraciones zonales, y faltó mayor apropiación de la población de los dispositivos participativos que se limitaron a la planificación y proposición de obras, pues no se avanzó en la decisión y control de las políticas metropolitanas (Flor 2009, 228). Así, evidenciando limitaciones en las 
temáticas abordadas con el procedimiento participativo, con una bajísima inversión por habitante que no superó los seis dólares, con los que apenas podía responder al $5 \%$ de las demandas presentadas en las asambleas, la participación enfrentó debilidades de institucionalización que imposibilitaron a la ciudadanía constituirse en la protagonista del proceso participativo quiteño (Hidalgo 2018, 291-5).

En lo referente a la readecuación institucional, al año 2004 el municipio tenía una estructura funcional que mantenía los cuatro niveles, a los que se habían adscrito nuevas entidades. En el nivel decisional el Concejo Metropolitano y el alcalde, al que se adicionaron el cabildo quiteño, la Comisión de Lucha contra la Corrupción, la Coordinación de Empresas, que operaba mediante ocho empresas y tres entidades metropolitanas, y la Coordinación de Corporaciones.

En el nivel asesor se mantuvieron la Procuraduría, Auditoría, Gabinete Asesor, Asuntos Internacionales y se incorporó Desarrollo Institucional, Diálogo Social, y Prospectiva Estratégica y Proyectos. En el nivel de gestión se eliminó la Administración General y se reemplazó por tres direcciones: Dirección General de Gestión del Desarrollo de la que se desprendían en el nivel operativo las ocho direcciones metropolitanas; la Coordinación Territorial operando mediante las ocho administraciones zonales; y la Administración General con operatividad en seis direcciones institucionales.

En los inicios del segundo período del alcalde Paco Moncayo, nuevamente se revisó la estructura institucional en función del Plan Estratégico Equinoccio 21, que priorizó cuatro ejes de desarrollo local: económico, social, territorial y político, con los que se redelineó la organización funcional en torno a las facultades ejecutivas, las que se vieron nuevamente robustecidas con un enorme andamiaje institucional, a la vez descentralizado y desconcentrado en el distrito metropolitano. En la reorganización institucional también se consideraron las regulaciones del Reglamento Orgánico del MDMQ, expedido en 2007.

El reglamento (MDMQ 2007) establecía que las secretarías de gestión estuvieran conformadas por las direcciones principales, mientras que las empresas, corporaciones y fundaciones se constituyeran en instancias 
de coordinación; sin embargo, para su operación dependían del Directorio y el gerente, pues gozaban de autonomía administrativa y financiera. El Reglamento Orgánico normaba las funciones específicas de cada secretaría, dirección y unidad, pero no decía nada respecto de las empresas, corporaciones y fundaciones metropolitanas, con lo que quedaban a discreción de las normas generales de funcionamiento empresarial.

Las empresas municipales se sujetan a un marco normativo amparado en la LRM, la LRDMQ, el Código Municipal para el DMQ, y en la Ordenanza 211 de 2007, que incorpora en los directorios de las empresas metropolitanas a los representantes de los consumidores, por pedido del alcalde Paco Moncayo:

hemos venido trabajando tanto, desde hace varios años, en la participación de la ciudadanía en la gestión de los temas públicos, y la falta de control desde el usuario, y esto es una de las causas para que las empresas públicas se conviertan en lo que infelizmente en el país sucede, en monopolios del político de turno que ha ganado las elecciones [...] todo el peso de los excesos paga el contribuyente o el que recibe el servicio [...] Entonces mi propuesta va en el sentido de que todas las empresas municipales de servicios públicos tengan como uno de sus miembros al consumidor, para que haya una voz de los que pagan la planilla, de los que pagan el sueldo al gerente, a los burócratas, sindicatos y a todo el mundo, no es una veeduría, es una participación del consumidor en el directorio. (Acta 2007)

Con la Constitución de la República de 2008, la Ley Orgánica de Empresas Públicas (R. O. 2009) también regula a las empresas municipales, las que se respaldan en las respectivas ordenanzas de creación de cada una de ellas. En 2010, en el período del alcalde Augusto Barrera, se expidió la Ordenanza 309 de Creación de Empresas Públicas Metropolitanas que reformaba las ordenanzas de las empresas existentes hasta la fecha, con el fin de establecerlas como empresas públicas.

Las corporaciones y fundaciones municipales, como entidades que vinculan las esferas pública y privada en la gestión de servicios urbanos, se crearon también por Ordenanza municipal conforme el Reglamento Orgánico que propende al afianzamiento del "gobierno local compartido” (MDMQ 2007, 6). Se rigen por el derecho privado, están 
adscritas al municipio con propósitos sociales y sin fines de lucro, y son responsables de la administración de los recursos públicos con el fin de gestionar eficientemente las nuevas competencias transferidas y los proyectos estratégicos establecidos en el Plan Equinoccio 21.

Si bien las corporaciones y fundaciones municipales tenían mayoría pública en sus directorios, estaban sujetas a la estructura funcional del municipio y acataban las políticas del Concejo Metropolitano, también habilitaban la presencia del sector privado en el directorio "asegurando agilidad en la toma de decisiones", recursos privados en la gestión y la materialización de los objetivos institucionales establecidos, conforme lo argumentó desde el inicio el concejal Andrés Vallejo:

La corporación tiene desde el punto de vista práctico las mismas características de una fundación, está regida por sus mismas normas legales, tiene la ventaja de que es una institución privada y que se rige por las leyes del régimen privado, sin finalidades de lucro y esto obviamente va a permitir muchísima mayor agilidad en todo el proceso que la Municipalidad tiene que llevar adelante. (Acta 2000,6)

En el primer período del alcalde Moncayo se crearon siete corporaciones y aumentaron tres fundaciones, las que se conformaron para la gestión de las nuevas competencias metropolitanas, a diferencia de las competencias asumidas mediante las empresas municipales en las administraciones anteriores. Haber optado por las corporaciones y no por aumentar las empresas municipales fue considerada una estrategia pertinente en la gobernanza metropolitana, en la medida en que facilitaba las vinculaciones del sector privado en la gestión pública local, como lo expresó la concejala Vilma Andrade en la sesión del concejo:

Quiero llamarles un poco a la reflexión de lo que ha significado la Corporación Vida para Quito, y lo que es en este momento la Corporación Aeropuerto, con la misma tasa que se manejaba la Aviación Civil, está ahora haciendo obras importantes de mejoramiento en el actual aeropuerto, esta Corporación teniendo esa connotación importante que es de unir al sector público y privado, no nos va a ocasionar ningún tipo de egreso, presupuestariamente ningún centavo, y eso quiero reconocer en la Dirección de Desarrollo Sustentable que ha generado proyectos 
con el apoyo de la empresa privada, de instituciones de solvencia, que le permiten manejar proyectos muy interesantes. (Acta 2003)

En 2005 se emprendió una nueva reingeniería organizacional del municipio capitalino. En el nivel decisional y en relación indirecta con el alcalde, se crearon dos instancias: el Centro de Mediación y la Empresa Metropolitana de Tecnología de la Información y la Comunicación. El nivel asesor se reforzó asignándole el carácter de "gestión corporativa" (MDMQ 2007, 6), con la incorporación de las Unidades de Gestión Estratégica, Asesoría de Comunicación y Diálogo Social — de la que forma parte la Radio Distrito-, y la Unidad Central del Gobierno Electrónico.

El cambio se dio entre los niveles de gestión y operativo. La anterior Dirección General de Desarrollo fue reemplazada por tres secretarías de gestión: la de Desarrollo Social organizada en seis direcciones principales: Inclusión Social, Salud, Educación, Cultura, Deporte y Seguridad Ciudadana, con cinco fundaciones, tres centros culturales, seis corporaciones y tres unidades educativas. La Secretaría de Desarrollo Económico organizada en dos direcciones principales: Promoción Económica y Comercialización, con tres corporaciones y una empresa. La Secretaría de Desarrollo Territorial contaba con dos direcciones principales: Planificación Territorial y Servicios Públicos, y Ambiental, que tenían seis empresas y dos corporaciones. La Coordinación Territorial con las ocho administraciones zonales, y la Administración General con siete direcciones institucionales (Vallejo 2009, 155). Se crearon las fundaciones Teatro Nacional Sucre y los centros culturales Metropolitano, Itchimbía, Benjamín Carrión e Instituto de la Ciudad. En suma, el aparato operativo del municipio capitalino contaba con ocho empresas, siete corporaciones, cinco fundaciones, cuatro centros culturales y ocho administraciones zonales.

Conforme se ampliaron las facultades ejecutivas, se adecuaron también las comisiones del Concejo Metropolitano en los ejes estratégicos (MDMQ 2007, 7). El eje económico estaba conformado por las comisiones de Desarrollo Económico e Infraestructura Productiva, Conectividad y Competitividad, y Comercialización. El eje social por las comisiones de Salud, Cultura, Educación, Deporte y Recreación, Equidad 
Social y Género, y Convivencia y Seguridad Ciudadana. El eje territorial por las comisiones de Suelo y Ordenamiento Territorial, Movilidad, Ambiente, Áreas Históricas y Patrimonio, y Propiedad y Espacio Público. Y el eje administrativo de Gobernabilidad e Institucionalidad conformado por las comisiones de Planificación Estratégica y Participación Ciudadana, Desarrollo Parroquial, y Presupuesto, Finanzas y Tributación.

El ajuste organizacional realizado en la segunda alcaldía de Paco Moncayo consolidó la estructura institucional del municipio metropolitano, pues reforzó estructuralmente la descentralización por medio del holding de empresas metropolitanas proveedoras de servicios, y la red de corporaciones que operaban en nuevas áreas y competencias asumidas localmente; al igual que con la desconcentración funcional en las administraciones zonales que ampliaron sus facultades ejecutivas.

Por medio del conglomerado de empresas, corporaciones, fundaciones y administraciones zonales, se extendió el campo de competencias del municipio metropolitano, pues a fines de la década de 2000 tenía bajo su responsabilidad veintidós ramos de actividad. Luego de quince años de la progresiva conversión al distrito metropolitano, de las sucesivas adecuaciones institucionales y de un sostenido crecimiento organizacional, se había logrado afianzar un modelo de colaboración público-privado para la gestión urbana que se consideraba exitoso, según lo expresó el director general de Gestión del Desarrollo del municipio metropolitano:

En Quito se han desarrollado recientemente varios proyectos exitosos, que contemplan una sostenida participación del sector público y del sector privado (desde su concepción) y generan dinámicas positivas para el desarrollo local ya que contribuyen a articular intereses diversos en torno de actuaciones de interés colectivo. [...] La experiencia y la práctica de la Municipalidad de Quito en el desarrollo de esquemas asociativos para proyectos sustantivos es importante pilar de una gestión democrática y permite cimentar procesos de gobernabilidad adecuados. [...] Algunos ejemplos de los grandes proyectos estratégicos que se desarrollan con participación público-privada en Quito son: nuevo aeropuerto de Quito, teleférico del Pichincha, promoción y desarrollo turístico, gestión ambiental (parques metropolitanos, recuperación de ríos y quebradas, forestación, revisión vehicular), seguridad ciudadana, 
recuperación del Centro Histórico, sistema de transporte público METROBUS Q, promoción de vivienda, servicios de salud (ConsaludQ), Centro Turístico Mitad del Mundo. (Carrión s. f., 184-5)

Si bien las secretarías son las instancias responsables, las empresas y corporaciones públicas tienen autonomía establecida en las ordenanzas de creación y en los reglamentos internos de constitución; en los hechos ocurrió que las empresas y corporaciones metropolitanas habían sido colonizadas progresivamente por el enfoque empresarial privado, eran empresas públicas que funcionaban con procedimientos organizacionales y gerenciales de mercado, según se evidenció en el informe de liquidación de la Empresa de Desarrollo Urbano de Quito y sus dependencias relacionadas, que estableció que se "extrajo del Derecho Público y se pasó al Derecho Privado una gran cantidad de competencias públicas" (MDMQ 2009).

Así, en el transcurso de dos décadas de continua readecuación institucional, liderada y sostenida por las autoridades locales, se consolidó la estructura corporativa del municipio metropolitano de Quito, en la que tienen mayor peso las empresas, corporaciones, fundaciones y centros por sobre las dependencias administrativas, aunque, formalmente, en el organigrama funcional estén supeditadas a las secretarías y direcciones principales.

La reingeniería organizacional emprendida con la descentralización, creando entidades para asumir las nuevas competencias, ensanchó el segmento autónomo del aparato municipal; mientras con la desconcentración en las administraciones zonales y delegaciones, se irradió los servicios de atención a la ciudadanía en el distrito metropolitano, y se extendió con limitaciones el segmento dependiente del aparato municipal.

Las readecuaciones institucionales, aparentemente, no afectaron al Concejo Metropolitano que se mantuvo limitado a las facultades legislativas, a la participación de ediles en las comisiones metropolitanas y en los directorios de las empresas, corporaciones y fundaciones. La soberanía del concejal como legislador se atenuó al convertirse en miembro de los directorios de entidades autónomas ejecutoras, en las que el alcalde ejerce un amplio margen discrecional en las decisiones estraté- 
gicas. La reingeniería organizacional ratificó una antigua tendencia de alineación empresarial que buscaba ampliarse, y consolidó el modelo de municipio metropolitano dotado de abultadas facultades ejecutivas, convertidas en poderosos brazos operadores descentralizados empresarial y corporativamente, y desconcentrados territorialmente en las administraciones zonales.

En los albores del proyecto metropolitano Fernando Carrión (1987) advirtió la tendencia de modernización del aparato municipal, con el fortalecimiento de las empresas municipales sobre las comisiones designadas por el concejo, y sobre los departamentos de gestión temática, que privilegiaba la racionalidad tecnocrática desvinculada de la política, convirtiendo a los ciudadanos en consumidores y usuarios de servicios, y desplazando la representación ciudadana y el poder del Concejo Municipal hacia las empresas municipales que en la práctica asumían la autonomía municipal.

Las distintas empresas, corporaciones y fundaciones metropolitanas creadas o adecuadas con la asunción de la normativa del distrito metropolitano, registradas en la tabla 2 - la que se elaboró teniendo como referencia la fecha de las ordenanzas metropolitanas de constitución o reforma de las entidades, aunque no constan algunas de las empresas previas a la conversión metropolitana-, permiten tener una perspectiva del holding empresarial municipal con el que opera el Municipio del DMQ.

Del creciente número de entidades metropolitanas, cada una de las cuales conlleva su propia complejidad organizacional, un específico esquema procedimental, una variedad de personal técnico y operativo involucrado, así como determinado alcance competencial, se puede colegir fácilmente que estas entidades absorben la mayor proporción de recursos y presupuesto municipal, dado que constituyen los mecanismos prioritarios para la provisión de servicios en el distrito metropolitano. Tomando como referencia el año 2009, el 80 \% del presupuesto municipal fue ejecutado por las empresas, corporaciones y fundaciones municipales, y el 11,3\% por las administraciones zonales (Bassante s. f., 55); mientras el gasto corriente representó el $8 \%$ del presupuesto, y el gasto de inversión fue del $86 \%$ del presupuesto municipal (52). 
Tabla 2

Entidades municipales metropolitanas

\begin{tabular}{|c|c|c|}
\hline Período & Empresas, corporaciones y fundaciones & Año \\
\hline Rodrigo Paz & $\begin{array}{l}\text { Fondo de Salvamento (FONSAL) } \\
\text { Empresa Metropolitana de Rastro (EMR) } \\
\text { Empresa Eléctrica Quito (reforma) } \\
\text { Empresa Metropolitana de Transporte (EMTTT) }\end{array}$ & $\begin{array}{l}1987 \\
1989 \\
1990 \\
1990\end{array}$ \\
\hline Jamil Mahuad & $\begin{array}{l}\text { Compañía Trolebús } \\
\text { Fundación Caspicara } \\
\text { Policía Municipal Metropolitana (reforma) } \\
\text { Instituto de Capacitación Municipal } \\
\text { Empresa Metropolitana de Alcantarillado y Agua Potable } \\
\text { (EMAAP) (reforma) } \\
\text { Empresa Metropolitana de Aseo (EMASEO) } \\
\text { Patronato San José (reforma) } \\
\text { Empresa Metropolitana de Desarrollo Urbano (EMDUQ) } \\
\text { Empresa Metropolitana de Obras Públicas } \\
\text { Fundación Zoológico del Ecuador }\end{array}$ & $\begin{array}{l}1991 \\
1992 \\
1992 \\
1992 \\
1993 \\
1993 \\
1993 \\
1993 \\
1994 \\
1994 \\
1994\end{array}$ \\
\hline Paco Moncayo & $\begin{array}{l}\text { Corporación Aeropuerto y Zona Franca (CORPAQ) } \\
\text { Empresa Metropolitana Quito Turismo (CORPOTURISMO) } \\
\text { Corporación de Salud Ambiental Vida para Quito } \\
\text { Cuerpo de Bomberos } \\
\text { Empresa Metropolitana de Servicios y Administración del Trans- } \\
\text { porte (EMSAT) } \\
\text { Corporación Metropolitana de Seguridad y Convivencia Ciuda- } \\
\text { dana (CORPOSEGURIDAD) } \\
\text { Corporación Parque Tecnológico } \\
\text { Empresa Metropolitana de Logística y Comercialización } \\
\text { Agencia de Promoción Económica (CONQUITO) } \\
\text { Fundación Teatro Nacional Sucre } \\
\text { Fundación Museos de la Ciudad } \\
\text { Corporación de Salud (CORPASALUD) } \\
\text { Corporación de Mejoramiento del Aire (CORPAIRE) } \\
\text { Corporación Metropolitana Quito Cultura } \\
\text { Mercado Mayorista (reforma) } \\
\text { Fondo Quito Solidario } \\
\text { Corporación Instituto de la Ciudad } \\
\text { Empresa Metropolitana de Tecnologías y Comunicación (EMITC-Q) } \\
\text { Empresa Municipal Desarrollo y Promoción de Turismo }\end{array}$ & $\begin{array}{l}2000 \\
2001 \\
2001 \\
2001 \\
2001 \\
2002 \\
2002 \\
2002 \\
2003 \\
2003 \\
2003 \\
2004 \\
2004 \\
2004 \\
2005 \\
2006 \\
2007 \\
2007 \\
2008\end{array}$ \\
\hline Augusto Barrera & $\begin{array}{l}\text { Empresa Metropolitana de Hábitat y Vivienda } \\
\text { Empresa Metropolitana de Manejo de Residuos Sólidos } \\
\text { Empresa Pública Metropolitana Metro Quito }\end{array}$ & $\begin{array}{l}2010 \\
2010 \\
2010\end{array}$ \\
\hline
\end{tabular}

Fuente: Municipio del DMQ, 2012, Índice de Carpetas del Municipio del DMQ, archivos sobre empresas, corporaciones y fundaciones. Elaboración: autor. 
La conversión organizacional siguió una trayectoria incremental, de menos a más, conforme un itinerario continuo de mejoras corporativas acorde a las directrices del gobierno local, cuyas sucesivas autoridades se alinearon, a su turno, con el proceso de evolución metropolitano. En el período del alcalde Rodrigo Paz se sentaron las bases institucionales y programáticas de la conversión al distrito metropolitano, creándose las primeras cuatro empresas municipales, dos de las cuales eran antiguas empresas municipales, y dos nuevas empresas conforme a las competencias metropolitanas, aunque todavía no se había aprobado la normativa metropolitana.

En clara continuidad, en los períodos del alcalde Jamil Mahuad, se amplió el espectro corporativo con once nuevas empresas metropolitanas; posteriormente, se consolidó en los períodos del alcalde Paco Moncayo, en los que se crearon y redefinieron diecinueve entidades metropolitanas; completándose, finalmente, el trust empresarial en el siguiente período del alcalde Augusto Barrera, en el que se formaron las restantes tres empresas públicas. En todos los períodos las autoridades locales siguieron una misma pauta de renovación institucional.

Así, transcurridos veinticinco años de la modernización institucional que amplió la capacidad operativa del gobierno local, ensamblando una constelación de entidades público-privadas para la gobernanza metropolitana, el Concejo Metropolitano había cedido poder frente al corporativismo municipal, como lo manifestó el concejal Patricio Ubidia al final de su período: "lastimosamente esto es lo que pasaba cuando las empresas dejaban de ser públicas y pasaban a ser privadas, nos limitaba la capacidad a los concejales, quienes pedíamos cuentas, pero no pasaba nada, porque les amparaba el derecho privado (...). En este caso es un municipio paralelo" (Acta 2009, 85).

Se había consumado la configuración de un gobierno local corporativo, arraigado en un entramado empresarial público declarado adecuado para la compleja gestión municipal de una ciudad expandida desordenadamente, en el que las decisiones transcendentales residen, efectivamente, en los círculos superiores del alcalde y sus decisores. Con la descentralización empresarial y la desconcentración administrativa se 
había dado paso al incremento de las atribuciones ejecutivas del alcalde y su constelación institucional, desluciéndose las atribuciones legislativas de los ediles metropolitanos. El corporativismo municipal concentró la capacidad operativa en las entidades descentralizadas metropolitanas, posteriormente denominadas públicas, y en menor proporción en las administraciones zonales desconcentradas, aunque ambas operan como brazos ejecutores del alcalde.

No obstante, coordinar la gestión de un enorme aparato institucional compuesto por 39 entidades municipales, muchas de las cuales tienen sus propios directorios corporativos y un margen de autonomía relativa, representa un gran desafío. ¿Hasta dónde este gigantesco entramado metropolitano devino eficiente para resolver los grandes problemas que afectan la calidad de vida de la población de Quito? A casi tres décadas de su progresiva creación, cuestiones como el caótico tránsito urbano carente de un sistema de transporte público, la creciente contaminación ambiental provocada por las continuas descargas residuales capilares y atmosféricas, la inseguridad ciudadana asociada con la violencia urbana, y sobre todo el desordenado crecimiento urbanístico impulsado por el trust financiero inmobiliario, no están resueltas. Aspectos neocoloniales de la convivencia entre sus habitantes, como la estigmatización de las diferencias culturales y la inferiorización de la pobreza, están ausentes de las preocupaciones y propósitos del entramado corporativo municipal.

El enfoque inicial del distrito metropolitano de dotar de una gestión estratégica al gobierno local fue reemplazado por la lógica expansiva del crecimiento institucional municipal. Un colosal corporativismo metropolitano de entidades sobrepuestas, competencialmente enredadas, fue copando a la acción pública municipal, atrapando a sus autoridades en un entramado procedimental que, paradójicamente, reduce sus capacidades de respuesta ante los acuciantes problemas urbanos; parecería que el fin último fuera el corporativismo municipal y no la gestión de la ciudad, en una suerte de ablución institucional que en vez de resolver encubre los problemas de la ciudad.

El gigantismo institucional metropolitano, cual mítico monstruo griego: la Hydra de Lerna, una serpiente gigante de múltiples cabezas ve- 
nenosas, dificulta visualizar el horizonte ofrecido de una ciudad ordenada, por lo que así como el mito griego implicó el sacrificio de la Hydra, el colosal corporativismo municipal requeriría, al menos, de podas institucionales en pos de la eficiencia para resolver los problemas de la ciudad.

\section{De la ciudad jardín a la región: Trazos y relatos}

Quito en un lapso de setenta años tuvo ocho planes urbanos, varios planes de uso y ocupación del suelo, y numerosas ordenanzas de zonificación, lo que ha generado la idea de que la capital es la ciudad más planificada del país. La existencia de los planes urbanos no necesariamente significa que Quito sea una urbe suficientemente planificada, dotada de una completa estructura funcional, con complementariedades espaciales entre lo urbano y lo rural, y que preste condiciones equitativas de vida para sus habitantes. Lejos está de eso.

Sin duda, la ciudad tiene una larga práctica de planificación que ha sido influenciada por las ideas y conceptos de las disciplinas, al igual que por los contextos históricos del país, sobre lo cual Carrión y Vallejo señalaron que los planes de la ciudad, aludiendo a los contextos, se hicieron de tres maneras sucesivas: el plan "regulador", el plan "desarrollista" y el plan en "la crisis" $(1994,16)$, a los que se podrían añadir otros dos: el plan "en dolarización" y el plan "progresista".

Entre los planes, como es de esperarse, hubo continuidades técnicas y diferencias de enfoques. Se formularon en una secuencia de menos a más, esto es en condiciones acumulativas de información y conocimientos con los que progresivamente ampliaron la mirada urbanística y la escala territorial: los primeros planes se enfocaron en el crecimiento nuclear de la urbe, los siguientes en la expansión de la ciudad y su área de influencia, y los más recientes en la dinámica territorial de la ciudad-región. Los planes compartieron la preocupación por controlar la densidad demográfica, la orientación del trazado urbano, la dotación de servicios, las áreas de vivienda, los emplazamientos de la economía, el rol del municipio y ciertas ideas del futuro de la ciudad.

La larga experiencia de planificación urbana muestra dos constantes: por un lado, hubo continuidad en la formulación de los planes, varios 
alcaldes recurrieron a ellos, otros se cobijaron en alguno precedente y lo extendieron con determinado reglamento, o aplicaron una ordenanza sustitutiva; y por otro lado, fue discontinua su ejecución, pues con la misma vehemencia con la que se planificaba la ciudad, se arguyeron múltiples factores y externalidades que impidieron su cabal ejecución: eran muy costosos, carecían de capacidad normativa, no se aprobaron en el concejo o simplemente no se aplicaron. De todas maneras, los planes urbanos, aunque en la práctica se ejecutaron parcialmente, representaron un esfuerzo municipal por pensar la ciudad, por cimentar imágenes de un futuro mediato, y sus narrativas argüían la promesa de una ciudad ordenada.

Los planes de la ciudad en el ejercicio prospectivo perfilaron iconografías de potenciales transformaciones urbanas, evidenciando hasta dónde las propuestas estaban efectivamente asentadas en la realidad, aunque muchas veces mostraron desproporciones disciplinares, por ejemplo, los fundamentos históricos generalmente fueron alegóricos, sirvieron para enlazar imágenes distantes en el tiempo con las intervenciones de corto plazo. La sociedad se volvía difusa bajo los enfoques de la población como objeto de atención de las políticas municipales, en medio de las visiones acerca de los bienes edificados, las proyecciones de la infraestructura y el equipamiento físico. En los planes reinaban las descripciones empíricas de las tendencias de la ciudad: generosos en indicadores tangibles, parcos respecto de su cultura.

Asimismo, hubo énfasis en la planificación conforme se modernizaba la urbe. Aunque todos compartían el propósito de controlar la expansión urbana, los primeros planes formulados entre los años $40 \mathrm{y}$ 70 del siglo XX privilegiaron los aspectos regulatorios urbanísticos ante el crecimiento descontrolado de la ciudad y las limitaciones municipales. Entre los años 80 y 90, en cambio, los planes ampliaron el enfoque del paisaje urbano, geográfico, económico, social y el rediseño institucional con la transición a distrito metropolitano. De los años 2000 en adelante, los planes adoptaron la perspectiva de políticas estratégicas para la consolidación metropolitana.

Paradójicamente, los planes, al interpretar la economía que sostiene a la ciudad, convirtieron la concentración económica en una for- 
taleza de la ciudad-región, con lo que velaron la comprensión del patrón de poder regional asociado con la segregación urbana, la inequidad social y la inferiorización cultural de sus habitantes. Y es que la lógica de la planificación urbana es proponer lo posible, antes que lo deseado, no caben los planes disruptores, sino los planes orientados a fortalecer el orden regulatorio de la sociedad urbana, con lo que los planes adoptaron progresivamente enfoques inclusivos, ciudadanos y participativos en pos de la democratización de la ciudad.

Los planes se asumen como instrumentos gubernamentales para el adelanto de la ciudad. Operan en calidad de conectores culturales que someten la diversidad territorial y la heterogeneidad social a la uniformidad urbana y a la homogeneidad ciudadana, recurriendo a la racionalidad medios-fines, y a la visión de progreso como condición del bienestar. Si la ciudad y el municipio son las mayores instituciones locales en la ruta de la modernidad, los planes urbanos son la bitácora del trayecto que contiene trazos espaciales y relatos culturales de la ciudad de destino.

\section{Los enfoques normativos}

Los antecedentes se remontan a los denominados "planes generales de obras públicas municipales", que acostumbraban presentar los presidentes del Concejo Municipal en los años 20 del siglo pasado para organizar el presupuesto público. Más tarde, en 1939, se intentó preparar un plan que se limitó a unas cuantas "formulaciones aisladas, espontáneas y parciales" hechas por Eduardo Pólit, a pedido del presidente del Concejo Municipal Gustavo Mórtensen (17). El inicio de la planificación de la ciudad de Quito está fechado en marzo de 1942, cuando el arquitecto uruguayo Guillermo Jones Odriozola empezó el estudio del primer plan regulador de la ciudad, a pedido del municipio capitalino, quien luego de dos años de trabajo presentó a fines de 1944 el proyecto del Plan Regulador para la Ciudad de Quito.

El plan, como lo expresó su autor, era su "interpretación emocional y estética" de una ciudad defectuosa que evolucionaba hacia una urbe populosa y moderna (Odriozola 1945, 6). Definió la ciudad como el "hogar" cada vez más limpio, sano, moral y feliz de los individuos que 
forman una familia. Con base en una visión del trabajo subdividió a la población en tres categorías: obreros, empleados, y propietarios, gerentes y administradores de las empresas, que debería tener sus barrios de vivienda cercanos al lugar de trabajo, por lo que la población se alojaría en "Zonas de vivienda: obrera, media y residencial. Zonas de trabajo: industrial, artesanado, oficinas y negocios. Zonas de esparcimiento: deportes, paseo y descanso" (7). Hizo análisis de densidad de vivienda y proyectó la ciudad para una población de 500 mil habitantes, sobre una superficie 4 416,10 ha, consideró que "los 200 mil nuevos habitantes fruto del crecimiento deberían distribuirse en los centros de la periferia como Cotocollao, Guápulo, Carrera Sur, etc.” (18).

Propuso que la ciudad se dividiera en la zona sur como el lugar de las industrias y los barrios obreros, la zona centro de empleados del comercio y oficinas públicas con sus barrios, y la zona norte con los barrios residenciales de los propietarios y gerentes, siguiendo una "tendencia natural y lógica ya iniciada por las gentes de Quito", dijo Odriozola (9). El concepto eran los barrios como unidades autosuficientes dotadas de servicios, equipamiento, centros de abastecimiento, escuelas que se diferenciaban de los lugares de trabajo por fajas de parques y zonas de transición, áreas de esparcimiento y avenidas: "La organización a base de células y barrios, la ubicación de centros cívicos, con todos los elementos necesarios para la vida casi independiente de esos barrios, su enlace por medio de los distritos con sus centros" (9), hasta unirse al gran centro de la ciudad.

Teñida de humanismo esbozó la idea regional de lo que consideraba era la ciudad: "centro de gobierno" al que concurren las fuerzas vivas, centro geográfico en el que convergen las rutas aéreas y terrestres, "centro cultural" por los "tesoros coloniales" que encierra la ciudad antigua, y centro paisajístico que atrae a las gentes a radicarse; por lo que "Quito influye en la vida y actividad de las ciudades ubicadas en el callejón interandino y que se hallan sobre las rutas que convergen o pasan por ella”, afirmó Odriozola (12). De alguna forma también era la idea germinal, en la planificación urbana, de la ciudad equinoccial.

Basado en lo que consideraba las "estadísticas de las principales oficinas de urbanismo de las grandes ciudades británicas” (1945), esta- 
bleció que las condiciones generales de agrupamiento de las gentes en Quito serían en unidades mínimas de mil personas, dotadas de viviendas, servicios diarios de alimentos, lugar de reuniones y guardería; cinco de estas unidades formarían un barrio de cinco mil personas provisto de servicios de compras, salud, alimentos y parques; los barrios, a su vez, se agruparían en ocho células barriales que formarían pequeños distritos con una media de población de 40 mil personas, equipados con servicios colectivos de hospital, teatros, centro de comercio, un gran parque, áreas recreativas, deportivas y centro de transportes (25-6). Los barrios eran la unidad espacial del plan de la ciudad jardín.

Preocupado de los espacios libres para áreas de recreación, estableció que la ciudad disponía de 73,76 ha de "espacios libres" y calculó que se necesitarían 315 ha, planteó ir a la "conquista de espacios interesantes y pintorescos", convirtiendo las quebradas en parques con rellenos y saneamiento sanitario, pues eran lugares insalubres (31). La uniformidad urbanística del espacio en el plan estaba teñida de una perspectiva civilizatoria de homogeneidad.

Sus ideas chocaron contra la realidad de la ciudad que había crecido "completamente amorfa y desorganizada", con sus distintas partes diseminadas sin criterio, los establecimientos educativos concentrados en el centro, mientras las zonas sur y norte estaban desprovistas. Para corregir los múltiples defectos que registró en la ciudad desordenada, propuso emprender grandes desplazamientos edilicios, y que el municipio adquiriera suficientes terrenos para la reorganización urbana (43). Se debía empezar por la residencial zona norte, para lo cual preparó un plan de tres pasos: primero, expropiar terrenos para la creación de parques e instalaciones; segundo, urbanizar las grandes avenidas parques que enlazarían la gran zona residencial del norte con el resto de la ciudad; tercero, construir en terrenos municipales las obras verdes y las instalaciones de juegos deportivos.

El plan de Jones Odriozola provocó revuelo entre la gente eventualmente afectada por las ideas de derrocamientos y expropiaciones que se proponían, al punto que muchas personas se "levantaron contra mí”, comentó Odriozola años más tarde, "hasta el presidente del conce- 
jo tenía que ir armado a ciertas reuniones porque había peligro de que hubiera un conato de asesinato contra él" (1991), recordó Odriozola cincuenta años después. Aunque en realidad, como lo constató en el año 1974 cuando vino a la ciudad invitado por el municipio de Quito, "muy pocas cosas se llevaron a cabo", sobre todo "no se llevaron adelante las cosas más importantes", comentó, incluso un ilustre arquitecto quiteño le obsequió un par de volúmenes sobre la planificación de la ciudad con la dedicatoria al "autor del proyecto más poético que he visto sobre Quito”, rememoró Odriozola (9).

Aunque su propuesta de ciudad jardín apenas se aplicó, el concepto de fondo del plan de Jones Odriozola sobre la ciudad dividida en tres zonas legitimó la segregación urbana de la ciudad longitudinal, confiriéndole racionalidad urbanística al empalmarla con las nociones de ejes, zonificaciones, distritos y centros especializados urbanos. Le otorgó un lenguaje urbanístico a la desordenada y excluyente urbe que encontró. Su argumentación legitimó la segregación urbana, considerándola un "acierto lógico" de la gente de Quito; era lo normal que el centro de la urbe separara la deprimida zona sur de la privilegiada zona norte, visión que se reeditaría en los siguientes planes hasta que la ciudad se extendió hacia las planicies extremas y los valles orientales, formándose nuevas centralidades en las que se reproducía, de modo sistémico, la segregación urbana.

La década de los años 60 del siglo XX estuvo influenciada por los enfoques de marginalidad y la búsqueda de bienestar económico, había que superar las culturas tradicionales que obstaculizaban el progreso, proclamaba el modelo desarrollista en ascenso, en el que la planificación nacional tenía un papel relevante como instrumento de programación del futuro. Eran las ideas que cobijaban a los proyectos de industrialización, reforma agraria, vivienda, artesanías y cooperativas que el Estado con la Junta Nacional de Planificación (JUNAPLA), el sector privado y la ALPRO promovían en el país.

El ambiente en la capital era de expectativa ante las primeras iniciativas privadas mutuales de acceso a la vivienda multifamiliar, estimuladas por la ALPRO y con la creación del Banco Ecuatoriano de la 
Vivienda (BEV) impulsó los pioneros programas de vivienda "de interés social". El crecimiento urbano en torno a la vivienda empezaba a mostrar proporciones insospechadas, develaba un paulatino alineamiento de bancos privados, empresas constructoras, las nacientes mutualistas y el propio municipio, por lo que se hacía necesario contar con un cuerpo normativo municipal que reglamente el crecimiento urbano experimentado por la ciudad.

Al inicio de la alcaldía de Jaime del Castillo se aprobó, mediante la Ordenanza 1165 de julio de 1967, un plan de vocación reglamentaria que se había elaborado en el transcurso del año anterior, denominado Plan Director de Urbanismo. El nuevo plan no planteó un modelo disyuntivo de ciudad como el de Odriozola, sino que se inclinó por los trazos urbanísticos antes que por el relato urbano, y se propuso reglar el crecimiento de la ciudad haciendo algunas proyecciones de nuevos emplazamientos espaciales. El plan director combinaba los estudios técnicos y las propuestas de regulaciones urbanísticas.

Carrión y Vallejo (1994) sintetizaron el contenido del plan director que estuvo organizado en cinco secciones. La primera contenía el estudio de la ocupación del territorio, en la que se clasificaron los usos del suelo y las condiciones técnicas de las edificaciones, distinguiendo entre los "usos residenciales, unifamiliares, bifamiliares, multifamiliares, el equipamiento de la ciudad" y el equipamiento vecinal; de los usos industriales, áreas verdes y otros servicios, a cada uno de los cuales se le asignaba una distribución de población (20). La segunda sección tenía una suerte de código de arquitectura en el que se establecían las especificaciones y estándares de usos del suelo, tamaños de lotes, dimensiones de retiros, alturas, etc.; era una reglamentación para edificaciones principalmente de vivienda.

La tercera sección, basada en el reconocimiento de la forma policéntrica que adquiría la ciudad, propuso diferenciar entre el equipamiento urbano que correspondía al conjunto de la ciudad del equipamiento de vecindad y el equipamiento barrial, apoyado en estudios de reubicación del centro de gobierno, los terminales terrestres y el aeropuerto en Calderón (20). La cuarta sección comprendía un análisis de la "zona histórica de la ciudad", y la quinta sección planteó un sistema vial que 
conecte el sur y el norte mediante vías de circunvalación y túneles que atraviesen el centro, siguiendo la forma longitudinal de la ciudad (20).

Como lo señalaron Carrión y Vallejo, el plan director no contempló el análisis regional, y aunque se enfocó en el aspecto físico de la ciudad, no tuvo la instrumentalización adecuada ni el financiamiento necesario, por lo que no se ejecutó; sin embargo, la normativa reglamentaria sí se aplicó y se mantuvo vigente hasta entrados los años 90, reglando la configuración edilicia capitalina (20). Poco después, en 1971 la Ordenanza 1353 declaró a la ciudad y sus periferias como Centro de Desarrollo Urbano de Emergencia, denominando a esa zona como Área Metropolitana de la Capital de la República (IMQ 1992, 14-5), con una estructura territorial de área urbana definida por el límite de abastecimiento de agua potable, área suburbana o área de expansión de la ciudad, áreas urbanas y suburbanas de las parroquias rurales, y área rural.

Seis años más tarde, en la alcaldía de Sixto Durán Ballén, se emprendió con un nuevo plan denominado Quito y su Área Metropolitana, Plan Director 1973-1993. El contexto nacional había cambiado, pues los años 70 fueron el período en que el Gobierno militar emprendió el mayor esfuerzo de planificación nacional, enlazando su reformista proyecto "nacionalista y revolucionario" que impulsaba el desarrollismo y el crecimiento económico con epicentro en las ciudades, las que se expandirían como los núcleos de la economía. En el caso de Quito, estimuló el exponencial crecimiento urbano por su condición de destino privilegiado de las inversiones provocadas por el del auge petrolero de esos años. El lugar del progreso eran las ciudades.

El plan que había elaborado el municipio capitalino combinaba la orientación para regular el crecimiento inmobiliario y el tránsito de la ciudad con un enfoque desde ya autonomista en lo local, mientras la acción programática gubernamental era de articulación nacional; no obstante, el estudio del plan metropolitano, concluido en 1973, representa la primera "conceptualización" municipal, de alcance público, sobre la región de la ciudad (Carrión y Vallejo 1994, 23). El estudio abarcaba "cuatro planes de desarrollo: espacial, social, institucional y económico", pero acabó proponiendo un "esquema de ordenamiento 
territorial" basado en la "densificación y descentralización parcial" del área metropolitana. El estudio no fue considerado ni aprobado por el Concejo Municipal (23), aunque más tarde, algunos de sus elementos fueron retomados en el siguiente plan de la ciudad.

A comienzos de los años 80 , el país se encontraba agitado con la transición a la democracia que había sido diseñada por la clase política quiteña, que elaboró una nueva Constitución en 1978 y trazó el esquema de partidos políticos que se implementó a comienzos de la década. En la ciudad emergían numerosos partidos, movimientos y coaliciones políticas en reemplazo de los tradicionales partidos, mientras las maquinarias electorales se repartían los barrios.

Por su lado, el municipio enfrentaba una creciente complejidad en la gestión de la ciudad, la que recién había asumido una nueva condición internacional: la Organización de las Naciones Unidas para la Educación, la Ciencia y la Cultura (UNESCO) declaró a Quito Patrimonio Cultural de la Humanidad el 8 de septiembre de 1978. La urbe había mudado su anterior configuración compacta y longitudinal: pasó a una policéntrica formada por la macrocentralidad de las zonas gubernamental, residencial, financiera y comercial; en sus costados surgieron numerosos asentamientos humanos precarios, promovidos por la especulación del suelo, y se conurbanizaron algunas de las cabeceras parroquiales de los valles orientales circundantes. La ciudad se había extendido en una superficie mayor que amplió el perímetro urbano.

El alcalde Álvaro Pérez, con el auspicio de la Agencia para el Desarrollo Internacional, impulsó la realización de un plan de ordenamiento que encontrara soluciones integrales a los desequilibrios urbanos provocados por la expansión, con el propósito de lograr el "bienestar social, mejoramiento económico y ordenamiento urbanístico de la población y la ciudad" (IMQ, 1980, 14), por lo que a fines de 1980 se presentó el denominado Plan Quito que fue aprobado por el Concejo Municipal en enero de 1981. Desde el inicio, el plan reconoció la nueva condición metropolitana de la ciudad, conformada por la existencia de "microrregiones" con incidencia sobre las actividades y la población que se asientan en la ciudad, y la definió de la siguiente forma: 
tanto a nivel económico como social, Quito se ha constituido en un núcleo alrededor del cual se organiza un amplio conjunto de fenómenos diversos y heterogéneos. A nivel económico, es un hecho que esta ciudad aparece como la cúspide de una larga cadena, a la cual se ha hecho referencia. Es, por decir de alguna manera, el centro organizador de una multiplicidad característica del tipo de desarrollo implementado en el país. (24)

El plan problematizó el concepto en boga por esos años de "polo de desarrollo", argumentando que en la ciudad no se había dado la gran industrialización y concentración poblacional como ocurrió en otras urbes, se trataba más bien de una peculiar alineación de "núcleos organizadores" que integran una "cadena que culmina en el núcleo mayor" de Quito, configurado con relación a la Sierra y al resto del territorio nacional. Se planteó que la tendencia ecuatoriana en la formación de áreas metropolitanas, al contrario de los casos de homogenización y consolidación, era el mantenimiento de las características previas de las localidades y las zonas integradas a la ciudad, por lo que más que área metropolitana debería hablarse de "microrregiones o áreas de influencia” funcionales al desarrollo de la urbe.

El área de influencia se expresaba en un espacio indefinido con solapamientos rurales y urbanos, por lo que presentaba "problemas de delimitación" de la superficie del área metropolitana y la que queda por fuera, de ahí que se consideró que sería más adecuado "hablar de un área de influencia o microrregión” (25-6). Asimismo, señaló que una deformación del estilo de crecimiento que la ciudad había adoptado era la progresiva "incorporación de áreas rurales" a la trama urbana, con la "implantación de nuevas urbanizaciones legales e ilegales"; proponía que la política urbana para Quito "requería más de una consolidación y racionalización del área existente, que de una incorporación de nuevas áreas” (27).

El plan declaró tres niveles de objetivos. A nivel del país, buscaba consolidar la capitalidad; a nivel regional, equilibrar la dinámica intrarregional; y a nivel de la ciudad, estructurar un espacio unitario de Quito y su microrregión, racionalizar el funcionamiento de la ciudad, conservar el área histórica, preservar la imagen urbana, armonizar la ciudad y su medioambiente, dirigir el crecimiento urbano con la orga- 
nización racional del espacio urbano, la distribución de los servicios y equipamiento básicos, canalizar el asentamiento espontáneo, promover la participación y coordinación institucional, y fomentar las organizaciones sociales (53-4). El Plan Quito, al menos desde sus objetivos, visualizó la erradicación regional de la ciudad capital.

Estableció un horizonte temporal hasta el año 2000, se declaró obligatorio para la municipalidad y referencial para los agentes de desarrollo. Puntualizó que era un plan de ordenamiento urbano, esto es que no da "pautas sobre el desarrollo económico y social de la ciudad, sino más bien crear y ordenar el marco espacial que haga posible ese desarrollo" (57); por lo que instauraría normas de carácter técnico y jurídico que canalizarían y regularían el desarrollo físico espacial de Quito y su microrregión, como "un todo unitario".

Operativamente, el plan dividió al área metropolitana de acuerdo a los usos del suelo y a las densidades demográficas en once distritos, distribuidos cinco en el área urbana, y seis en la microrregión: San Antonio, Calderón, Tumbaco, Los Chillos, Turubamba y Aeropuerto (1716), este último en la planicie de Tababela donde se había proyectado la implantación de la nueva terminal aérea, con acceso por una vía perimetral. Los estudios sectoriales de las catorce áreas temáticas de soporte del plan se organizaron de acuerdo con los once distritos, y los eventuales planes maestros de agua potable y alcantarillado, energía eléctrica, comunicaciones, vías y transporte considerarían a los distritos.

El plan planteó políticas generales para el desarrollo de Quito y su microrregión, a partir de tres consideraciones generales. Se debía asumir a la capital y su microrregión como un "nuevo concepto de unidad de planificación, dentro del contexto político-jurídico del país, e implementar los mecanismos que permitan lograr esa jurisdicción" (623); esta afirmación aludía a que se debía reconocer al distrito metropolitano como un nuevo nivel de la división político-administrativa, como efectivamente ocurrió con la aprobación de la LRDMQ una década más tarde.

Planteaba la "necesidad de coordinar los planes de desarrollo microrregionales establecidos por la municipalidad", con el plan nacional de desarrollo para asignarle el rol que debe cumplir la microrregión 
dentro del contexto nacional (623); esta otra afirmación, hecha probablemente con buena intención, simplificaba la dinámica histórica, económica y cultural de la región de Quito respecto del país, debido a que el enfoque sincrónico excesivamente diagnóstico y poco propositivo del plan impedía comprender el rol jugado por la región de la Sierra centro norte con núcleo en Quito.

La asignación de roles a las regiones desde el Estado central como compensación a sus aportes al país requiere de la subsidiaridad regional (Stöhr 1999), algo de lo cual se había emprendido en la década anterior, mediante la formación de entidades regionales autónomas en varias de las regiones desatendidas. La vinculación de Quito, en cambio, era inversa: antes que el Estado le asignara un papel más allá de la capital del país, la región quiteña había configurado su heterónoma relación con el Estado nacional por medio de los poderes regionales. La declaración del plan en este aspecto era retórica, desconocía la dinámica regional y era contradictoria con su propia afirmación de Quito como el eslabón final de un encadenamiento mayor.

La demanda de que se considere a Quito y su microrregión como un "todo unitario", sometido a un mismo plan integral de desarrollo físico para la preservación y crecimiento urbano, aludía a la inevitable innovación institucional del municipio capitalino para efectivamente hacerse cargo de la problemática metropolitana, no era suficiente con declararla, sino que requería su modernización organizacional para emprender con la gestión integral de un territorio mayor al centro urbano.

De ahí que las acciones inmediatas que propuso el plan empezarían con la desconcentración administrativa de los organismos nacional, municipal y privados, constituyendo centros de equipamiento y servicios en los distritos propuestos en él. Se impulsaría una trama de acuerdos operativos para la primera fase del plan, con los agentes urbanos, los gobiernos seccionales de los cantones y provincia aledaños, junto con la consolidación del distrito centro norte como el núcleo político, administrativo y económico de Quito (IMQ 1980, 637).

El Plan Quito, pese a declararse normativo para fines de regular el desarrollo urbano de la ciudad, se limitó a los estudios diagnósticos de soporte que fueron bastante detallados, pero no logró formular las pro- 
puestas operativas de acción pública, y tampoco montó el corpus técnico y jurídico anunciado, con lo que no consiguió mayor trascendencia institucional; aunque un año después con base en sus planteamientos se formularon el Plan de Ocupación del Suelo y el Código de Arquitectura y Urbanismo, que tampoco se aprobaron en el Concejo Municipal (Carrión y Vallejo 1994, 24). No obstante, el Plan Quito representó un esfuerzo por dotar de una visión metropolitana al municipio capitalino, aunque su mirada se limitaba al área de influencia de la ciudad dentro del cantón Quito.

\section{La perspectiva de transición}

Una década después, en pleno auge de la reforma neoliberal del Estado en la que adquirían notoriedad los municipios, con la emergencia en varios cantones de las pioneras experiencias de gobiernos locales participativos, los que se mostraban innovadores frente al desgastado Estado nacional, en la alcaldía de Rodrigo Paz, en 1992, se presentó el denominado Plan Distrito Metropolitano alineado con el mandato constitucional de crear el DMQ (IMQa 1992). El plan, soportado en el mayor conjunto de estudios realizados desde el municipio sobre la ciudad, se desplegaba en un extenso programa editorial de dos fases: la primera contenía los estudios y propuestas estructurales del crecimiento urbano, y la segunda las intervenciones proyectadas en la planificación.

El plan partía de un diagnóstico que confirmaba la condición de ciudad segregada, que había adoptado un desarrollo urbanístico excluyente de "miles de sus habitantes", con una configuración territorial de características especulativas, y organizaciones sociales en las que primaba lo económico. La ciudad había desembocado en una situación de “desgobierno" (Acta-O 1990). El municipio había perdido su condición de administrador de la ciudad, en medio de una institucionalidad público-privada con competencias superpuestas que enredaban la gestión urbana, provocando crónicos problemas de transporte, la crisis de la centralidad, mientras una cuarta parte de la población estaba asentada en los barrios periféricos en condiciones de pobreza.

El plan se propuso tres objetivos generales: "Delinear los mecanismos de gestión y administración gubernamental” para que el Conce- 
jo Municipal recupere el control del desarrollo de la ciudad, en coordinación con los gobiernos locales, el Estado nacional, las organizaciones sociales y el sector privado. Establecer las condiciones adecuadas para los asentamientos humanos satisfaciendo las demandas de empleo, suelo, vivienda, servicios, equipamiento, transporte y abastecimiento en condiciones de preservación del medioambiente y seguridad preventiva ante los riesgos naturales. Y adoptar un sistema de planificación integral que incluya los aspectos espaciales, y el desarrollo social, económico y administrativo del cantón (IMQa 1992).

El Plan Distrito Metropolitano, en consecuencia, se organizó en tres programas. El de Gobierno Metropolitano para estudiar la base territorial del área metropolitana, establecer sus límites y las formas adecuadas de división especial, la nueva organización territorial de la ciudad y sus áreas de influencia, para revisar las adecuaciones organizacionales de la administración municipal, actividades que convergieron en la propuesta de LRDMQ.

El Programa de Desarrollo Socioeconómico que planteaba comprender el rol económico del distrito metropolitano y las características de su futuro desarrollo.

El Programa de Desarrollo Espacial Metropolitano, orientado a satisfacer las demandas de ordenamiento territorial, con un nutrido corpus de estudios técnicos y planes sectoriales de la estructura espacial metropolitana, relacionados con el desarrollo zonal, el modelo urbano-ambiental, la vivienda metropolitana, el plan maestro del Centro Histórico, el programa de infraestructura metropolitana, el proyecto de reglamentación urbana, el plan de desarrollo urbano parroquial, la programación anual municipal, el sistema urbano de información, el plan de localización y fomento industrial, el proyecto de protección de sistemas ambientales regionales, y el plan de protección de riesgos naturales, sísmicos y vulcanológicos (IMQ 1992, 19). En el plan de la estructura espacial metropolitana se planteó la concepción de un nuevo territorio:

El distrito metropolitano, bajo una forma de división territorial, cuyo núcleo orgánico constituyen las zonas (conjuntos barriales y parroquiales, con representación política en el Concejo Municipal) que 
tendrían cierta autonomía administrativa, política e incluso financiera. La ciudad quedaría dividida en cuatro grandes zonas: Turubamba y Urinsaya, al sur; Yavirac en el Centro Histórico; y Anansaya al norte de la capital. Las parroquias rurales se dividen en seis zonas integrando cada una de ellas actividades afines y homogéneas. Se busca, en el mediano plazo, especializar los usos del suelo en cada zona y dotar de todos los servicios e infraestructura necesarios a los pobladores (IMQa 1992).

El Programa de Estructura Espacial Metropolitana, a su vez, se planteó como un plan especializado de ordenamiento general del territorio. Propuso como objetivos "precisar el rol del distrito metropolitano en la organización territorial regional y nacional”, mediante un plan de ordenamiento territorial; establecer los límites del distrito y las áreas de expansión, los patrones generales de uso del suelo; crear condiciones de autonomía en las zonas del distrito; determinar la demanda regional de equipamientos urbanos; establecer áreas de intervención prioritaria; ordenar la información; establecer el sistema vial regional; preservar el medio ambiente, y la conservación de las áreas históricas. Se consideraron tres horizontes temporales: el corto plazo, 1992-1996, para los planes operativos; mediano plazo, 1996-2000, para ajustes al inicio del nuevo período municipal; y largo plazo, 2010-2020 (IMQ 1992, 20), para la gestión metropolitana de la ciudad.

En el horizonte de largo plazo se fijó una "imagen objetivo" para el distrito metropolitano, con la que se "pretendía inducir una variación en la tendencia de concentración de la población” en la ciudad, de modo que se equilibren los balances entre demografía, servicios y equipamiento urbano. Había que orientar el crecimiento poblacional hacia los centros urbanos importantes de la región, promoviendo su conurbanización, junto con programas de ocupación urbana y mejoramiento de la infraestructura básica, pues la ciudad "ha rebasado los límites naturales de su área" incorporando un territorio que "no puede ser planificado ni administrado con los instrumentos de gobierno y planificación existentes”, se decía (IMQa 1992, 16). La nueva imagen de Quito requería una configuración policéntrica desconcentrando las funciones del espacio central en el resto de la ciudad y la región. 
En esa perspectiva se volvía ineludible una readecuación organizacional del municipio que asegure formas eficientes de participación popular. Se propuso dividir el territorio en cuatro zonas urbanas metropolitanas denominadas "centrales", cada una estaría integrada por cuatro parroquias urbanas relativamente homogéneas, y seis zonas suburbanas con las veinticuatro parroquias rurales que constituirían el área metropolitana (1992).

El análisis de las actividades económicas arguyó la conveniencia de mantener la actividad industrial en el ámbito metropolitano, por sus implicaciones laborales y poblacionales, pero habría que hacer reubicaciones según el tipo de industrias y los riesgos contaminantes. Del mismo modo, se decía que era preocupante la "pérdida de áreas agrícolas por la especulación del suelo y la urbanización”, ante lo cual se consideraba imprescindible conservar las áreas agrícolas y pecuarias para que "entren en producción agresiva y dinamizar la agricultura de exportación". Sobre las actividades financieras que se habían apropiado del espacio urbano central, si bien constituyen el mayor rubro del desarrollo local y nacional, requieren un estudio particular sobre la nueva organización del espacio y las actividades financieras (IMQ 1992, 20).

El plan planteó la necesidad de una nueva organización general del territorio metropolitano, confrontando la tendencia de "ir adscribiendo territorio de la periferia a la ciudad central", con la organización de unidades territoriales o zonas que vayan resolviendo las relaciones centro-periferia, el equilibrio urbano-rural, junto con una administración descentralizada eficiente en la prestación de servicios y promotora de la participación de la comunidad (24). En el marco del plan se materializaron varios proyectos: el Sistema Urbano Informatizado, las normativas Reglamento Urbano de Quito y Código de Arquitectura y Urbanismo, y varios planes de intervención: el Plan Zonal Turubamba, el Plan Ciudad Quitumbe y el Plan Maestro del Centro Histórico de Quito en el contexto de la transición a distrito metropolitano.

Los planes de intervención se implementaron parcialmente a lo largo de los años 90 y siguientes, y el enfoque estratégico del Plan Distrito Metropolitano sirvió de "hoja de ruta" en la implementación de la transición al distrito metropolitano durante las dos alcaldías de Jamil Mahuad. 


\section{Las vocaciones estratégicas}

A comienzos de los años 2000, el ambiente en Quito era de azoramiento por la reciente dolarización decretada en 1999, que provocó una fraudulenta concentración de capitales financieros, descapitalización de las medianas y pequeñas empresas, una estampida migratoria junto con el fenómeno de envío de remesas, un abrupto descenso del PIB nacional con la consecuente restricción en las finanzas públicas, la agudización de la crisis política y una creciente ola de protestas sociales.

El alcalde Paco Moncayo ganó las elecciones en el año 2000 y se reeligió en 2004, elaboró un plan de gobierno de continuidad para los dos períodos; el primero se denominó Plan de Desarrollo Integral Quito Siglo XXI, y el segundo Plan Equinoccio 21, ambos tuvieron el mismo enfoque y compartieron las directrices estratégicas. En el primer plan el propósito central era modernizar la gestión del gobierno de la ciudad, y mejorar la gobernabilidad democrática, institucionalizando la participación ciudadana en la toma de decisiones, en la asignación de recursos, el control social y la rendición de cuentas (Moncayo 2010, 12).

La propuesta de planificación para la ciudad se delineó en el Plan de Desarrollo Territorial formulado en 2001 y actualizado en 2006, con el que se buscaba consolidar el distrito metropolitano definido como "el hogar para una significativa población para el tercer milenio, espacio cotidiano donde los quiteños tendrán que vivir y convivir” (MDMQ 2009, 15), pero que requería efectuar transformaciones integrales para mejorar la calidad de vida, afianzar la democracia, permitir habitar con dignidad y seguridad en un ambiente saludable y sustentable, en el que la solidaridad y el respeto rijan el "comportamiento de los vecinos", declaraba el plan.

En el diagnóstico del plan se argumentaba que el distrito metropolitano tenía múltiples atributos y potencialidades, pero también un conjunto de problemas relacionados con un territorio "ambientalmente disminuido", socialmente quebrantado, segregativo e inseguro, su identidad ciudadana era imprecisa; adolecía de un crecimiento urbano expansivo y desequilibrado, un creciente menoscabo del patrimonio histórico, una tendencia a la concentración espacial y excluyente de los servicios, la infraestructura básica era insuficiente, inadecuado gerenciamiento del 
tráfico y transporte, dotación restringida de vivienda, escaso y deteriorado espacio público, además de una gestión inapropiada del espacio rural, un marco institucional incompleto y escasos recursos económicos (156). Ante esta realidad, si no se actúa con energía y visión de futuro, esos problemas pueden agravarse, por lo que lo primero era "salir del hoyo", declaró el alcalde en su informe de labores de mitad de período.

En la visión del burgomaestre la base de un manejo "racional, equilibrado y sustentable" del distrito metropolitano implicaba la relación entre la gente y el territorio, por lo que el gobierno municipal debe cumplir la "intrincada tarea de anticiparse al futuro para impulsar con fuerza el desarrollo del distrito". Definió el territorio como una "oportunidad para afianzar procesos de integración internacional, nacional y regional", promoviendo las vinculaciones que exigen el entorno económico, político y tecnológico "del mundo contemporáneo para alcanzar prosperidad y distribución adecuada de satisfacciones materiales y espirituales" (16-7).

Consideraba a Quito en el contexto nacional como un polo de inmigración, un espacio de "alta concentración económica y poblacional" que había establecido múltiples interrelaciones con las provincias circundantes. Declaraba que "El Distrito Metropolitano de Quito es también centro de decisiones económico-financieras de carácter nacional y regional, centro turístico, cultural y educativo con potencialidad de desarrollo tecnológico; es una región de producción y consumo de escala" (19). Se entendía a la región como un complejo de tres espacios diferenciados por articulaciones territoriales e interacciones de procesos mancomunados, en procura del desarrollo integral. El modelo de espacio región se planteaba como

Un espacio dinamizador: el Distrito Metropolitano. Un espacio articulador de las estructuras interregionales: la provincia de Pichincha. Varios espacios activos de desenvolvimiento regional: las provincias colindantes o no, que compartan y asuman el proyecto de desarrollo mancomunado. Nichos y mercados internacionales. (20)

Asimismo, esbozó una visión de futuro en torno a potenciar el distrito metropolitano, sobre todo su capitalidad para asumir de mane- 
ra irreversible nuevas atribuciones, funciones y recursos para gestionar el desarrollo local. El plan buscaba condiciones adecuadas de vida para su gente, al igual que la "competitividad de sus actividades", integrando al país como "eje generador de nacionalidad", un espacio ordenado, con bienestar y solidaridad, con óptima calidad ambiental y estética. Un "territorio seguro ante los riesgos ambientales y la violencia social", solidario con la calidad de vida y el derecho a la ciudad, competitivo y consolidado como un "centro macro regional y nacional de decisiones políticas, financieras y empresariales”, un “Quito gobernable y democrático" (30-4), declaraba en sus intenciones.

Lo que se denominaba "la vocación estratégica de Quito" (2009, 37-8) se derivaba de su condición de capital del país, su localización geoestratégica y escala territorial. Ratificaba la predisposición de la urbe como "nodo económico y territorial", con capacidad de articulación de la diversidad productiva, generadora y proveedora de servicios. Se afirmaba que la realidad económica, funcional, cultural y simbólica de la ciudad era su disposición trascendental como ciudad competitiva.

En la actualización del plan, en 2004, se incluyeron las nociones de "sociedad del conocimiento y geopolítica del conocimiento" (2004, 7-8). La ciudad-región se entendía también como el "espacio de innovación”, constituido por un sistema regional innovador que solo puede ser consecuencia de la conjunción de "agentes públicos, privados y académicos" que "interactúan en un territorio específico aprovechando una infraestructura particular para adaptar, generar y difundir innovaciones tecnológicas” (6). El concepto era que las ciudades-región exitosas son las que crean un entorno de innovación, respaldado en la certeza, decía, de que la realidad ha mostrado que las empresas e instituciones que generan economía e innovación tecnológica tienden a asentarse en las zonas urbanas metropolitanas.

La visión de Quito respecto del país se había mantenido: la ciudad es el eje de la nacionalidad, pues como capital, historia y cultura representa el "símbolo que configura la nacionalidad ecuatoriana" (15). Se ratificaba su condición de centro político, económico, empresarial, administrativo, turístico, educativo y cultural de alcance nacional y regional, nodo privilegiado de comunicaciones e intercambio entre per- 
sonas, bienes y servicios debido a su localización. Se amplió la mirada de Quito y su región que presentan algunas ventajas comparativas: ubicación geoestratégica, infraestructura y servicios, cultura productiva, economía diversificada y la existencia de ciertos sectores económicos que han penetrado mercados internacionales con éxito. Son factores, se decía, que pueden devenir en ventajas competitivas superando el atraso tecnológico, la baja productividad y la "mentalidad y cultura poco inclinadas a la internacionalización” (9).

El plan se declaraba alineado con el desarrollo humano sustentable: "El ser humano está en el centro de la planificación” (26-7). Se decía humanista, en tanto propendía el adelanto cultural para la transformación y el crecimiento de las personas. El plan puntualizaba que era estratégico con un horizonte hacia el año 2025, formulado a modo sistémico, en concordancia con la comprensión del distrito metropolitano como el subsistema de los sistemas provincial y nacional, en un entorno mundial. Como un "pacto nacional", basado en la adhesión y concurrencia de las "voluntades de los más diversos grupos de la colectividad quiteña", buscaba orientar "solidariamente los esfuerzos de la comunidad, hacia fines democráticamente acordados" (16).

En un lenguaje facundo la visión de futuro declaraba a "Quito capital del sol, ciudad próspera y atractiva, democrática y solidaria, centro estratégico y turístico, eje cultural de América" (17). Para su puesta en práctica se fijaron nueve políticas generales para superar los problemas existentes en la ciudad: profundización del proceso de descentralización municipal, construcción participativa de una cultura ciudadana, promoción de la productividad, competitividad y empleo, implantación de la justicia social con equidad, potenciación del territorio como recurso sustentable y equitativo, enriquecimiento del patrimonio protegido, prestación de educación universal de calidad, promoción del entorno familiar con fortalezas, y una gestión pública transparente y de calidad (17-8). Las políticas estaba asentadas en una estrategia de competitividad que pensaba a Quito como distrito tecnológico, nodo de conectividad avanzada y centro de una región de alto desarrollo agrícola, agroindustrial y turístico, con el objetivo de 
convertir a Quito en un macro cluster de servicios avanzados, que apoye los procesos productivos existentes en su reconversión y puesta al día, que cree las condiciones favorables para la generación e implantación de nuevas actividades económicas y que empuje la modernización tecnológica e institucional del conjunto del aparato productivo de la región. (18)

Los servicios avanzados como eje del desarrollo económico y de la modernización productiva del distrito metropolitano, se decía, eran la manera de "incorporar al progreso a la mayoría de unidades productivas económicas" de la región, sin "exclusiones de escala, rama, localización o mercado" (32-3). El plan se organizó en cuatro ejes estratégicos del desarrollo en los que se enlazaban los proyectos y las actividades.

El eje económico centrado en la economía productiva, competitiva y diversificada para el bienestar de la población (2004) promovería una cultura de la innovación, calidad y eficiencia en la sociedad y sus instituciones, mientras el municipio era el responsable de crear el "entorno favorable" garantizando la seguridad jurídica, el territorio ordenado y con infraestructura, movilidad y equipamiento de servicios.

El eje social dedicado a construir en el distrito metropolitano una sociedad equitativa, solidaria e incluyente que respete la diversidad cultural, una ciudadanía con educación de calidad, salud, vivienda digna, acceso a cultura, deportes, recreación, suficientes espacios públicos, con fácil movilidad y preferencias a los grupos vulnerables. La ciudad equitativa e incluyente garantizaría el acceso universal a la información, el conocimiento y las herramientas tecnológicas y culturales, el derecho a la libre expresión, pensamiento y manifestación cultural, a una equilibrada inversión en el territorio (2004). Ofrecería el más alto nivel educativo, académico, cultural, de salubridad, y una mejor calidad de vida a sus habitantes.

El eje territorial que buscaba convertir al distrito en un territorio racional y eficazmente ocupado, con equidad social y sostenibilidad ambiental, dotado de equipamiento productivo, social y servicios, infraestructuras modernas y eficientes para la conexión interna y externa (2004). Provisto de un sistema equilibrado de asentamientos urbanos en red para desarrollo local y regional, con uso y conservación 
de agua y recursos naturales, que estimula la inversión privada a partir de la explotación sostenible innovadora y eficiente de sus localidades, y la articulación de la región quiteña con las regiones vecinas mediante mancomunidades.

Y el eje político para avanzar hacia la constitución de una cultura ciudadana que haga posible la construcción democrática de lo público; afiance su gobernabilidad en democracia; propicie normas de convivencia, comunicación y la concertación en la solución pacífica de sus conflictos; promueva el respeto al patrimonio común, el cumplimiento de deberes y derechos ciudadanos, así como la confianza en el valor que sustenta las prácticas sociales ciudadanas. Ir hacia un distrito metropolitano gobernable y democrático supone seguridad ciudadana, libertad frente al miedo, ausencia de violencia, respeto a la ley y el cumplimiento de las reglas (2004). Una imagen por todos compartida, sustentada en un sistema de comunicación socialmente construido que garantice información a los ciudadanos sobre los logros colectivos, afirmaba.

Posteriormente, la Constitución de la República de 2008 declaró el buen vivir y el Estado plurinacional e intercultural, anunciando que el país entraba en un umbral posneoliberal, que no necesariamente significaba poscapitalismo, por el que el Gobierno nacional, de postura progresista, emprendió una sostenida reforma democrática del Estado constitucional de derechos, robusteció el financiamiento del presupuesto estatal y amplió la esfera pública con una enorme inversión en los sectores social, vialidad, producción y energía. Montó un complejo institucional y normativo para el acceso universal a los servicios públicos, en una suerte de tardío Estado desarrollista inspirado en el distante Estado de bienestar.

El alcalde Augusto Barrera, adscrito a las filas del gobernante movimiento PAIS y electo en 2009, presentó el denominado Plan Metropolitano de Desarrollo 2012-2022 que, literalmente, se convirtió en el último plan de la ciudad. El plan conectaba el mandato constitucional del buen vivir con el DMQ, al que consideró como una "ciudad de derechos y derecho a la ciudad", su territorio como un "espacio de interacción", y a Quito como una ciudad-región (MDMQ 2012). La noción del buen 
vivir implicaba que "cada uno de los objetivos, políticas, programas y metas del Plan contribuirían al afianzamiento de una sociedad justa y solidaria que reconozca las diferencias y busque equidad con base en la interculturalidad"; que combine el ejercicio de los derechos individuales y colectivos, promueva "oportunidades para todos/as y privilegie el bien común, la cohesión y justicia social, sin afectar las libertades de elección individual, ni la afirmación de las múltiples identidades” (10), declaró el nuevo plan de la ciudad.

Mantuvo el enfoque de ciudad-región que se desprende de su condición de capital, por su "posición geopolítica estratégica", por su potencialidad como Patrimonio Cultural de la Humanidad, la "conectividad regional, nacional e internacional”, y por ser sede de las entidades públicas, organismos internacionales, financieros, culturales y comerciales. (MDMQ 2012). Preveía que asumirá nuevas competencias según las normas de autonomía y descentralización para convertirla, a corto plazo, en el primer gobierno autónomo con las competencias de región (10). Se consideraba que el distrito metropolitano era al mismo tiempo una ciudad-región y un gobierno autónomo, en el que se irían afianzando los derechos constitucionales del buen vivir, mientras avanzaba en la integración de los territorios contiguos en busca de un "posicionamiento estratégico global en los intercambios comerciales, en la ciencia, la tecnología y en la gestión de los recursos naturales" (18).

El plan propendía a acoplar el distrito metropolitano al nuevo modelo de desarrollo integral, inclusivo y de productividad sistémica declarado en la Constitución de 2008 (18). Se guiaba por los proclamados principios de primacía del ser humano sobre el capital, un distrito en el que prevaleciera la función social y el interés general, el rescate de lo público, una modernización integradora e incluyente, y una gestión democrática del territorio con la movilización social y el ejercicio de ciudadanía.

El modelo de desarrollo sustentable que se presentaba para el distrito metropolitano debería garantizar el buen vivir con "políticas de inclusión y equidad”, que regularan el régimen urbanístico, el uso del suelo y el sistema de participación ciudadana (19). Proveer los servicios públicos de agua potable, alcantarillado, depuración de aguas residua- 
les, desechos sólidos y saneamiento ambiental. Promover la actividad turística, la economía social y solidaria, el derecho al hábitat y la vivienda, y los derechos de los grupos de atención prioritaria. Regular la contaminación ambiental, el espacio público y el crecimiento ordenado de las actividades económicas, empresariales y profesionales. Patrocinar las culturas, artes, deportes y recreación (19). Preservar el patrimonio edificado y natural. Y planificar y regular el transporte terrestre, la vialidad urbana y la seguridad ciudadana.

Para ello había que revisar la estructura territorial del distrito, de modo que se potenciaran las "interdependencias entre los cantones vecinos"; se redujeran los impactos ambientales urbanos con un desarrollo sustentable; se fortaleciera la "cultura distrital policéntrica", con la dotación universal y equitativa de servicios e infraestructura física; y se garantizara el acceso universal al espacio público y al territorio distrital conectado (19). Se anunciaba una reorganización funcional del espacio metropolitano.

Había que frenar el crecimiento de la "mancha urbana" (37), asegurando el desarrollo sustentable rural, las reservas de suelo; se densifiquen las zonas según su capacidad de carga y se contenga el crecimiento disperso de los bordes de la ciudad. Generar una oferta de vivienda saludable, hábitat seguro y reducir la población en condiciones de riesgo. Preservar el patrimonio cultural edificado; dotar al distrito de áreas equipadas productivas, redes e infraestructura de servicios básicos; preservar los ecosistemas distritales del sistema hidrológico, la biodiversidad y flora, regulando el uso y ocupación productiva del suelo; y proveer equipamientos equilibrados de servicios sociales y espacios públicos en las centralidades rurales (19). Los servicios públicos se extenderían equitativamente a todos los rincones del distrito metropolitano.

El plan contempló siete ejes estratégicos. Uno: Quito ciudad capital, distrito-región, que fortalecería al distrito como capital y nodo articulador de la ciudad-región, sus interrelaciones, representatividad y referencialidad como modelo de desarrollo y ordenamiento territorial, privilegiando el territorio ordenado y una ciudad con centralidades alineadas en dirección a su autonomía (2012). Dos: Quito accesible para la ciudadanía, en el ejercicio de derechos ciudadanos articulados a la uni- 
versalidad, accesibilidad y sinergia, con contrapartes de cumplimiento de deberes y responsabilidades ciudadanas. Tres: Quito vida y convivencia, relacionado con el derecho a la vida y convivencia, en una ciudad consolidada, densificada y policéntrica, resolviendo las demandas de movilidad, espacio público, hábitat y vivienda (20).

Cuatro: Quito productivo y solidario, dirigido a fortalecer el pleno empleo, la economía diversificada en ramas productivas y tipología de emprendimientos, para consolidar la ciudad de los emprendedores, la innovación y la competitividad sistémica (2012). Cinco: Quito verde, con la conversión a distrito sustentable mediante la preservación, mantenimiento y protección del patrimonio natural, mejorando la calidad ambiental y contribuyendo a mitigar los efectos del cambio climático. Seis: Quito milenario, histórico, cultural y diverso, orientado a potenciar la condición de Patrimonio Cultural de la Humanidad, fortalecer la identidad quiteña en la diversidad, garantizar la activa vida cultural y la recreación del patrimonio tangible e intangible. Siete: Quito participativo, autónomo y democrático, implementando la gobernabilidad que consolide el modelo de gestión metropolitano desconcentrado, integral y participativo (20).

En el análisis de la estructura regional del distrito metropolitano, el plan reconoció que su condición regional era parte de la histórica "bicefalia" del sistema de centralidades del país, marcado por Quito y Guayaquil. Se había fortalecido por su condición de capital política y administrativa del país, como un nodo de conectividad y economía dinamizador del desarrollo regional caracterizado por la interdependencia y el contacto laboral, flujos de servicios, abastecimiento de consumo y movilidad entre el distrito y sus jurisdicciones de los cantones limítrofes, la provincia de Pichincha y las provincias vecinas. "Todo ello le confiere un rol y relevancia regional en el centro norte del país, lo cual, en términos territoriales se manifiesta en un desbordamiento de sus límites físicos y administrativos, así como en procesos de conurbanización con los cantones vecinos" (21).

Argumentó que entre el distrito metropolitano y los nodos o conglomerados urbanos hay relaciones funcionales de flujos de servicios, personas, bienes articulados a los sectores productivos y reproductivos, 
el abastecimiento y procesamiento de alimentos, suministro de materia prima, partes para la manufactura y los sistemas de comercialización de bienes nacionales e importados. Por su lado, el distrito brinda a la región servicios administrativos del Gobierno central, genera empleo y provee equipamientos comerciales, logísticos, educativos, de salud, recreativos y culturales regionales, nacionales e internacionales.

El plan avizoraba la articulación regional en torno a la capitalidad, convertida en nodo del desarrollo social y económico con la aglomeración urbana de municipios vecinos, cruzado por relaciones físicas, económicas y sociales, y desplazamientos de población. Se requerían adecuaciones que programen y articulen un modelo de sustentabilidad participativo e incluyente en el territorio regional inmediato, reconociendo y potenciando los roles e interdependencias territoriales entre el distrito y los cantones vecinos. Había que avanzar hacia un desarrollo urbano y rural eficiente y sustentable, que reduzca las inequidades territoriales y los impactos ambientales del proceso urbano metropolitano en el territorio inmediato y regional (28). Asimismo, había que obtener el estatuto jurídico del distrito autónomo; y promover la conectividad, inserción y articulación estratégica con otros territorios locales y globales mediante uso de las capacidades locales, la gestión del conocimiento, ciencia, tecnología y el diálogo de saberes.

En lo sustantivo las políticas del plan referidas a la ciudad-región estaban dirigidas a erigirlo como un distrito autónomo, con ejercicio de competencias propias que le permitan ejecutar agendas intercantonales de ordenamiento territorial, conurbanizaciones, movilidad, productividad y sostenibilidad; así como regular el crecimiento de la mancha urbana, promoviendo reservas de suelo, el uso sustentable del suelo rural y urbano; y fortalecer la estructura policéntrica con la dotación equitativa y universal de servicios sociales e infraestructuras básicas, movilidad y transporte público integral. Se buscaba también avanzar en los sistemas regionales de corredores ecológicos, y en ampliar los espacios públicos y áreas verdes. El plan declaraba gestionar el "conocimiento como una construcción cultural”, basado en el diálogo de saberes ancestrales y contemporáneos, el acceso democrático a los beneficios de la ciencia; 
consolidar la participación ciudadana en las políticas metropolitanas, y promover los espacios de gestión del conocimiento entre barrios y comunas (28).

$\mathrm{Al}$ igual que sus predecesores, el último plan de la ciudad se mostraba extenso en sus declaraciones, objetivos y propósitos, pero impreciso en sus implicaciones de acción pública, el diagnóstico de la realidad metropolitana predominaba sobre las políticas urbanas, al menos en el relato urbano que continuaba encuadrado en el formato de los planes anteriores.

¿Cuál es el simbolismo de orden, progreso e inclusión subyacente en las narrativas de los planes urbanos reseñados? El largo relato planificador que empezó con el esbozo de la ciudad jardín hasta delinear la ciudad-región, más que códigos de una urbe imaginada, revelan los signos de una promesa urbana de orden, en medio del desorden territorial provocado por las dinámicas espaciales de los negocios inmobiliarios, industriales, comerciales y el mencionado desgobierno de la ciudad, acaecido desde mediados del siglo XX. La preocupación compartida en los planes urbanos, con distintos matices e intensidades, giraba en torno a ordenar la desorganización urbana generada con el paso de la urbe tradicional a la ciudad metropolitana, y que dio lugar a la formulación de los nueve planes urbanos de Quito, enlistados en la tabla 3.

Los planes muestran la secuencia de intervención municipal en el ordenamiento urbano de la ciudad, junto con el paulatino despliegue de una visión enfocada en la ciudad primero, y paulatinamente en la ciudad-región. Los primeros planes destacaron el crecimiento urbano descontrolado de la ciudad, mientras el plan de transición delineó el esquema de gobierno y la estructura espacial metropolitana para su control, y los subsiguientes planes se orientaron a la consolidación del distrito metropolitano, enfatizando en las políticas estratégicas territoriales, gubernamentales y económicas. Contenida en los argumentos del conjunto de la experiencia de planificación capitalina, estaba la promesa del orden urbano. 
Tabla 3

Planes urbanos de Quito

\begin{tabular}{|l|l|l|}
\hline \multicolumn{1}{|c|}{ Año } & \multicolumn{1}{|c|}{ Planes } & \multicolumn{1}{c|}{ Carácter } \\
\hline 1939 & Plan de Eduardo Pólit & $\begin{array}{l}\text { Compendio, antecedente de plani- } \\
\text { ficación. }\end{array}$ \\
\hline 1942 & $\begin{array}{l}\text { Plan Regulador para la Ciudad de } \\
\text { Quito de Jones Odriozola }\end{array}$ & $\begin{array}{l}\text { Regulador, racionalizó la segrega- } \\
\text { ción urbana. }\end{array}$ \\
\hline 1967 & Plan Director de Urbanismo & Reglamentario y urbanístico. \\
\hline 1973 & $\begin{array}{l}\text { Quito y su Área Metropolitana: } \\
\text { Plan Director 1973-1993 }\end{array}$ & $\begin{array}{l}\text { Regulador, autonomía y enfoque } \\
\text { regional. }\end{array}$ \\
\hline 1981 & Plan Quito, esquema director & $\begin{array}{l}\text { Normativo, desarrollo urbano y } \\
\text { área de influencia. }\end{array}$ \\
\hline 2000 & $\begin{array}{l}\text { Plan de Desarrollo Integral Quito } \\
\text { Siglo XXI }\end{array}$ & $\begin{array}{l}\text { Transición metropolitana, gobierno } \\
\text { y estructura espacial urbana. }\end{array}$ \\
\hline 2004 & $\begin{array}{l}\text { Consolidación del distrito metropo- } \\
\text { litano, región, vocación estratégica. }\end{array}$ \\
\hline 2009 & $\begin{array}{l}\text { Plan Equinoccio 21 } \\
\text { llo 2012-2022 }\end{array}$ & $\begin{array}{l}\text { Ciudad-región, sociedad del cono- } \\
\text { cimiento y desarrollo humano. }\end{array}$ \\
\hline
\end{tabular}

Fuente: Planes urbanos de Quito, distintos años. Elaboración: autor.

La promesa de orden fue la manera discursiva de asumir el progreso y la modernidad en la ciudad, enfocada en la gestión metropolitana y la adecuación del gobierno local que faciliten, en acuerdo con sus principales fuerzas económicas y políticas, la regulación del entorno espacial para los negocios de la economía regional, y paliar la segregación urbana y social creada con la dinámica regional. Se materializó con la asunción del distrito metropolitano y sus dispositivos reguladores, cuyo diseño reproducía las jerarquías urbanas con la concentración elitista de las decisiones estratégicas, afianzaba la autonomía municipal sobre los recursos públicos, y la creciente conversión empresarial en la prestación de servicios, infraestructura y equipamiento. 
No era una promesa de cambio que modifique las contradicciones urbanas, menos aún que compense las inequidades territoriales de una ciudad que había crecido descontroladamente, obedeciendo a los impulsos del complejo financiero inmobiliario quiteño. Aunque los planes reconocieron la persistencia del crecimiento urbano excluyente, revertir la segregación urbana supone enfrentar el poder en la ciudad, cuestión que los planes no se propusieron, se trataba más bien de gestionar la segregación urbana y la exclusión social en medio del orden espacial de la economía regional y las jerarquías de la sociedad quiteña.

En la promesa del orden urbano los distintos planes apenas proyectaron el crecimiento deseado de la urbe, calcularon cuantitativamente el crecimiento de los emplazamientos espaciales de las actividades urbanas, en medio de un débil desarrollo urbanístico. No pensaron la complejidad urbanística de la ciudad, su expansión se medía comparándola con el centro urbano compacto, de modo autorreferido: la ciudad creció con referencia a la centralidad urbana en las primeras décadas, más tarde convertida en macrocentralidad metropolitana.

Las narrativas de planificación buscaban "racionalizar" el desorden territorial, partiendo de la continuidad espacial del centro de Quito, pues todos los planes, a su modo, aceptaron la virtualidad de la ciudad emplazada en un territorio con centralidad geográfica, lo que le confería cualidades de atracción social, económica y cultural. La ciudad jardín se refirió a su condición de centro paisajístico como elemento de sugestión, los planes reguladores subsiguientes aludieron al emplazamiento equinoccial como eslabón de un encadenamiento mayor o como nodo de conectividad, y los más recientes planes explícitamente aludían a la geografía solar de la ciudad-región competitiva.

El orden urbano de la ciudad compacta y las áreas de expansión era posible en una ciudad administrada por zonas, cuestión que también fue enunciada en todos los planes. La racionalidad planificadora clasificó a la urbe desde el centro hacia los costados, ensayando sucesivas taxonomías de zonas, distritos, áreas, subáreas y centros, siguiendo el patrón de segregación urbana reconocido en el primer plan: el sur obrero e industrial, el centro de los empleados y gobierno, y al norte los propietarios y 
empresarios, el excedente de crecimiento poblacional debería alojarse en las parroquias aledañas. Tendencia que se volvió endémica y que los sucesivos planes legitimaron, pues, a su turno, reconocieron la formación de un área cada vez mayor a la ciudad compacta, a la que denominaron área rural, suburbana, área de influencia o microrregión, hasta que se asumió como el área metropolitana de la ciudad-región quiteña.

\section{Mapa 2 \\ Sistema policéntrico}

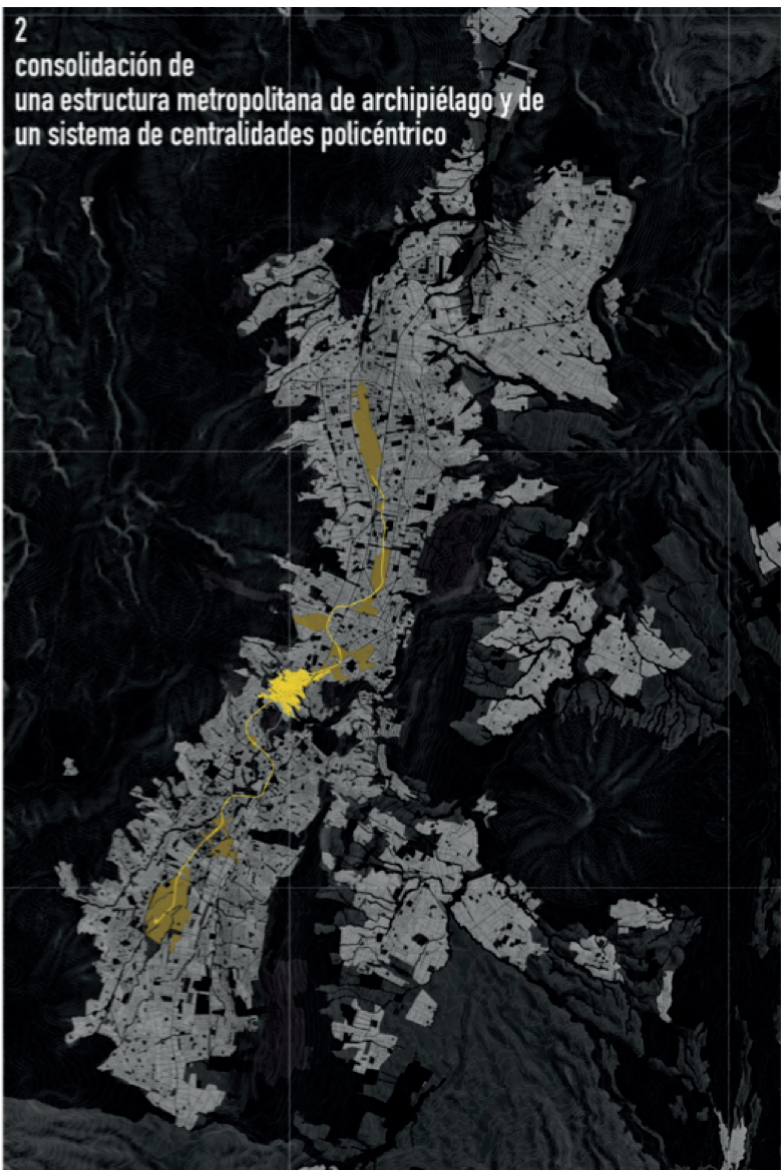

Fuente: MDMQ, 2012, Diagnóstico Estratégico-Eje Territorial. 
Así, a partir de la antigua centralidad de Quito devenida en moderna macrocentralidad metropolitana dispersa o de archipiélago, las zonas administrativas gestionan el área del distrito metropolitano, dentro de las cuales también se reproducen de modo sistémico la segregación urbana y la exclusión social, en medio de una distinción estructural entre el norte y los valles orientales, respecto del centro, el sur, los costados y extramuros metropolitanos de la ciudad. En la nueva configuración espacial de la ciudad, cada uno de los planes contribuyó a ajustar la visión de una estructura metropolitana esparcida en el territorio, con un sistema de centralidades policéntrico, como puede verse en el mapa 2; aunque cabe señalar que la forma que adquirió la urbe no es consecuencia de la planificación, sino de su escasa concreción. Los planes interpretaron operativamente la realidad urbana, pero poco influyeron en modificarla.

En todas las zonas administrativas el crecimiento urbano somete a las áreas rurales, reproduciendo el desorden territorial por la especulativa manera con que se incorporan las tierras rurales convertidas en urbanizaciones, ciudadelas y lotizaciones, o en algún tipo de formación urbana por las arbitrarias implantaciones industriales, áreas comerciales mezcladas con áreas residenciales, reeditándose en las zonas las microurbes compactas y áreas de expansión. Los planes acabaron legitimando la segregación urbana del urbanismo desigual, con lo que la promesa del orden urbano es simbólica, en la práctica se reproducen las jerarquías de la ciudad quiteña y el desorden territorial necesario para el avance de los intereses inmobiliarios, comerciales y financieros locales.

A la promesa de orden le acompañaba la visión del progreso urbano. Los planes anunciaban sus propósitos de avance y bienestar para la ciudad, dotándola del trazado urbano adecuado, de las condiciones básicas de habitabilidad, vivienda y abastecimiento, para lo cual hicieron trazos urbanísticos de los emplazamientos deseados o proyectados. Conforme crecía la ciudad, los planes también aumentaban la escala espacial, incorporaban la complejidad creciente en la dotación de servicios básicos, equipamiento e infraestructura.

El progreso urbano, en la retórica de los planes, no era solo consecuencia de la intervención pública, sino también derivación de las fun- 
ciones de la ciudad, de sus fuerzas económicas y fortalezas internas que conducen a su adelanto; al municipio le compete proveer los entornos favorables a su consecución. Los planes revelaban el afán institucional del avance de la urbe, buscaban la consolidación de sus funcionalidades espaciales en la región, el país y la globalización. Anunciaban que el crecimiento económico competitivo era el factor determinante de la riqueza que provee el bienestar material, ese era y es el sentido del progreso de la ciudad.

En el enfoque de la ciudad jardín se esbozó el progreso urbano en torno al trabajo, las empresas y los obreros. Los siguientes planes reguladores lo hicieron en referencia a la adecuación de los asentamientos industriales, comerciales y abastecimientos productivos. En los preámbulos metropolitanos, el progreso se asumía como soluciones integrales que incluían los aspectos sociales, físicos y culturales en torno a lo que empezó a formularse como la ciudad competitiva. Los últimos planes abiertamente declararon que el propósito era convertir al distrito metropolitano en un nodo de la ciudad global, centro financiero, productivo y comercial con carácter empresarial y competitivo; matizado, en el último plan, también como una ciudad equitativa y solidaria.

El crecimiento económico, que posibilita el progreso urbano, estuvo presente en todos los planes de la ciudad, corroborando la denominada "vocación estratégica de la ciudad", con la que se ratificó su condición de capitalidad y al mismo tiempo eje de la región económica quiteña, devenida, en el presente, como la capital económica del país por la mayor aglomeración empresarial en el distrito metropolitano. En los planes urbanos la concentración económica y la capitalidad están enlazadas, confieren sentido de pertenencia e identidad al distrito metropolitano como región competitiva.

El progreso urbano quiteño se valida con la mirada externa, desde afuera se mide el avance de la condición moderna de la urbe, ha sido el argumento en todos los planes de la ciudad. En el plan de la ciudad jardín se juzgó el avance con los indicadores de lo que se llamó "las más importantes oficinas de planificación británicas”. Los siguientes planes reguladores declararon "estándares de funcionalidad propios de las urbes mundiales", 
pues carecían de estándares propios. Más tarde, los planes integrales abogaron por la comparación de la ciudad en el contexto internacional, unos arguyendo un inexistente "polo de desarrollo" optaron por los "núcleos organizadores"; otros propusieron el enfoque de "nodo competitivo" de la capital del país frente a otras capitales en la globalización.

Los últimos planes declararon a la ciudad como parte de la red de ciudades globales, en las cuales el referente de autopercepción son los rankings de ciudades que ubican a las urbes según sus capacidades de albergar negocios, o su condición metropolitana se juzga por su inserción en los nodos de la "red urbana global", por la ubicación de las ciudades según sus propias fortalezas. De cierta manera, es la contemporaneidad en la valoración de la ciudad andina desde la exterioridad, considerándola con los estándares de las ciudades modernas occidentales.

La continuidad colonial en la mirada externa atravesó los planes de la ciudad. La idea naturalista de la ciudad jardín como la "ciudad-centro", derivada de su ubicación en una geografía "telúrica" equinoccial, abierta a todos los que en ella quieran asentarse, setenta años más tarde sigue vigente en el enfoque de que la ciudad tiene una "fortaleza innegable de su origen: la condición geográfica de ser una ciudad en la mitad del mundo que le otorga una centralidad que debe aprovecharse y el modelo de ciudad abierta que ha construido la obliga a encontrar un nicho en la red urbana global" (Carrión y Dammer 2011, 20). La naturaleza andina equinoccial de la ciudad de Quito, paradójicamente, se valora desde la exterioridad de la modernidad urbana.

No obstante, los planes urbanos contienen también una dimensión democratizadora de la ciudad. La preocupación por compensar la segregación urbana y modificar los desequilibrios territoriales provocados por la economía y el mercado capitalistas está presente, con distintas intensidades, en todos los planes de la ciudad. Igualmente, la intención de intervenir en la tendencia de absorción de los territorios circundantes por parte de las centralidades urbanas que configuran la ciudad y el área metropolitana de Quito, en función de avanzar en una organización territorial no conflictiva, ha sido manifiesta en los planes de la ciudad. 
Cada plan, en su momento, propuso extender los servicios básicos de agua potable, alcantarillado sanitario, el tendido de energía eléctrica, los trazados de calles y avenidas, el acceso del transporte público, la dotación de equipamiento comunitario, deportivo, parques y mobiliario en los barrios periféricos que se formaron en los costados de la urbe. Proveer de servicios básicos en el marco de la lógica normativa y programada de la planificación ha sido la manera pública de disminuir la discrecionalidad de las autoridades locales en el uso de los recursos públicos, especialmente de enfrentar el clientelismo político profundamente enraizado en los barrios populares y periféricos de la capital.

La visión estratégica del conjunto del espacio urbano metropolitano caracterizó los planes de la ciudad. Desde distintas ópticas se buscó orientar la inversión pública, compensando las inequidades territoriales principalmente en los sectores más empobrecidos de la ciudad, con lo que la parcial ejecución de los planes urbanos los convirtió más en artefactos discursivos que en dispositivos prácticos de redistribución de la riqueza generada en la ciudad. Igualmente, el mayor o menor apego de las acciones municipales a la planificación urbana reveló el carácter inclusivo, abierto a la ciudadanía, de la esfera pública en la ciudad.

Aunque las proyecciones urbanas, las visiones de futuro y las previsiones territoriales de los planes fueron rebasadas en todos los casos por el crecimiento urbano, los planes urbanos, sus mentores, ejecutores y la institucionalidad municipal, más allá de las rutinas burocráticas en que se vieron envueltos y de las racionalidades técnicas a las que recurrieron, revelaron los afanes democratizadores del gobierno metropolitano capitalino.

En suma, los planes contienen piezas del relato público de la racionalidad instrumental, con la que se pensó y se moldeó el orden deseado de la ciudad de Quito. ¿Hasta dónde efectivamente se aplicaron y consiguieron ordenar la ciudad? Es un tema que merece conocerse en profundidad, no para atribuir supuestos impactos a los planes, cuestión que sería excesivamente artificiosa, sino para conocer con certeza los factores políticos y económicos del desorden urbano que conllevan la inequidad, segregación y estigmatización de buena parte de sus habitantes. 
Los alcances narrativos de los planes forman parte de la memoria reciente de la ciudad, registrada desde la mirada de quienes la planificaron, en un comienzo humanista y regulatoria, posteriormente integral y normativa, y recientemente inclusiva e intercultural ante las diferencias sociales y espaciales que la constituyen. Sus trazos y relatos dejan ver la trayectoria, cada vez más intensa, de Quito hacia la moderna ciudad-región competitiva.

\section{En la ruta de la región metropolitana}

La asunción del DMQ representa figurativamente el punto de "no retorno" en la trayectoria de la modernidad colonial de la ciudad-región, las cifras de los cambios ocurridos en la urbe en las recientes décadas lo evidencian. Desde la declaración del distrito metropolitano, si se compara a la ciudad de los períodos anteriores, esta disminuyó su ritmo de crecimiento urbano.

Su extensión para el año 1995 era de 16 452,6 ha, que equivalían a un crecimiento del $4 \%$; para 2003 el tamaño de la ciudad aumentó a 27 473,1 ha, que representaban un incremento del $67 \%$; tres años más tarde, en 2006, su tamaño alcanzó las 32889,4 ha, que equivalían a un crecimiento del 19,7 \%; y en el año 2011 su tamaño era de 43551 ha, con un crecimiento equivalente al 32,4 \% (Instituto de la Ciudad 2013).

El DMQ ocupa una superficie de $4235,2 \mathrm{~km}^{2}$, alberga el 15,5\% de la población nacional; su territorio está dividido en ocho administraciones zonales, que contienen 65 parroquias, de las cuales 32 son urbanas y 33 rurales, como puede verse en el mapa 3. La población del distrito aumentó de 209399 habitantes en 1950, a 2239191 en el año 2010, crecimiento demográfico que está relacionado principalmente con la expansión urbana. De acuerdo con los datos censales, la población total del distrito a 2010 es de 2239 191: 1088811 son hombres y 1150380 son mujeres; en el área urbana de Quito hay 1619145 habitantes, y en el área rural 620045 habitantes (MDMQ 2012, 13). 


\section{Mapa 3}

\section{Parroquias del Distrito Metropolitano de Quito}
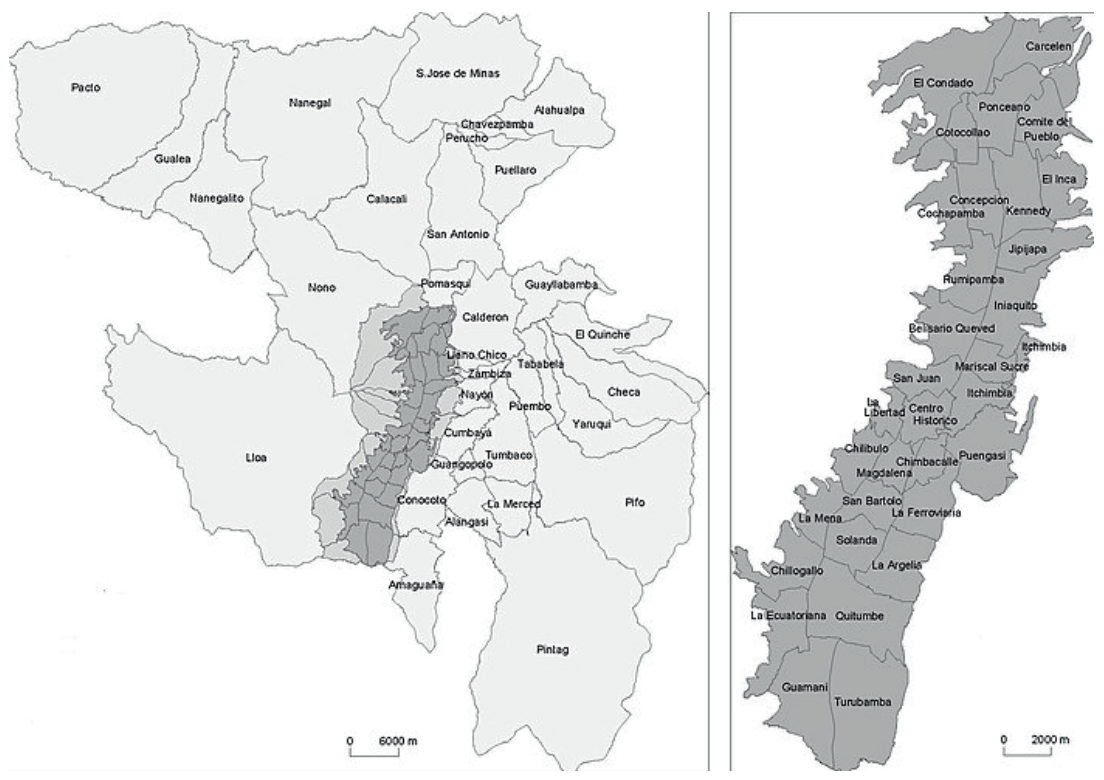

Fuente: MDMQ, 2012, Diagnóstico Estratégico-Eje Territorial.

Según el último censo nacional, el DMQ tiene casi 400000 habitantes más que en 2001, la población actual del distrito representa el 86,9 \% de la población de la provincia de Pichincha, y se estima que para el año 2022 su población será de 2,8 millones de habitantes, de los cuales el 68,7 \% residirá en el área urbana. La comparación de la población urbana y rural en el último período intercensal muestra una disminución de la población urbana que en 2001 representaba el 76,6 \%, y en 2010 fue de $72,3 \%$; mientras la población rural en el mismo período se incrementó en 4,3 puntos porcentuales, evidenciando una tendencia poblacional de asentamiento en las áreas en consolidación ubicadas en los extremos norte y sur de la ciudad, y en los valles de Los Chillos y Tumbaco (14).

A nivel territorial, "menos de la mitad de los quiteños reside en la ciudad consolidada”, en las zonas administrativas Eloy Alfaro (sur), Manuela Sáenz (centro), Eugenio Espejo (norte), "frente al 56 \% que 
en el año 2001". En el período intercensal la zona Manuela Sáenz perdió población residente, al tiempo que las zonas Eloy Alfaro y Eugenio Espejo la incrementaron. El mayor aumento poblacional fue en las áreas en proceso de consolidación: Quitumbe, Calderón, La Delicia, Tumbaco y Los Chillos (14).

Uno de los efectos de la conversión a distrito metropolitano es la visibilidad del carácter regional de su dinámica económica. No se trata en sí mismo de un fenómeno nuevo, sino de la posibilidad de volver a enfocar el carácter regional, intrínseco al devenir histórico de la economía quiteña, que de algún modo quedó reducido o fragmentado transitoriamente por un tratamiento circunscrito a delimitaciones cantonales o urbanas que, en el mejor de los casos, señalaba como "área de influencia” el alcance del poder económico en términos de propiedad, flujos e interrelaciones que, desde su fundación misma, caracterizan a Quito.

En esta perspectiva regional, como se anotó anteriormente, el Plan Equinoccio 21 Quito hacia el 2025, del segundo período de Moncayo, destacó a Quito como “ciudad-región”, poniendo el acento en sus proyecciones como espacio de innovación con carácter industrial y empresarial. Su trama regional se presenta como condición para la ciudad "productiva y competitiva", esbozada como propuesta de mediano plazo.

Posteriormente, el Plan Metropolitano de Desarrollo 2012-2022 también caracterizó a Quito como “ciudad-capital, distrito-región”, cuya estructura territorial abarca tres ejes de desarrollo: "el eje norte, que incluye Cayambe, el nodo Ibarra-Otavalo, y el nodo Tulcán-Ipiales; el eje sur, Latacunga-Salcedo-Ambato; y el eje oeste, el nodo Santo Domingo de los Tsáchilas, que constituyen aglomeraciones locales intermedias" (21).

Con estos conglomerados urbanos se dan relaciones funcionales, esto es: "flujos de personas, bienes y servicios articulados con los sectores productivos y reproductivos: el abastecimiento y procesamiento de alimentos, el suministro de materia prima y partes para la manufactura y los sistemas de comercialización de bienes nacionales e importados" (22). A su vez, el distrito metropolitano brinda al conjunto de la región: "servicios administrativos relacionados con las dependencias del Gobierno nacional; genera empleo y provee equipamientos comerciales, 
logísticos, educativos, de salud, recreativos y culturales regionales, nacionales e internacionales" (22).

El distrito metropolitano no solo permitió ver la economía en sus alcances regionales sino consolidarla, al dinamizar y fortalecer sus rasgos en términos de concentración de la propiedad, afianzamiento de su esquema sectorial, de su importancia relativa a nivel nacional y de su dinámica poblacional. Una economía regional largamente configurada desde la hegemonía de los poderes regionales quiteños quedó amparada en un explícito marco metropolitano orientado a la competitividad, que asimila los intereses y formatos empresariales a los de la ciudad como un todo.

El distrito metropolitano se va despojando de la condición de una capital política que no llegaba a ser capital económica del país —rol atribuido antes a Guayaquil—, para asumir el estatus de la zona más avanzada en términos de los "capitales" y condiciones que le permitirían ser ese territorio competitivo prefigurado, como se han empeñado en mostrar las sucesivas administraciones municipales.

Los aspectos relevantes en la trayectoria reciente de Quito, en la perspectiva del proyecto de modernización y globalización que preside su conversión en distrito metropolitano, fueron destacados por Manuel Chiriboga:

desde inicios de la década de 1990, la capital de Ecuador se convirtió, entre otros, en un centro económico importante para nuevas exportaciones, presencia de empresas transnacionales y de centros de postgrado en diversos campos de renombre regional. Pero tal vez la obra de cambio más importante tiene que ver con su propuesta de transformación productiva e inserción global de Quito. Ello tiene que ver con infraestructura: el nuevo aeropuerto de Tababela, la transformación del centro histórico de la ciudad para convertirlo en un símbolo de la ciudad, tanto hacia sus ciudadanos, como también en la imagen hacia afuera, la multiplicación de espacios culturales (museos, teatros y centros para artes de interpretación y medios audiovisuales), desarrollo de infraestructura de acceso al Pichincha por medio de un teleférico, e impulso a la infraestructura hotelera y gastronómica de la ciudad. A ello hay que añadir las acciones dirigidas a impulsar la actividad productiva con el establecimiento de Conquito y el Plan Equinoccio para el desarrollo económico de la ciudad. (2009, 14-5) 
En términos más generales algunas evidencias se desprenden de los resultados del Censo Económico de 2010, así como del Censo de Población y Vivienda de ese mismo año, ambos de nivel nacional. En el distrito metropolitano se ubicaron en ese año censal el $18 \%$ de la población nacional, 2239191 habitantes, y el 20 \% de los establecimientos económicos, esto es la importante cifra de 101937 unidades (INEC 2010).

$\mathrm{Su}$ estructura, sin embargo, es claramente polarizada: considerando el nivel de ventas, la abrumadora mayoría de establecimientos se clasifica como microempresas — 87 491, con ventas inferiores a $100 \mathrm{mil}$ dólares anuales_-, mientras en el otro extremo se ubican 956 unidades grandes, cuyas ventas superaron los 5 millones en el año de referencia. Del punto de vista del empleo también prevalece la polarización, pues mientras hay 314 empresas que se consideran grandes al tener 200 o más personas empleadas, 93406 microempresas tienen como máximo diez personas. En conjunto, generan el $27 \%$ del empleo nacional (2010).

Esto forma parte de una tendencia a la concentración que no es, por supuesto, un rasgo exclusivo de la economía regional quiteña, sino una característica nacional, así, según Larrea y Greene (2015): “Las 100 mayores empresas concentran el 36,5\% del ingreso total, el $1 \%$ más alto (244 empresas) concentra el 50,8 \% del ingreso total, y el primer decil (2 442 mayores empresas) alcanza el 85,9 \% del ingreso total” (25).

En esta modalidad de concentración de los ingresos a nivel empresarial, Pichincha ocupa, justamente, el primer lugar con el 50,3\%, seguida por Guayas con el 37,3 \%, y muy de lejos por Azuay con el 4,8 \% y Manabí con el 2,6 \% (27). Igual ocurre con la concentración del patrimonio de las empresas: 54 \% en Pichincha, 30 \% en Guayas, 7,4 \% en Azuay, 3,4 \% en Tungurahua y 1,2 \% en Manabí (28).

Otra dimensión relevante de la concentración tiene que ver con las actividades consideradas de alta productividad que, nuevamente, tienen mayor presencia y generan más ingresos en Pichincha, esto es el 50,3 \%, mientras en Guayas es del 37,3 \% (28-9). En lo que va del siglo, distintos rankings empresariales — basados en general en información de la Superintendencia de Compañías - sitúan de modo sistemático a la Corporación Favorita S. A., de origen quiteño, como la más grande del país en 
cuanto a ventas. Esta supera a empresas públicas en ámbitos estratégicos como energía y telecomunicaciones, así como a grandes empresas transnacionales de la construcción, minería, alimentación u otras.

El DMQ se considera "el centro financiero de Ecuador", con 818 establecimientos que representan el $24 \%$ del sector actividades financieras y de seguros, el $40 \%$ del personal ocupado y el $37 \%$ de los ingresos por ventas y servicios. Este sector no escapa a las tendencias de polarización señaladas para el país y la región. Así, del punto de vista del empleo generado predominan las microempresas ( 1 a 9 empleados) con el $66 \%$, en tanto solo el $2 \%$ se clasifica como grande (más de 200 personas empleadas) (Instituto de la Ciudad 2013, 9-18).

Es en este último segmento donde se ubican entidades como el Banco Pichincha, que se ha mantenido como el más grande del país, y otros como Produbanco y la sociedad financiera Diners Club del Ecuador que escalaron posiciones en el período, lo cual indica también la importancia relativa del sector financiero en la economía regional y su irradiación a nivel nacional, máxime si en el esquema empresarial y corporativo adoptado la inversión se considera variable clave: "el $41 \%$ de la inversión total realizada en el Ecuador en el año 2010 fue US \$ 938 millones y tuvo como destino Quito, lo cual muestra las condiciones favorables que ofrece el Distrito a la inversión” (MDMQ 2012, 17).

En el período intercensal 2001-2010 se mantuvieron como principales ramas de actividad en cuanto a ocupación, en su orden: comercio al por mayor y menor (25\%), e industrias manufactureras (12\%), pero el crecimiento relativo de comercio al por mayor y menor fue mucho más notable que el de las industrias manufactureras que alcanzaron tasas del 41,06 \% y 24,44 \%, respectivamente. La rama más dinámica en ese período fue alojamiento y servicio de comidas, que creció a una tasa del $116,93 \%$, si bien se ubica en un sexto lugar con $8 \%$ del empleo. Las actividades de enseñanza con el $11 \%$ del empleo y de administración pública y defensa con el $9 \%$ son también importantes.

De manera coincidente, dos sectores generan más de dos tercios del volumen de ventas: en primer lugar el comercio al por mayor y menor, con 37 \%, seguido de las industrias manufactureras, con el $34 \%$. Las 
dos principales fuentes de empleo se ubican en las ramas de comercio y manufactura, con el $24 \%$ y $13 \%$, respectivamente. La importancia de la manufactura destaca porque representa el $24 \%$ de los ingresos por ventas. En términos sectoriales, representa el $30 \%$ del empleo nacional en esta rama, $34 \%$ de ventas nacionales, pertenecen el $34 \%$ de grandes empresas manufactureras, alrededor de 150 empresas que generan el $31 \%$ de todo el ingreso por ventas del sector (Instituto de la Ciudad 2013, 13).

El distrito metropolitano también despuntó en el rubro de agroexportación, especialmente de flores. En Pichincha se ubica el $66 \%$ de la superficie total destinada a la floricultura en el país, que alcanza alrededor de seis mil hectáreas, área que sigue creciendo a razón de $13 \%$ anual (Chiriboga 2009, 56). Los elementos de afinidad de este sector con el proyecto modernizador en ciernes se vinculan con su orientación exportadora y con los niveles de inversión y tecnología involucrados.

El fenómeno de concentración tiene variados matices y, de cara al proyecto de territorio competitivo, ha sido valorado en términos positivos en los distintos planes metropolitanos. Una de esas facetas tiene que ver con el peso relativo del empleo por sectores, pues Quito concentra más del $25 \%$ del empleo nacional en 11 de las 20 ramas de actividad contempladas en el Censo de 2010, en unos casos incluso alrededor del $50 \%$, construcción $53,7 \%$, actividades profesionales, científicas y técnicas $49,7 \%$, y actividades de organizaciones y órganos extraterritoriales 49,3 \% (Instituto de la Ciudad 2012, 10). El Plan Equinoccio 21 enfatiza que el DMQ es el polo de desarrollo industrial andino del país:

Concentra más de $65 \%$ del número de establecimientos fabriles, del personal ocupado, de la producción total y de la inversión de capital. Básicamente en actividades de punta y especialmente de la industria textil, metalmecánica y de acero, de productos químicos y farmacéuticos, editorial y artes gráficas (en el DMQ se produce el $80 \%$ de los libros que se publican en el país), de la agroindustria relacionada con las exportaciones de flores, vegetales exóticos, cárnicos y lácteos y, en menor proporción, el procesamiento de aceite de palma, producción avícola y de licores. (MDMQ 2004, 10) 
En igual sentido el plan destaca que el distrito metropolitano concentra: "el $65 \%$ de las fábricas existentes en el Ecuador; el $31 \%$ de las firmas registradas en la Superintendencia de Compañías a nivel nacional. El $42 \%$ del patrimonio productivo, el $45 \%$ de los empleados y el $41 \%$ de los ingresos empresariales del país" (22). En torno a la innovación de matriz empresarial, en el Censo Económico de 2010 se constató la mejor posición relativa de Quito, pero en un marco de ínfima inversión en investigación y desarrollo como tendencia nacional:

las empresas grandes y medianas invirtieron por cada US \$ 100 en activos fijos menos de 1 centavo en I\&D; y que Quito concentró el 92\% de esa inversión nacional (US \$ 152 millones) en este grupo de empresas; con un gasto de apenas 1,7 centavos por cada US \$ 100 de activos fijos. (Instituto de la Ciudad 2012, 21)

Quito ocupa también el primer lugar en el acceso a servicios básicos e infraestructura que remite, al mismo tiempo, a cobertura de derechos básicos de la población y a condiciones para la buscada competitividad sistémica. Entre 2001 y 2010 el acceso a agua potable mediante red pública pasó del 91,06 \% al 96,03 \%, la conexión a red pública de alcantarillado del 83,4 \% al 90,9 \%, el servicio de luz eléctrica llegó al 99,4 \%. En comparación con Guayaquil, la brecha más notable se da en alcantarillado, pues en esa ciudad solo llega al 60,65 \% de las viviendas.

Otra de las dimensiones que suele destacarse es el acceso a tecnologías de información y comunicación. En el caso de internet, a 2009 la tasa de penetración nacional fue del $10 \%$, Quito tuvo el $42 \%$ de los usuarios, Guayaquil el $24 \%$, y en el resto del país se repartía el 34 \% (Chiriboga 2009, 34). En ese mismo año Quito estaba también en primer lugar en cuanto al uso de internet en los establecimientos económicos, con 17,3 \%, seguida de Cuenca con el 16,7 \%, en tanto Guayaquil llegó apenas al 9,9\% (INEC 2010). Las principales definiciones y visiones para la economía del DMQ ponen el acento en estas características del segmento "grande" a nivel empresarial, de inversiones y de lo que se considera alta tecnología. Así, el Plan Equinoccio 21 identificó lo siguiente:

Durante las últimas décadas la economía del DMQ ha consolidado su influencia regional y ha diversificado la producción y los servicios, con 
una parte de la producción local orientada hacia el mercado internacional. Estos procesos han derivado en la conformación de una base productiva que puede constituirse en la plataforma para enfrentar los retos de la globalización, siempre y cuando se produzcan cambios cualitativos en la productividad y competitividad de la industria y los servicios (MDMQ 2004, 10-1).

Con tal propósito, este plan se propuso impulsar una "cultura de la innovación, calidad y eficiencia” (10), en el conjunto de la sociedad, y estableció que frente al objetivo central de alcanzar competitividad, el municipio tiene corresponsabilidades en la creación de un entorno favorable, garantizando la seguridad jurídica, ordenando el territorio, construyendo la infraestructura, facilitando la movilidad, suministrando el equipamiento de servicios, apoyando la creación de capital social, fortaleciendo los mercados financieros y laborales, y auspiciando el desarrollo científico y tecnológico.

Mientras tanto, la gran mayoría de unidades económicas que, en la matriz de polarización imperante, se ubican en la escala "micro", no figuran desde las potencialidades, son tratadas, en general, como parte de un problema de informalidad a ser superado. Así, por ejemplo, se ha establecido que $26,9 \%$ de las denominadas microempresas no cuentan con el Registro Único de Contribuyentes (RUC), mecanismo que permite tanto la retención como el pago de impuestos fijados para el conjunto de transacciones económicas. Para el caso de las unidades pequeñas, medianas y grandes, esta carencia es mínima, pues solo involucra al $1,9 \%$ y $0,2 \%$ de los casos en su orden. Tal problema de "informalidad" es sin embargo menor al promedio nacional, pues a esa escala el $33 \%$ de establecimientos carece de RUC (Instituto de la Ciudad 2012, 6-7).

Las microempresas representan el 93,8\% del total de establecimientos económicos del DMQ, pero solo perciben el $16 \%$ de los ingresos, mientras en el otro extremo el $0,3 \%$ de los establecimientos son grandes y concentran el $48 \%$ de los ingresos.

las microempresas más comunes dentro del DMQ son las dedicadas a Venta al por menor en comercio no especializado con predominio en la venta de alimentos, bebidas o tabaco, con 15\%; Actividades de restaurantes y servicios de comida, con $10 \%$; y Venta al por menor de prendas 
de vestir, calzado y artículos de cuero en comercio no especializado, con $7 \%$. Estas tres actividades están directamente relacionadas con las tiendas de barrio, los restaurantes y los almacenes de ropa.

En este sentido el Plan Metropolitano marca cierta diferencia o inflexión al plantear el eje económico como "Quito productivo y solidario", proponiendo: "fortalecer el enfoque de pleno empleo, una economía diversificada, tanto en distintas ramas productivas como en la tipología y el tamaño de los emprendimientos” (MDMQ 2004, 20). Sin embargo, el acento sigue colocado en la economía grande: "El DMQ está marcado por una visión ambiciosa pero posible: ser reconocido como capital productiva en red del país; una ciudad-región con actores de nivel mundial, que fomente un modelo emprendedor, innovador, exportador, con valor agregado, institucional y socialmente equitativo" (77).

Este plan, haciéndose eco de las novedosas definiciones constitucionales en la materia, nombra y reconoce la importancia de la economía popular y solidaria. Identifica que alrededor del $14 \%$ de la población ocupada del distrito se encuentra en este sector, especialmente en actividades de comercio al por menor, alojamiento y comidas, y plantea que "los lineamientos de políticas deberán considerar estas particularidades y promover su integración a cadenas mayores y menores, su sustentabilidad social y su desarrollo desde las lógicas más diversas” (79). Se introduce así, al menos en breve referencia, la noción de diversidad en el terreno económico que, en cambio, había sido ya asumida en el tratamiento de las dimensiones social y cultural.

En el período intercensal 2001-2010, Quito se ubicó en tercer lugar en términos de crecimiento poblacional, con una tasa del $22 \%$ (delante están Santo Domingo con 28 \% y Loja con 23 \%). Un crecimiento absoluto de alrededor de 400 mil habitantes que se explica por la conjunción del crecimiento demográfico con apreciables niveles de migración tanto interna como externa: el 34,9 \% de sus habitantes nació en otros lugares fuera de Quito.

La migración marca, asimismo, un relativo envejecimiento de la pirámide poblacional, pues a Quito llega una proporción mayor de personas jóvenes y adultas por razones de trabajo y estudio. El DMQ se man- 
tiene como un polo de atracción de población migrante, que se reforzó ligeramente entre 2001 y 2010, pues la proporción de población nacida en Quito disminuyó del 67,8 \% al 65,1 \%, en tanto la población de otros orígenes pasó del 32,2 \% al 34,9 \% (Instituto de la Ciudad 2012, 13).

Esta tendencia se combinó con un fenómeno nuevo en cuanto a sus proporciones, esto es la emigración, causada en buena medida por la crisis económico-financiera de 1999-2000. El Censo de 2010 registró la emigración de 57265 personas que, siguiendo la tendencia de esa ola migratoria nacional, se dirigieron principalmente a España (50 \%), mientras $19 \%$ partió hacia Estados Unidos (13).

Es posible observar cómo la emigración hacia España es mayor desde las zonas más empobrecidas del DMQ, tales los casos de Quitumbe y Calderón, cuyos flujos a ese destino fueron del 67,8 \% y $60 \%$, respectivamente. También resultó novedoso en el período intercensal el flujo migratorio de estudiantes hacia destinos como Argentina, Alemania y Canadá, siguiendo también un patrón de origen diferenciado en la ciudad, pues estos provenían desde las zonas de las administraciones zonales Eugenio Espejo y Tumbaco.

Resulta inherente al carácter regional de la economía el desborde de las distinciones entre áreas urbana y rural, lo que relativiza tal carácter en las 33 parroquias clasificadas como rurales respecto de las 32 urbanas, en un área total del DMQ que abarca una superficie de $4235,2 \mathrm{~km}^{2}$.

Zonas consideradas formalmente aún como rurales son, en los hechos, lugares de vivienda con altas concentraciones demográficas y pautas netamente urbanas de uso del suelo, de consumo y de vida, en combinación con espacios de ubicación de industrias o unidades productivas de perfil asimismo urbano. De ahí que uno de estos sitios, la parroquia rural de Calderón, sea la de mayor crecimiento en población en el último período intercensal, con el notable porcentaje de $78 \%$.

Esta realidad se presenta como inevitable y acaso como parte de un proceso deseable de subordinación a la ciudad. Por ejemplo, desde el Instituto de la Ciudad se consideraba que

Los derechos agrarios se integran funcionalmente a los derechos urbanos como partes del territorio. Las ciudades son también responsables 
del desarrollo armónico, integral y sostenible; de las garantías a la función social, económica y productiva de la tierra en sus entornos; del acceso a los recursos, mediante dotación a los campesinos pobres y mediante el mercado para la empresa; y, de la eficiencia en la función social, económica y productiva de la propiedad. (Chiriboga 2009, 11)

Así, en este sector "rural" vive el 27 \% de la población económicamente activa (PEA), pero la población efectivamente ocupada en las parroquias rurales llega solo al $11 \%$ (Instituto de la Ciudad 2012, 21), lo que indica su condición predominante de zonas de vivienda para población que debe desplazarse hacia los lugares de trabajo o actividad económica ubicados en otros lugares del DMQ, con las consiguientes implicaciones en cuanto a movilidad y transporte, uno de los temas crecientemente críticos.

La zona norte de la ciudad es, por así decir, el polo laboral, pues en el área correspondiente a la Administración Zonal Eugenio Espejo trabaja el 52 \% de las personas ocupadas, en tanto ahí vive $20 \%$ de los habitantes (12). Considerando el crecimiento del número de viviendas por zonas, podría hablarse de una suerte de invasión desde la ciudad a las zonas rurales: en el período intercensal 1990-2001 el número de unidades se incrementó en $49 \%$ en el área urbana y en $101 \%$ en la rural, tendencia que continuó en el siguiente período 2001-2010, con incrementos del 29,83 \% y 61,09\%, respectivamente (MDMQ 2012, 63). Miles de nuevas viviendas han reconfigurado el espacio de manera radical, cumpliendo de algún modo la premisa de que lo urbano abre paso a lo global, a la forma de modernización a la que aspiraron las recientes administraciones municipales (Chiriboga 2009).

Estas cifras muestran el boom inmobiliario que se ha producido en el período intercensal y más allá, y explican, de paso, por qué más de la mitad de las personas ocupadas en la construcción a nivel nacional trabajan en Quito. Otra de las facetas de este gran crecimiento urbano es la existencia de centenares de barrios "de hecho" o no regularizados, con problemas tanto en términos de acceso a servicios como de sus condiciones legales. La Unidad Regula tu Barrio, creada para atender esta problemática, legalizó algo más de 150 barrios en poco más de dos años, 
proceso que continuó para atender alrededor de 600 casos identificados (Instituto de la Ciudad 2013, 6).

A 2010, Quito ocupaba el primer lugar del país en cuanto a población que vive en departamento (33\%), proporción que habrá sin duda aumentado desde entonces con la salida del aeropuerto, cuya localización al interior de la ciudad limitaba la construcción en altura. A bastante distancia, el $14 \%$ de la población en Ambato y el $13 \%$ en Guayaquil y Cuenca optaron por una vivienda de ese tipo. Este rasgo considerado de modernidad urbana se reforzó en el período intercensal considerado, pues pasó del 26,5 \% al $33 \%$.

También Quito se situó en el primer lugar de viviendas arrendadas (39\%), tendencia que se vincula con la presencia de población migrante y las condiciones del mercado inmobiliario. Los niveles de arrendamiento en el Centro Histórico son aún mayores, pues superan el $60 \%$. Desde la convencional perspectiva de "capital humano", una de las condiciones para el proyecto de innovación, productividad y competitividad enarbolado, en 2010 Quito presentó el más alto perfil de niveles de instrucción de la población del país, la población con niveles superior y de posgrado se ubica en el $22,5 \%$ y $2,4 \%$, respectivamente, seguida de Cuenca con el 18,9 \% y 1,9 \%, mientras Guayaquil llega al $16,6 \%$ y 1,1 \%. Considerando la población ocupada, el nivel de escolaridad promedio en el DMQ es de 12,45 años, el más alto en el país, excluyendo Galápagos (9).

De un total de 2235 instituciones educativas, el $60 \%$ son particulares y el $40 \%$ públicas. El $52 \%$ de la población estudiantil del DMQ asiste a centros educativos fiscales, el $42 \%$ a privados, el 3,2 \% a municipales y el $3 \%$ a fiscomisionales (MDMQ 2012, 41). La más alta proporción de entidades privadas educativas se explica en parte por el señalado crecimiento "irregular" de zonas periféricas, hacia las cuales la oferta pública tarda más en llegar.

Quito ha sido el cantón con menor incidencia relativa de la pobreza y la pobreza extrema, condición que ha mantenido en el tiempo, aunque en este campo no hay necesariamente un punto de no retorno, podrían ocurrir regresiones. En el período intercensal ambas propor- 
ciones se redujeron coincidiendo con una tendencia nacional, pero de manera más acentuada, pues a nivel nacional la pobreza se redujo en 11 puntos mientras en Quito en 14. No obstante, dado el tamaño de su población, es el segundo cantón con mayor número de personas en situación de pobreza (660 mil), superado por Guayaquil con 1,1 millones de personas (Instituto de la Ciudad 2013, 4).

Ha sido recurrente en los diagnósticos y propuestas hacer una asociación entre "informalidad" y empobrecimiento, de la que se desprende como natural solución o salida la formalización que, según esa perspectiva, tendría efectos positivos múltiples. A nivel nacional, 44,1\% de las personas ocupadas trabaja en el definido como sector informal, en el caso del distrito metropolitano 34,7 \%, de los cuales 14,3\% eran pobres. Matizando las lecturas mencionadas, en algunos acercamientos al tema desde la administración municipal del alcalde Barrera, se constató que informalidad y pobreza no son sinónimos, y que bajo esa denominación existe una heterogeneidad de unidades económicas que ameritan ser vistas en sus especificidades (Instituto de la Ciudad 2012, 14).

Otra asociación recurrente ha sido la de trabajo por cuenta propia e informalidad, enfoque que ha prevalecido sin mayores cambios en la visión metropolitana, pues $47,6 \%$ de la población del DMQ trabaja por cuenta propia y es potencialmente informal (15). Los niveles de desocupación se ubican por debajo de la media nacional, $4,9 \%$ y $6 \%$, respectivamente.

Pero hay grupos en que los niveles de desocupación, por el contrario, superan esa media nacional de desempleo: negros, afroecuatorianos y mulatos están afectados en proporciones del 7,8 \%, 6,9 \% y 6,2 \% (13). Son estas las condiciones y tendencias que, de alguna manera, han pasado a ser parte del proyecto de "modernización y globalización” de Quito que, no obstante su enfoque predominantemente empresarial y de mercado, se ha considerado "ante todo un proyecto del Gobierno Metropolitano, con una base amplia de apoyo en los sectores populares y medios".

Los grupos empresariales lo han comprado a medias, mientras algunos empresarios, especialmente en el sector turístico y algunos ligados a la innovación empresarial y tecnológica lo han hecho con entusiasmo, y se han abanderado de la propuesta de transformación de la 
ciudad; otros, tal vez los más, han acompañado el proceso a regañadientes y sin entusiasmo. Aún más, parte de la cultura empresarial serrana, pero también de muchos de los grupos corporativos y profesionales, se caracteriza por la débil coordinación y el regateo de las políticas (Chiriboga 2009, 18). A su manera, el municipio y el distrito metropolitano habían entrado en la ruta de la ciudad-región competitiva.

En síntesis, con la puesta en vigencia de la normativa metropolitana desde al año 1993, el municipio capitalino al tiempo que procedió con la conversión del cantón en distrito metropolitano modernizó su estructura organizacional, acentuando la institucionalidad empresarial y descentralizada con un trust de empresas, corporaciones y fundaciones municipales, junto con una red de administraciones zonales y delegaciones desconcentradas en el territorio distrital, con las que provee infraestructura, bienes, equipamiento, servicios públicos, así como implementa las políticas metropolitanas. El arreglo institucional híbrido de Estado local y empresas municipales es afín con el espíritu jerárquico y elitista del modelo metropolitano, y consolidó la tendencia de creciente colonización del mundo privado a la esfera pública local.

Las narrativas de los planes urbanos quiteños arguyeron sucesivamente una misma orientación estratégica hacia la modernidad metropolitana, no fueron relatos de ciudades imaginadas sino promesas de búsqueda del orden regulatorio, ante la desordenada e incontrolada expansión urbana acaecida en las últimas décadas del siglo XX y continuada en las primeras del siguiente, por la que la "ciudad compacta" asentada en la meseta de Quito, se desparramó hacia los valles circundantes provocando conurbanos, arrinconando a las comunas y áreas campesinas. En el proceso metropolitano Quito se convirtió en la ciudad de mayor dinamismo económico, pues en el distrito se concentra el 45 \% del PIB del país, reproduciéndose, no obstante, condiciones de segregación urbana, estigmatización cultural e inferioridad de la pobreza, la que también se desperdigó por el distrito metropolitano.

La acción colectiva de los sectores populares, barriales y subalternos de la urbe sobrevino en una geografía menor del distrito metropolitano, ocurrió en el perímetro de los barrios periféricos dentro de la 
ciudad, en los microespacios públicos del centro norte y del extremo sur, en los que surgieron las propuestas populares de orden urbano. Su comprensión implica el análisis de las luchas urbanas acaecidas en una escala espacial menor dentro de la ciudad, cuestión que será tratada en la segunda parte referida a la contestación social, en la que examinaremos el movimiento barrial quiteño, la acción de los grupos subalternos y las movilizaciones de las clases medias y acomodadas de la capital. 